\title{
Loss of Tumor Suppressor Gene Function in Human Cancer: An Overview
}

\author{
Li-Hui Wang $^{\mathrm{a}} \quad$ Chun-Fu Wu $\quad$ Nirmal Rajasekaran ${ }^{\mathrm{b}} \quad$ Young Kee Shin ${ }^{\mathrm{b}, \mathrm{c}, \mathrm{d}}$ \\ aDepartment of Pharmacology, Shenyang Pharmaceutical University College of Life Science and \\ Biopharmaceutical, Shenyang, China, ${ }^{b}$ Research Institute of Pharmaceutical Science, Department of \\ Pharmacy, Seoul National University College of Pharmacy, Seoul, 'Center for Anticancer Companion \\ Diagnosis, Logone Bioconvergence Research Foundation, Seoul, dDepartment of Molecular Medicine \\ and Biopharmaceutical Sciences, Graduate School of Convergence Science and Technology, Seoul \\ National University, Seoul, South Korea
}

\section{Key Words}

Tumor suppressor gene • Ubiquitination • Cellular localization • Transcriptional regulation

\begin{abstract}
Cancer is a disease caused by the accumulation of genetic and epigenetic changes in two types of genes: tumor suppressor genes (TSGs) and proto-oncogenes. Extensive research has been conducted over the last few decades to elucidate the role of TSGs in cancer development. In cancer, loss of TSG function occurs via the deletion or inactivation of two alleles, according to Knudson's two-hit model hypothesis. It has become clear that mutations in TSGs are recessive at the level of an individual cell; therefore, a single mutation in a TSG is not sufficient to cause carcinogenesis. However, many studies have identified candidate TSGs that do not conform with this standard definition, including genes inactivated by epigenetic silencing rather than by deletion. In addition, proteasomal degradation by ubiquitination, abnormal cellular localization, and transcriptional regulation are also involved in the inactivation of TSGs. This review incorporates these novel additional mechanisms of TSG inactivation into the existing two-hit model and proposes a revised multiple-hit model that will enable the identification of novel TSGs that can be used as prognostic and predictive biomarkers of cancer.

\section{Introduction}

(C) 2018 The Author(s) Published by S. Karger AG, Basel

Many genetic studies in different cancers have identified a small number of genes that must be mutated or altered to promote the growth of malignant cells [1]. The two main properties of cancer cells, uncontrolled cell growth and the ability to invade other tissues, are the result of these genetic and epigenetic alternations. Genetic alternations include genetic mutations, genomic instability, loss of heterozygosity ( $\mathrm{LOH}$ ), and gene copy number variation
\end{abstract}

Young Kee Shin and Nirmal Rajasekaran
Research Institute of Pharmaceutical Science, Department of Pharmacy, Seoul National University College of Pharmacy, Seoul (Korea)

Tel. +82-2-880-9126, E-Mail ykeeshin@snu.ac.kr; nirmalpharma@gmail.com

\section{KARGER}


(CNV). By contrast, epigenetic changes include histone modifications, DNA methylation, and loss of imprinting (LOI). These modifications regulate gene expression without altering the underlying nucleotide sequence [2-4].

In general, cancer-related genes can be divided into two broad classes, proto-oncogenes and tumor suppressor genes (TSGs). Proto-oncogenes are generally involved in pathways that promote cellular growth. These genes can cause normal cells to become cancerous when they are activated by mutations or alterations. Mutations in proto-oncogenes are typically dominant in nature, and the mutated versions of these genes are known as oncogenes [5]. TSGs is considered as another kind of crucial genes, which are involved in DNA damage repair, inhibition of cell division, induction of apoptosis, and suppression of metastasis. Therefore, loss of TSGs function would result in the onset and progression of cancer [6]. Previous study showed one copy of a TSG is sufficient to control cell proliferation; therefore, both alleles of a TSG must be permanently inactivated or lost to result in tumor development [7]. Additionally, some genes can act as both proto-oncogenes and TSGs, depending on context. TSGs are broadly classified into five types: 1) Genes encoding intracellular proteins, that control progression into a specific stage of the cell cycle (e.g., pRB and p16) [8]; 2) Genes encoding receptors or signal transducers for secreted hormones or developmental signals that inhibit cell proliferation [e.g., transforming growth factor (TGF)- $\beta$ and adenomatous polyposis coli (APC)] [9]; 3) Genes encoding checkpoint-control proteins that trigger cell cycle arrest in response to DNA damage or chromosomal defects [e.g., breast cancer type 1 susceptibility protein (BRCA1), p16, and p14] [10]; 4) Genes encoding proteins that induce apoptosis (e.g., p53) [11]; and 5) Genes encoding proteins involved in repairing mistakes in DNA [e.g., p53 and DNA mismatch repair protein 2 (MSH2)] [12].

TSG inactivation is a common mechanism contributing to the development of cancer. Molecular studies show that inactivation of TSGs is commonly associated with cytogenetically undetectable microdeletions that were identified by demonstrating LOH of polymorphic markers that map within or near tumor suppressor loci [13]. Germline mutations in TSGs account for most known heritable forms of cancer, because somatic inactivation of one allele is usually compatible with normal development [14]. In addition, promoter methylation also contributes to the inactivation of TSGs $[15,16]$. Most of the TSGs discovered to date follow the above Knudson paradigm (Table 1). These TSGs are recessive at the cellular level, and both alleles are deleted, mutated, or silenced by methylation in cancer. However, there is increasing evidence from studies of human tumor specimens that functional inactivation of TSGs by cellular mechanisms such as proteasomal degradation, abnormal cellular location, and transcriptional regulation can also contribute to tumorigenesis. This review provides

Table 1. Location and function of tumor suppressor genes

\begin{tabular}{lccc}
\hline Gene & Familial cancer syndrome & Function & Chromosomal location \\
\hline TP53 & Li-Fraumeni syndrome & Cell cycle regulation, apoptosis & $17 \mathrm{p} 13.1$ \\
RB1 & Familial retinoblastoma & Cell cycle regulation & $13 \mathrm{q} 14.1-\mathrm{q} 14.2$ \\
p16(INK4a) & Familial melanoma & Cell cycle regulation & $9 \mathrm{p} 21$ \\
p14(ARF) & Familial melanoma & Mdm2 antagonist & 9p21 \\
CHK 1/2 & Li-Fraumeni syndrome & Protein kinase (G1 control) & $22 \mathrm{q} 12.1$ \\
KLF6 & Unknown & Transcriptional regulation & $10 \mathrm{q} 21-\mathrm{q} 22$ \\
NF1 & Neurofibromatosis type I & Catalysis of RAS inactivation & $17 \mathrm{q} 11.2$ \\
APC & Familial adenomatous polyposis & Inhibition of signal transduction & $5 \mathrm{q} 21-\mathrm{q} 22$ \\
TSC1 & Tuberous sclerosis 1 & Interaction with tuberin & $9 \mathrm{q} 34$ \\
DCC & Deleted in colorectal carcinoma & Transmembrane receptor & $18 \mathrm{q} 21.3$ \\
BRCA1 & Familial breast cancer & Cell cycle, DNA repair & $17 \mathrm{q} 21$ \\
MSH2 & HNPCC1 & DNA mismatch repair & $2 \mathrm{p} 22-\mathrm{p} 21$ \\
MLH1 & HNPCC2 & DNA mismatch repair & $3 \mathrm{p} 21.3$ \\
PTEN & Cowden syndrome & PI-3 kinase signal transduction & $10 \mathrm{q} 23.3$ \\
LKB1 & Peutz-Jeghers syndrome & Phosphorylation and activation of AMPK & $19 \mathrm{q} 13.3$ \\
CDH1 & Familial diffuse gastric cancer & Cell-cell adhesion protein & $16 \mathrm{q} 22.1$ \\
TGF-R I & Unknown & Growth inhibition & $9 \mathrm{q} 22.33-\mathrm{q} 31.1$ \\
TGF-R II & Unknown & Growth inhibition & $3 \mathrm{p} 24.1$ \\
SMAD4 & Familial juvenile polyposis syndrome & Regulation of TGF- $\beta /$ BMP signaling & $18 \mathrm{q} 21.1$ \\
SMAD2 & Juvenile polyposis & TGF- $\beta$ signal transduction & $18 \mathrm{q} 21.1$ \\
\hline
\end{tabular}


an overview of the inactivation mechanisms of known TSGs that do not follow the classic Knudson two-hit hypothesis. Molecular analysis of these TSGs may reveal novel targets for specific sub-classes of cancer.

\section{The ubiquitin-proteasome degradation pathway}

Cellular levels of proteins encoded by TSGs and oncogenes must be critically regulated to prevent carcinogenesis and malignant progression. Levels of TSG products are often controlled by the ubiquitin-proteasome pathway, a specific cellular proteolysis mechanism. E3 ubiquitin ligases catalyze the polyubiquitination of their specific protein substrates by cooperation with the ubiquitin-activating enzyme E1 and the ubiquitin-conjugating enzyme E2, and then the modified substrates are degraded by the 26S proteasome [17]. Enhanced degradation of TSG products due to dysfunction of the ubiquitination-proteasome pathway or aberrant expression of E3 ligases may be associated with tumorigenesis. As an example, inactivation of TSG function via ubiquitin-proteasomal degradation is discussed below.

\section{Inactivation of p53 TSG (TP53) by ubiquitin-proteasomal degradation}

The p53 TSG (TP53) is inactivated in the majority of cancers $[18,19]$. It negatively regulates the cell cycle and is involved in genomic stabilization and angiogenesis $[18,19]$. Inactivation of TP53 by homozygous deletion (HD), $\mathrm{LOH}$, point mutations, and/or methylation has been frequently reported in human cancers (Table $2-9$ ). In addition to these genetic inactivation mechanisms, the cellular p53 level is also regulated through ubiquitinationmediated degradation [20]. A number of RING finger domain-containing E3 ligases, including mouse double minute 2 homolog (MDM2), MDM4, herpesvirus-associated ubiquitin-specific protease (HAUSP), constitutively photomorphogenic 1 (COP1), Pirh2, and ARF-BP1, can ubiquitinate p53 [21-25]. However, MDM2 appears to be the dominant regulator, as the lethality of MDM2 deficiency can be rescued by the loss of TP53 [21, 26]. The E3 ligase activity of MDM2 towards p53 is significantly increased by heterodimerization with MDM4 $[21,26]$. Gene amplification of MDM2 was observed in approximately $10 \%$ of tumors [21, 26], most of which retained wild-type TP53. In some tumor cells, overexpression of MDM2 occur even in the absence of MDM2 gene amplification [27]. Additionally, overexpression of

Table 2. The expression and inactivation mechanisms of tumor suppressor genes in leukemia and brain cancer. Note: "-"no report found; "HD" homozygosity deletion; "NS" no significant difference; the average percent was calculated using total case divide by positive case

\begin{tabular}{|c|c|c|c|c|c|c|c|c|}
\hline \multirow[b]{2}{*}{ Genes } & \multirow[b]{2}{*}{$\begin{array}{c}\text { Expression } \\
(\%)\end{array}$} & \multicolumn{2}{|c|}{ Leukemia } & \multirow[b]{2}{*}{ Methylation (\%) } & \multirow[b]{2}{*}{$\begin{array}{c}\text { Expression } \\
(\%)\end{array}$} & \multicolumn{2}{|c|}{ Brain cancer } & \multirow[b]{2}{*}{ Methylation (\%) } \\
\hline & & LOH/HD (\%) & Mutation (\%) & & & $\begin{array}{l}\mathrm{LOH} / \mathrm{HD} \\
(\%)\end{array}$ & $\begin{array}{c}\text { Mutation } \\
(\%)\end{array}$ & \\
\hline TP53 & Dysregulated [18] & $50[91]$ & $17.3[92]$ & 32 [93] & Dysregulated [94] & $\begin{array}{l}24-53 \% \\
{[95-97]}\end{array}$ & 34 [96-98] & $30-53 \%[99]$ \\
\hline RB1 & $\begin{array}{c}\text { Low } \\
{[100,101]}\end{array}$ & $\begin{array}{c}30-55 \% \\
{[102,103]}\end{array}$ & $\begin{array}{c}0 \% \\
{[102,104]}\end{array}$ & - & - & $0-25 \%[105]$ & $0-30 \%[106]$ & $21 \%[107]$ \\
\hline p16(INK4a) & $61 \%$ bss $[100]$ & $4-76 \%[101]$ & $0-7 \%[101]$ & $2-75 \%[101]$ & $26 \%$ Low $[100,108]$ & $\begin{array}{c}31 \% \\
{[101,109]}\end{array}$ & $\begin{array}{c}1-45 \% \\
{[101,109]}\end{array}$ & $\begin{array}{c}3-19 \% \\
{[101,109]}\end{array}$ \\
\hline $\mathrm{p} 14$ (ARF) & Low [110] & $5 \%[111]$ & $34[112]$ & $\begin{array}{c}0-41 \% \\
{[112-114]}\end{array}$ & Low $[115,116]$ & HD 50\% [117] & $12 \%[117]$ & $\begin{array}{c}16-44 \% \\
{[115-117]}\end{array}$ \\
\hline CHK $1 / 2$ & $6 \%$ Loss [118] & $0 \%[118]$ & $\begin{array}{c}0-2 \% \\
{[118,119]}\end{array}$ & $0 \%[118]$ & - & - & - & - \\
\hline KLF6 & $\begin{array}{c}\text { Lower } \\
{[120,121]}\end{array}$ & - & - & - & $80 \%$ Low [122] & $43[123]$ & $\begin{array}{c}0-5 \% \\
{[124,125]}\end{array}$ & - \\
\hline NF1 & $30.8 \%$ Downregulation [126] & Frequent [127] & $\begin{array}{c}0-33 \% \\
{[128,129]}\end{array}$ & - & $\begin{array}{c}\text { Loss } \\
{[130,131]}\end{array}$ & $\begin{array}{c}\text { Rare } \\
{[130,131]}\end{array}$ & $\begin{array}{c}\text { Rare } \\
{[130,131]}\end{array}$ & - \\
\hline APC & Low [132] & - & - & 48 [132] & NS [133] & $58.8[134]$ & - & $0 \%[135]$ \\
\hline TSC1 & - & - & - & - & - & $15[136]$ & $0 \%[136,137]$ & - \\
\hline DCC & $27.6 \%$ loss [138] & $8-68.4 \%[139-141]$ & - & Frequent & $88 \%$ Low [142] & $50[143]$ & $0 \%[143]$ & \\
\hline BRCA1 & Downregulation [144] & - & - & $13[145]$ & - & $0 \%[146]$ & Rare [146] & $0 \%[146]$ \\
\hline MSH2 & Low or undetectable [147] & - & - & $85.7[148]$ & Dysregulated [149] & - & $14[150]$ & \\
\hline MLH1 & Low & - & - & $24[151]$ & NS [149] & - & $4[150]$ & $17[152]$ \\
\hline PTEN & Low [153] & $0-20 \%[154-156]$ & NS [153] & Nil [153] & Loss [157] & $53[157]$ & $\begin{array}{c}20-40 \% \\
{[109,157]}\end{array}$ & $\begin{array}{c}0-26 \% \\
{[135,157]}\end{array}$ \\
\hline LKB1 & - & - & - & - & Loss [158] & 19 [159] & $0 \%[159]$ & - \\
\hline CDH1 & Loss $[160]$ & 2 [160] & - & $48[160]$ & Low $[160]$ & $31[161]$ & $0 \%[160]$ & $57-66 \%[162]$ \\
\hline TGF-R I & Downregulation [163] & - & - & - & NS [164] & - & Rare [165] & \\
\hline TGF-R II & Low $[166]$ & - & $\begin{array}{c}\text { Rare } \\
{[166,167]}\end{array}$ & - & NS [164] & - & $\begin{array}{c}\text { Rare-3\% } \\
{[165,168]}\end{array}$ & - \\
\hline SMAD4 & Low [169] & - & Rare [169] & - & Low [164] & & $0 \%[170]$ & - \\
\hline SMAD2 & - & 26 [171] & $0 \%$ [172] & - & Low [164] & & $0 \%[170]$ & - \\
\hline
\end{tabular}


Table 3. The expression and inactivation mechanisms of tumor suppressor genes in head and neck and Lung cancer. Note: "—"no report found; "HD" homozygosity deletion; "NS" no significant difference; the average percent was calculated using total case divide by positive case

\begin{tabular}{|c|c|c|c|c|c|c|c|c|}
\hline \multirow[b]{2}{*}{ Gene } & \multicolumn{4}{|c|}{ Head and Neck cancer } & \multicolumn{4}{|c|}{ Lung cancer } \\
\hline & Expression (\%) & LOH/HD (\%) & Mutation (\%) & Methylation (\%) & $\begin{array}{c}\text { Expression } \\
(\%)\end{array}$ & LOH/HD (\%) & $\begin{array}{l}\text { Mutation } \\
(\%)\end{array}$ & Methylation (\%) \\
\hline TP53 & Dysregulated [173] & $\begin{array}{c}47-66 \% \\
{[174,175]}\end{array}$ & $47[176]$ & - & $\begin{array}{c}57.3-63.3 \% \\
{[177,178]}\end{array}$ & $90[179]$ & $88[180]$ & Нуро [181] \\
\hline RB1 & NS [182] & $\begin{array}{c}42-68 \% \\
{[182,183]}\end{array}$ & $0 \%[183]$ & $16[184]$ & Altered [185] & $62.5[186]$ & $20[186]$ & - \\
\hline p16(INK4a) & $68 \%$ Loss $[100]$ & $\begin{array}{c}2-55 \% \\
{[101,187]}\end{array}$ & $1-45 \%[101]$ & $\begin{array}{c}3-47 \% \\
{[101,187]}\end{array}$ & $45 \%$ Loss $[178]$ & $29[188]$ & $0-70 \%[101]$ & 51 [189] \\
\hline p14(ARF) & $15 \%$ Loss $[190]$ & $27-33 \%[187,191-193]$ & HD (12\%) [194] & $16-44 \%[187,191-193]$ & 20.9 [195] & $23-79 \%[196,197]$ & $23[196]$ & $\begin{array}{c}0 \% \\
{[196.197]}\end{array}$ \\
\hline CHK $1 / 2$ & - & - & - & - & $83 \%$ Low [198] & - & Low $[198,199]$ & Hyper [198] \\
\hline $\begin{array}{l}\text { KLF6 } \\
\text { NF1 }\end{array}$ & $\overline{-}$ & $30[200]$ & $16[201]$ & $\frac{-}{-}$ & $\begin{array}{c}85 \% \text { Low [202] } \\
-\end{array}$ & $34[202]$ & $\begin{array}{c}0 \%[202] \\
8[203]\end{array}$ & $0 \%[202]$ \\
\hline APC & $30 \%$ Low [204] & $\begin{array}{c}13-35 \% \\
{[205-207]}\end{array}$ & $\begin{array}{c}0-2 \% \\
{[205,206]}\end{array}$ & $10-15 \%[207,208]$ & - & $44-81 \%[209]$ & $3-5 \%[210]$ & $59.0 \%[211]$ \\
\hline TSC1 & Low [212] & $40[212]$ & $0 \%[212]$ & - & - & $0 \%[213]$ & $10.6 \%[213]$ & - \\
\hline DCC & - & 38 [214] & - & $54.2-59 \%[215,216]$ & Low [217] & $\begin{array}{c}50 \% \\
{[217-219]}\end{array}$ & Rare [218] & - \\
\hline BRCA1 & $67 \%$ Weak [220] & - & $5.72 \%$ Rare $[221]$ & - & 51.5 [222] & - & Rare [223] & $18.6[224]$ \\
\hline MSH2 & $88 \%$ Low [225] & $18[225]$ & $\begin{array}{c}0-3 \% \\
{[225,226]}\end{array}$ & $50[227]$ & $36.9[228]$ & $33[229]$ & $0 \%[229]$ & $28.6[230]$ \\
\hline MLH1 & $58 \%$ Low $[225]$ & 55 [225] & $\begin{array}{c}0 \% \\
{[225,226]}\end{array}$ & $28.6[231]$ & 59 [229] & $53[229]$ & $0 \%[229]$ & $55[230]$ \\
\hline PTEN & $31.2[232]$ & $41-71 \%[232]$ & $9-23 \%[232]$ & $0 \%[191]$ & $32.8[233]$ & Rare [234] & $1.6-9 . .8 \%[235]$ & $26[234]$ \\
\hline LKB1 & Low [236] & - & $\begin{array}{c}12.5 \% \\
{[236,237]}\end{array}$ & - & Loss [238] & 65 [239] & $15-30 \%[240]$ & $3[241]$ \\
\hline CDH1 & Decreased [160] & $0-7 \%[160]$ & $4-24 \%[160]$ & $43[160]$ & Reduced [242] & $36[243]$ & $0 \%[242]$ & $\begin{array}{c}30-66 \% \\
{[244,245]}\end{array}$ \\
\hline TGF-R I & $\begin{array}{l}83 \% \text { Loss } \\
{[246,247]}\end{array}$ & - & $\begin{array}{c}\text { Rare } \\
{[248,249]}\end{array}$ & $62[247]$ & $31 \%$ Loss $[250]$ & - & Rare $[251,252]$ & $0 \%[250]$ \\
\hline TGF-R II & Decreased [246] & - & $\begin{array}{c}\text { Rare } \\
{[248,249]}\end{array}$ & - & Decreased [253] & Frequent [251] & $\begin{array}{c}\text { Rare } \\
{[251,252]}\end{array}$ & Frequent [254] \\
\hline SMAD4 & $12 \%$ Failed [255] & $\begin{array}{c}47 \\
{[256,257]}\end{array}$ & $3[256,258]$ & - & $62.5 \%$ Loss $[178]$ & $38[218]$ & $0 \%[259]$ & - \\
\hline SMAD2 & $38 \%$ Loss [260] & & $0 \%[260]$ & - & NS [261] & - & $0 \%[262]$ & - \\
\hline
\end{tabular}

Table 4. The expression and inactivation mechanisms of tumor suppressor genes in cancer. Note: "—"no report found; "HD" homozygosity deletion; "NS" no significant difference; the average percent was calculated using total case divide by positive case

\begin{tabular}{|c|c|c|c|c|c|c|c|c|}
\hline \multirow[b]{2}{*}{ Gene } & \multicolumn{4}{|c|}{ Esophageal cancer } & \multicolumn{4}{|c|}{ Gastric cancer } \\
\hline & Expression (\%) & LOH/HD (\%) & Mutation (\%) & Methylation (\%) & $\begin{array}{c}\text { Expression } \\
(\%)\end{array}$ & LOH/HD (\%) & $\begin{array}{c}\text { Mutation } \\
(\%)\end{array}$ & Methylation (\%) \\
\hline TP53 & 41.9 [263] & $\begin{array}{c}67.5 \\
{[264,265]}\end{array}$ & $50-60[266]$ & - & Overexpression [267] & $0-83 \%[267]$ & $\begin{array}{c}0-77 \% \\
{[267,268]}\end{array}$ & $0 \%[267,268]$ \\
\hline RB1 & 6.5 [269] & 34 [269] & $9[270]$ & $44[271]$ & NS [272] & $29[272]$ & - & - \\
\hline p16(INK4a) & Loss [101] & $17-22[101,273]$ & $0-52 \%[101]$ & $\begin{array}{c}19-62 \% \\
{[101,273]}\end{array}$ & Loss [101] & $0-9 \%[101]$ & $0-2 \%[101]$ & $\begin{array}{c}17-42 \% \\
{[101,274,275]}\end{array}$ \\
\hline p14(ARF) & $\begin{array}{c}\text { Loss } \\
{[273,276]}\end{array}$ & $\begin{array}{c}33 \\
{[273,276]}\end{array}$ & $\begin{array}{c}0 \% \\
{[273,276]}\end{array}$ & $\begin{array}{c}0-19 \% \\
{[273,276]}\end{array}$ & Loss [277] & $\begin{array}{c}71.4 \\
{[275,277]}\end{array}$ & $0 \%[274]$ & $\begin{array}{c}24-33 \% \\
{[274,277]}\end{array}$ \\
\hline CHK $1 / 2$ & Loss & - & - & - & Overexpression [278] & - & $2 \%[250,279]$ & - \\
\hline KLF6 & - & - & Frequent [280] & - & 48\% Reduce [281] & $43 \%[282]$ & $5 \%[282]$ & - \\
\hline NF1 & - & $80 \%$ [283] & - & - & NS [284] & - & - & - \\
\hline APC & $11 \%$ Low [285] & $\begin{array}{c}29 \% \\
{[285,286]}\end{array}$ & $10 \%[287]$ & $\begin{array}{c}68-78 \% \\
{[215,288]}\end{array}$ & $78 \%$ Loss [289] & $\begin{array}{c}37 \% \\
{[290,291]}\end{array}$ & $20 \%[292,293]$ & $84 \%[293]$ \\
\hline TSC1 & - & - & - & - & - & - & - & - \\
\hline DCC & Low [294] & $23 \%$ [295] & $4 \%$ [295] & $74 \%$ [294] & Loss [296] & $\begin{array}{c}35 \% \\
{[297,298]}\end{array}$ & $0 \%[296]$ & $\begin{array}{c}45 \% \\
{[296,298]}\end{array}$ \\
\hline BRCA1 & $88.6 \%$ [299] & - & - & - & & $40 \%[300]$ & - & - \\
\hline MSH2 & 20\% Low [301] & - & - & $48.3 \%[302]$ & Low $[303,304]$ & - & $17 \%$ [305-307] & $17 \%[307]$ \\
\hline MLH1 & $27 \%[308]$ & - & - & $60 \%$ [309] & Low [304] & - & $21 \%[307]$ & $\begin{array}{c}4.6 \% \\
{[306,307]}\end{array}$ \\
\hline $\begin{array}{l}\text { PTEN } \\
\text { LKB1 }\end{array}$ & NS $[310]$ & $\begin{array}{c}9 \%[311] \\
-\end{array}$ & $\begin{array}{c}3 \%[312] \\
-\end{array}$ & $\begin{array}{c}18.9 \%[313] \\
-\end{array}$ & $\begin{array}{l}\text { Low [314] } \\
\text { Low [318] }\end{array}$ & $\stackrel{4.4 \%[315]}{-}$ & $\begin{array}{c}18.7 \%[316] \\
11 \%[318]\end{array}$ & $\begin{array}{c}39 \%[317] \\
-\end{array}$ \\
\hline CDH1 & $59.6 \%[319]$ & $68 \%[160]$ & $2 \%[311]$ & $97.9 \%[319]$ & Low $[160]$ & $10-24 \%[160]$ & $0-41 \%[160]$ & $49-75 \%[160]$ \\
\hline TGF-R I & $54 \%$ Low $[320]$ & - & Rare [321] & - & $82 \%$ Low [322] & - & - & $12.5-50 \%[323,324$ \\
\hline TGF-R II & $29 \%$ Low $[320]$ & - & Rare [321] & - & $42 \%$ Loss [325] & $\begin{array}{c}33 \% \\
{[324,326]}\end{array}$ & $\begin{array}{c}10 \% \\
{[324,326]}\end{array}$ & \\
\hline SMAD4 & 68\% Loss [327] & $46 \%[328]$ & $5.9 \%[287]$ & $70 \%[329]$ & $40 \%$ Loss [75] & $\begin{array}{l}29-41 \% \\
{[75,330]}\end{array}$ & rare & $5 \%[75]$ \\
\hline SMAD2 & Low [331] & $35 \%[331]$ & $0 \%[254]$ & - & $\begin{array}{c}\text { Low } \\
{[75,330]}\end{array}$ & Frequent [332] & $0 \%$ [333] & - \\
\hline
\end{tabular}

MDM4 has been found in approximately $10 \%$ of all tumors and in $65 \%$ of retinoblastomas $[21,28]$. Viruses may also promote the degradation of p53. The human papilloma virus E6 protein forms a complex with the homologous to the E6 carboxyl terminus (HECT) domain of E3 ubiquitin ligase, which results in the ubiquitination and degradation of p53 [21, 29, 30]. These findings are consistent with the idea that the ubiquitin-proteasome pathway promotes tumorigenesis through the loss of p53 function. 
Table 5. The expression and inactivation mechanisms of tumor suppressor genes in cancer. Note: “-"no report found; "HD" homozygosity deletion; "NS" no significant difference; the average percent was calculated using total case divide by positive case

\begin{tabular}{|c|c|c|c|c|c|c|c|c|}
\hline \multirow[b]{2}{*}{ Gene } & \multirow[b]{2}{*}{$\begin{array}{c}\text { Expression } \\
(\%)\end{array}$} & \multicolumn{2}{|c|}{ Cobrectal cancer } & \multirow[b]{2}{*}{$\begin{array}{l}\text { Methylation } \\
(\%)\end{array}$} & \multirow[b]{2}{*}{$\begin{array}{c}\text { Expression } \\
(\%)\end{array}$} & \multicolumn{2}{|c|}{ Pancreatic Cancer } & \multirow[b]{2}{*}{$\begin{array}{c}\text { Methylation } \\
(\%)\end{array}$} \\
\hline & & LOH/HD (\%) & Mutation (\%) & & & $\begin{array}{c}\mathrm{LOH} / \mathrm{HD} \\
(\%)\end{array}$ & Mutation (\%) & \\
\hline TP53 & Overexpression [334] & $\begin{array}{c}66 \% \\
{[335-338]}\end{array}$ & $45 \%[334]$ & - & Overexpression [339] & - & $\begin{array}{c}43 \% \\
{[340-342]}\end{array}$ & - \\
\hline RB1 & NS [343] & $50 \%[344]$ & - & - & NS [345] & $6 \%[346]$ & - & - \\
\hline p16(INK4a) & $27 \%$ Loss [101] & $81 \%[347]$ & - & $10-53 \%[101]$ & $\begin{array}{l}85 \% \text { Loss } \\
{[100,101]}\end{array}$ & $\begin{array}{l}30 \% \\
{[101]}\end{array}$ & $\begin{array}{c}17-38 \% \\
{[101]}\end{array}$ & $13 \%[101]$ \\
\hline $\mathrm{p} 14$ (ARF) & Loss [348] & - & - & $\begin{array}{c}4-28 \% \\
{[349-351]}\end{array}$ & $53 \%$ Loss [352] & - & Rare [353] & $\begin{array}{c}0-14 \% \\
{[354,355]}\end{array}$ \\
\hline CHK $1 / 2$ & $50 \%$ decreased [356] & Frequent [357] & - & Rare [358] & Overexpression [359] & - & - & - \\
\hline KLF6 & $\begin{array}{l}37 \% \text { Loss } \\
{[360,361]}\end{array}$ & $\begin{array}{c}29-52 \% \\
{[361,362]}\end{array}$ & $17-45 \%[361-363]$ & - & - & $0 \%[364]$ & $0 \%[364]$ & - \\
\hline NF1 & Overexpression [365] & $14-57 \%[344,365,366]$ & $\begin{array}{c}3-8 \% \\
{[366,367]}\end{array}$ & - & - & - & - & - \\
\hline APC & Low $[368,369]$ & $\begin{array}{c}30-47.8 \%[338,370 \\
371]\end{array}$ & $\begin{array}{c}26.7-83 \%[371, \\
372]\end{array}$ & $\begin{array}{c}10-50 \%[369 \\
373]\end{array}$ & Loss [374] & $\begin{array}{c}\text { Rare } \\
{[375,376]}\end{array}$ & $\begin{array}{c}40 \% \\
{[375,376]}\end{array}$ & $10-45 \%[354]$ \\
\hline TSC1 & - & - & - & - & - & - & - & - \\
\hline DCC & $\begin{array}{c}40 \% \text { decreased }[377, \\
378]\end{array}$ & $64.3 \%[338,344,378]$ & $17 \%[378]$ & $82.7 \%[379]$ & $\begin{array}{l}59 \% \text { Loss } \\
{[346,380]}\end{array}$ & $\begin{array}{l}50 \% \\
{[381]}\end{array}$ & - & - \\
\hline BRCA1 & Decreased [382] & $\begin{array}{c}39.8 \% \\
{[383,384]}\end{array}$ & - & - & $\begin{array}{c}\text { Down-regulation } \\
{[300]}\end{array}$ & - & Rare [385] & - \\
\hline MSH2 & $\begin{array}{l}33.3 \% \text { reduced [ } 386, \\
\quad 387]\end{array}$ & Frequent [388] & Rare $[389,390]$ & $10 \%[387]$ & $14 \%$ Loss [391] & - & $0 \%[392]$ & - \\
\hline MLH1 & $50 \%$ reduced $[386,387]$ & Frequent [388] & Rare $[389,390]$ & $\begin{array}{c}18-39 \% \\
{[350,351]}\end{array}$ & NS [391] & - & $0 \%[392]$ & $4 \%[393,394]$ \\
\hline PTEN & $34.3 \%$ Loss [395] & $9 \%[157]$ & $\begin{array}{c}2-8 \% \\
{[157,395]}\end{array}$ & $\begin{array}{c}27.3 \% \\
{[394,395]}\end{array}$ & $\begin{array}{l}\text { Decreased } \\
{[396,397]}\end{array}$ & $\begin{array}{l}35 \% \\
{[398]}\end{array}$ & $0 \%[398]$ & Frequent [396] \\
\hline LKB1 & - & $13-52.6 \%[399,400]$ & $0-53.8 \%[399,400]$ & $8 \%[400]$ & $7 \%$ Loss [401] & $\begin{array}{l}32 \% \\
{[402]}\end{array}$ & $4-6 \%[402]$ & - \\
\hline CDH1 & Reduce [160] & $13 \%[160]$ & $0 \%[160]$ & $\begin{array}{c}20,46 \% \\
{[160,403]}\end{array}$ & $45 \%$ reduce $[404]$ & - & - & $29 \%[405]$ \\
\hline TGF-R I & Down-regulation [406] & - & - & - & NS [407] & - & Rare [408] & - \\
\hline TGF-R II & Down-regulation [406] & - & $\begin{array}{c}10-30 \% \\
{[409,410]}\end{array}$ & $0 \%[409]$ & Overexpression [407] & - & Rare [408] & - \\
\hline SMAD4 & $38 \% \operatorname{Loss}[381]$ & $35 \%[411]$ & $\begin{array}{c}6-16 \% \\
{[411,412]}\end{array}$ & $0 \%[413]$ & $55 \%$ Loss [414] & $\begin{array}{l}30-37 \% \\
{[69,415]}\end{array}$ & $\begin{array}{c}16-44 \% \\
{[415]}\end{array}$ & - \\
\hline SMAD2 & Loss [416] & $10 \%[417]$ & $0 \%[417]$ & - & Overexpression [418] & - & - & - \\
\hline
\end{tabular}

Table 6. The expression and inactivation mechanisms of tumor suppressor genes in cancer. Note: "-"no report found; "HD" homozygosity deletion; "NS" no significant difference; the average percent was calculated using total case divide by positive case

\begin{tabular}{|c|c|c|c|c|c|c|c|c|}
\hline \multirow[b]{2}{*}{ Gene } & \multicolumn{3}{|c|}{ Hepatocellular cancer } & \multirow[b]{2}{*}{ Methylation (\%) } & \multicolumn{4}{|c|}{ Bladder cancer } \\
\hline & $\begin{array}{c}\text { Expression } \\
(\%)\end{array}$ & LOH/HD (\%) & Mutation (\%) & & Expression (\%) & $\begin{array}{l}\mathrm{LOH} / \mathrm{HD} \\
(\%)\end{array}$ & $\begin{array}{c}\text { Mutation } \\
(\%)\end{array}$ & Methylation (\%) \\
\hline TP53 & $\begin{array}{c}\text { Overexpression } \\
\text { [419] }\end{array}$ & $\begin{array}{c}16 \% \\
{[420-422]}\end{array}$ & $\begin{array}{c}51 \% \\
{[420-422]}\end{array}$ & $\begin{array}{c}20 \% \\
{[423,424]}\end{array}$ & $\begin{array}{c}\text { Overexpression } \\
{[425]}\end{array}$ & $73 \%[426]$ & $\begin{array}{c}23-61 \% \\
{[425,427,428]}\end{array}$ & - \\
\hline RB1 & $\begin{array}{l}\text { Loss } \\
{[424,429]}\end{array}$ & $\begin{array}{c}33-50 \% \\
{[429,430]}\end{array}$ & $15 \%[429]$ & $\begin{array}{c}0-26 \%[424, \\
431]\end{array}$ & - & $\begin{array}{l}12.5-29 \% \\
{[432,433]}\end{array}$ & $27 \%[434]$ & $28 \%[435]$ \\
\hline p16(INK4a) & $46 \%$ Loss $[436]$ & $\begin{array}{c}7 \% \\
{[436-438]}\end{array}$ & $0 \%[436-438]$ & $\begin{array}{c}24-84 \% \\
{[436-438]}\end{array}$ & $\begin{array}{c}\text { Loss } \\
{[100,439,440]}\end{array}$ & $\begin{array}{c}32 \%[100,101,439 \\
440]\end{array}$ & $\begin{array}{c}0-7 \%[100,101,439 \\
440]\end{array}$ & $\begin{array}{c}23 \% \\
{[100,101,439} \\
440]\end{array}$ \\
\hline p14(ARF) & NS [441] & $\begin{array}{c}69 \%[438,441, \\
442]\end{array}$ & $\begin{array}{c}4 \% \\
{[441,442]}\end{array}$ & $\begin{array}{c}0-39 \% \\
{[441,442]}\end{array}$ & - & $22 \%[443]$ & - & $\begin{array}{c}42 \% \\
{[444,445]}\end{array}$ \\
\hline CHK $1 / 2$ & High [446] & - & - & - & $10 \%$ Reduce [447] & $6 \%[448]$ & $3 \%[447,448]$ & - \\
\hline KLF6 6 & Loss [449] & $39 \%[450]$ & $0-5 \%[450,451]$ & $1 \%[452]$ & - & - & - & - \\
\hline NF1 & Rare & - & & - & Decreased [453] & $31 \%[454,455]$ & Rare [456] & - \\
\hline \multirow[t]{2}{*}{ APC } & Reduce [457] & $\begin{array}{c}14 \% \\
{[458,459]}\end{array}$ & $\begin{array}{c}3 \%[424,458, \\
\quad 460]\end{array}$ & $\begin{array}{c}53-82 \%[457 \\
461]\end{array}$ & NS [462] & $\begin{array}{c}6-10 \% \\
{[462,463]}\end{array}$ & $0 \%[462]$ & $35 \%[464]$ \\
\hline & - & - & $16.2 \%[465]$ & - & - & $32.4 \%[466]$ & $\begin{array}{c}7-11 \% \\
{[466-468]}\end{array}$ & - \\
\hline DCC & - & $14 \%[459]$ & - & Rare [469] & - & $36 \%[463]$ & - & NS [470] \\
\hline BRCA1 & - & $12 \%[459]$ & - & $0 \%[438]$ & - & - & - & - \\
\hline MSH2 & $18 \%$ Reduce $[471]$ & $\begin{array}{l}20 \% \\
{[472]}\end{array}$ & $\begin{array}{c}34 \% \\
{[473,474]}\end{array}$ & $68 \%[475]$ & $\begin{array}{c}\text { Loss } \\
{[476,477]}\end{array}$ & $4 \%[477]$ & $\begin{array}{c}0-73 \% \\
{[478,479]}\end{array}$ & - \\
\hline MLH1 & $38 \%$ Reduce $[471]$ & $20 \%[472]$ & - & $13.2 \%[475]$ & $\begin{array}{l}\text { Loss } \\
{[476,477]}\end{array}$ & $2 \%[477]$ & $0 \%[480]$ & Rare [481] \\
\hline PTEN & $35 \%$ Loss [482] & - & $3 \%[398]$ & $0 \%[438]$ & $\begin{array}{l}53 \% \text { decreased } \\
\text { [483] }\end{array}$ & $24 \%[398]$ & $2 \%[398]$ & - \\
\hline LKB1 & $\begin{array}{c}\text { Overexpressed } \\
\text { [484] }\end{array}$ & $22 \%[485]$ & $1 \%[485]$ & $4.2 \%[486]$ & NS [487] & - & - & - \\
\hline CDH1 & Reduce [160] & $46 \%[160]$ & $0 \%[160]$ & $41 \%[160]$ & Reduce [160] & $14 \%[160]$ & $3 \%[160]$ & $43 \%[160]$ \\
\hline TGF-R I & Reduce [488] & - & - & - & NS [489] & - & $5 \%[490]$ & - \\
\hline TGF-R II & Reduce [488] & - & $0 \%$ [491] & - & Reduce [489] & - & - & - \\
\hline SMAD4 & $\begin{array}{c}\text { Overexpression } \\
{[492]}\end{array}$ & - & $\begin{array}{c}3 \% \\
{[493,494]}\end{array}$ & - & $68 \%$ Reduce [495] & $84 \%$ [495] & - & - \\
\hline SMAD2 & Reduce [482] & - & $\begin{array}{c}\text { Rare } \\
\text { Ra3, 494] }\end{array}$ & - & $34 \%$ Reduce [495] & - & - & - \\
\hline
\end{tabular}

\section{Inactivation of INK4A/ARF via ubiquitin-proteasomal degradation}

p16 ${ }^{\mathrm{INK} 4 \mathrm{~A}}$ and $\mathrm{p} 14^{\mathrm{ARF}}$ are well-studied pro-apoptotic proteins due to their critical role in cell cycle arrest and cellular senescence, and their consequent association with malignancy [3133]. Numerous studies have investigated the mechanism of inactivation of the INK4A/ARF locus in human cancers (Table 2 -9). Like p53, p14 ${ }^{\mathrm{ARF}}$ is a direct target of polyubiquitination and proteasomal degradation. p14 ${ }^{\mathrm{ARF}}$ specifically binds to MDM2, which has E3 ligase activity and induces the proteasomal degradation of MDM2. Thus, p14 ${ }^{\mathrm{ARF}}$ stabilizes transcriptionally 
Wang et al.: Loss of Tumor Suppressor Genes Function

Table 7. The expression and inactivation mechanisms of tumor suppressor genes in cancer. Note: "-"no report found; "HD" homozygosity deletion; "NS" no significant difference; the average percent was calculated using total case divide by positive case

\begin{tabular}{|c|c|c|c|c|c|c|}
\hline \multirow[b]{2}{*}{ Expression (\%) } & \multicolumn{2}{|c|}{ Renal cancer } & \multirow[b]{2}{*}{ Methylation (\%) } & \multirow[b]{2}{*}{$\begin{array}{c}\text { Expression } \\
(\%)\end{array}$} & \multicolumn{2}{|c|}{ Prostate cancer } \\
\hline & LOH/HD (\%) & Mutation (\%) & & & LOH/HD (\%) & $\begin{array}{l}\text { Mutation } \\
(\%)\end{array}$ \\
\hline $\begin{array}{c}\text { Overexpression } \\
{[496]}\end{array}$ & $\begin{array}{c}20-48 \%[426,497- \\
499]\end{array}$ & $\begin{array}{c}0-33 \%[498- \\
500]\end{array}$ & NS [501] & $\begin{array}{c}\text { Overexpression [496, } \\
502]\end{array}$ & $\begin{array}{c}32-39 \%[502- \\
504]\end{array}$ & $\begin{array}{c}\text { 6-13\% [502, 503, } \\
505]\end{array}$ \\
\hline Weak [506] & $\begin{array}{c}60 \% \\
{[497,507]}\end{array}$ & Rare [508] & NS [445] & Loss $[509,510]$ & $\begin{array}{c}5-60 \% \\
{[509-511]}\end{array}$ & $16 \%[512]$ \\
\hline $\begin{array}{l}52.9 \% \text { Weak }[506, \\
514]\end{array}$ & $2-16 \%[101]$ & NS [515] & $\begin{array}{c}10-35 \%[101,514,516, \\
517]\end{array}$ & Loss [100] & $4 \%[101]$ & $0-6 \%[101]$ \\
\hline Reduce [519] & $\begin{array}{l}23.5-83 \%[519, \\
520]\end{array}$ & - & $\begin{array}{c}0-17 \% \\
{[516,520]}\end{array}$ & Loss [521] & $4 \%[521]$ & - \\
\hline- & - & - & {$\left[\begin{array}{c}0+00] \\
-\end{array}\right.$} & - & NS [523] & $1.2 \%[524]$ \\
\hline- & - & $5 \%[525]$ & - & Loss $[526,527]$ & $\begin{array}{c}19 \% \\
{[526,528]}\end{array}$ & $55 \%[526]$ \\
\hline- & - & Rare [456] & - & - & $\begin{array}{c}{[3<0,5<0]} \\
-\end{array}$ & - \\
\hline Loss [529] & $\begin{array}{c}14-43 \%[507,529 \\
530]\end{array}$ & $3 \%$ [529] & $\begin{array}{c}14-29 \% \\
{[516,517]}\end{array}$ & - & $20 \%[531]$ & $\begin{array}{c}3-10 \% \\
{[511,532]}\end{array}$ \\
\hline- & $\begin{array}{c}7-18 \% \\
{[525,534]}\end{array}$ & $0 \%[534]$ & - & - & - & - \\
\hline Reduce [535] & $\begin{array}{c}7 \% \\
{[497,536]}\end{array}$ & - & - & Reduce [537] & $\begin{array}{c}26-29 \%[531 \\
537]\end{array}$ & Rare [538] \\
\hline Moderate [539] & $0 \%$ [539] & - & - & Reduce [540] & $17 \%[541]$ & Rare $[541,542]$ \\
\hline Loss $[544,545]$ & - & - & Frequent [545] & Reduce [546] & - & $83 \%[547,548]$ \\
\hline Loss $[544,545]$ & $35 \%[481]$ & - & $0 \%[481,549]$ & Reduce [546] & - & - \\
\hline $\begin{array}{c}\text { Overexpression } \\
{[550]}\end{array}$ & $27 \%[398]$ & $\begin{array}{c}5-7 \% \\
{[398,525]}\end{array}$ & - & Reduce & $33 \%$ [398] & $15 \%[398]$ \\
\hline- & - & {$[0$} & - & - & - & - \\
\hline 67\%Lacked [551] & $7.5 \%[530]$ & - & $\begin{array}{c}11-67 \% \\
{[516,517]}\end{array}$ & Reduce [160] & $38 \%[160]$ & $0 \%[160]$ \\
\hline- & - & $5 \%[490]$ & - & Reduce [552] & - & - \\
\hline Reduce [553] & - & - & - & Reduce [552] & - & $12 \%[554]$ \\
\hline Reduce [556] & $13 \%[557]$ & $0 \%[490]$ & - & Loss [558] & $10 \%[559]$ & Rare [559] \\
\hline NS [561] & - & - & - & NS [562] & - & $0 \%[562]$ \\
\hline
\end{tabular}

Table 8. The expression and inactivation mechanisms of tumor suppressor genes in Breast and Ovarian cancer. Note: "-"no report found; "HD" homozygosity deletion; "NS" no significant difference; the average percent was calculated using total case divide by positive case

\begin{tabular}{|c|c|c|c|c|c|c|c|c|}
\hline \multirow[b]{2}{*}{ Gene } & \multirow[b]{2}{*}{ Expression (\%) } & \multicolumn{2}{|c|}{ Breast cancer } & \multirow[b]{2}{*}{ Methylation (\%) } & \multicolumn{4}{|c|}{ Ovarian cancer } \\
\hline & & LOH/HD (\%) & Mutation (\%) & & Expression (\%) & LOH/HD (\%) & $\begin{array}{l}\text { Mutation } \\
(\%)\end{array}$ & Methylation (\%) \\
\hline TP53 & Overexpression [563] & $\begin{array}{c}49 \% \\
{[564-566]}\end{array}$ & $8-39 \%[505]$ & $11.5 \%[567]$ & $\begin{array}{l}\text { Low/High } \\
{[568,569]}\end{array}$ & $\begin{array}{c}44-63 \%[570- \\
572]\end{array}$ & $\begin{array}{l}20.7-23 \% \\
{[572,573]}\end{array}$ & $51.5 \%[574]$ \\
\hline RB1 & $\begin{array}{l}\text { Loss / reduced [575, } \\
576]\end{array}$ & $\begin{array}{c}26-47 \%[577, \\
578]\end{array}$ & Nil [576] & Nil [576] & $83 \%$ Loss [579] & $61 \%[580]$ & $67 \%[581]$ & - \\
\hline p16(INK4a) & $48.9 \%$ Low $[100,582]$ & $\begin{array}{c}0-10 \% \\
{[101,583]}\end{array}$ & $3-5 \%[101]$ & $\begin{array}{c}17-38.3 \%[101 \\
582]\end{array}$ & $\begin{array}{l}\text { Reduced } \\
{[100,584]}\end{array}$ & $0-14 \%[101]$ & $0-11 \%[101]$ & $\begin{array}{c}0-43 \%[101,584 \\
585]\end{array}$ \\
\hline p14(ARF) & $\begin{array}{c}\text { Overexpression /Loss } \\
\text { [586] }\end{array}$ & $\begin{array}{c}21 \% \\
{[583,586]}\end{array}$ & $0 \%[583]$ & $24 \%[583]$ & Absent [587] & - & - & $\begin{array}{c}0-18 \% \\
{[588,589]}\end{array}$ \\
\hline CHK2 & $\begin{array}{c}\text { Reduce } \\
{[590,591]}\end{array}$ & $44 \%[358]$ & $\begin{array}{c}\text { Rare [590,592, } \\
593]\end{array}$ & Nil [592] & 23\% Negative [358] & $54 \%[358]$ & $\begin{array}{c}2.3 \% \\
{[593,594]}\end{array}$ & Rare [358] \\
\hline KLF6 & $\begin{array}{l}\text { Reduce } \\
{[595,596]}\end{array}$ & - & Rare [595] & - & Reduce [597] & $59 \%[597]$ & - & - \\
\hline NF1 & - & Frequent [598] & $\begin{array}{l}0-27.7 \%[598, \\
599]\end{array}$ & - & Reduce [600] & $56 \%[601]$ & $\begin{array}{c}0-14.5 \% \\
{[602,603]}\end{array}$ & - \\
\hline APC & $\begin{array}{c}41 \% \text { Reduce } \\
{[604,605]}\end{array}$ & $\begin{array}{c}23-38 \%[606- \\
608]\end{array}$ & $0-6 \%[607,608]$ & $30.6 \%[609]$ & Absent [610] & $50 \%$ [611-613] & $\begin{array}{c}0.89 \% \\
{[613,614]}\end{array}$ & $\begin{array}{c}16-22 \% \\
{[585,615]}\end{array}$ \\
\hline TSC1 & Reduce [616] & - & - & Frequent [616] & - & - & - & - \\
\hline DCC & $56 \%$ Reduce $[604,617]$ & $\begin{array}{c}31 \% \\
{[605,618]}\end{array}$ & - & - & $\begin{array}{l}59 \% \text { Loss } \\
{[619,620]}\end{array}$ & $38 \%[621]$ & - & - \\
\hline BRCA1 & Loss [622] & $21-42 \%[623]$ & $3.9 \%[624]$ & $\begin{array}{c}11-31 \% \\
{[609,625]}\end{array}$ & $\begin{array}{l}72 \% \text { Decreased } \\
\text { [626] }\end{array}$ & $66 \%[626]$ & $15 \%[627]$ & $31 \%[626]$ \\
\hline MSH2 & $28 \%$ Reduce [628] & $\begin{array}{c}\text { Frequent [629, } \\
630]\end{array}$ & $9 \%[631]$ & $16 \%[629]$ & $38 \%$ Loss [632] & $12.5 \%[633]$ & $0.18 \%[634]$ & - \\
\hline MLH1 & Reduce [635] & Frequent [630] & $25 \%[631]$ & $31-44 \%[631]$ & $56 \%$ Loss [636] & $47 \%[637]$ & $8.2 \%[573]$ & $12.5 \%[638]$ \\
\hline PTEN & $55.1 \%$ Reduce $[639,640]$ & $\begin{array}{l}31-63.3 \% \\
{[398,640]}\end{array}$ & $\begin{array}{c}2-5 \% \\
{[398,641]}\end{array}$ & $48 \%[641]$ & $37.5 \%$ Reduce [642] & $39 \%[398]$ & $8 \%[398]$ & $12.5 \%[643]$ \\
\hline LKB1 & $\begin{array}{c}\text { Low / Overexpression } \\
{[644,645]}\end{array}$ & $31.5 \%[646]$ & Nil [647] & Rare [648] & $54 \%$ Loss [649] & $24 \%[650]$ & $4 \%[650]$ & - \\
\hline CDH1 & Loss [651] & $73 \%[606]$ & $22 \%[606]$ & $41 \%[606]$ & Reduce [652] & - & Rare [160] & $\begin{array}{c}13-26 \% \\
{[160,585]}\end{array}$ \\
\hline TGF-R I & Overexpression [653] & - & - & - & NS [654] & - & $31 \%[655]$ & - \\
\hline TGF-R II & Overexpression [653] & - & $0-24 \%[656]$ & - & Reduce [654] & - & $\begin{array}{c}25 \%[655, \\
657]\end{array}$ & - \\
\hline SMAD4 & Loss [658] & Frequent [659] & - & - & NS [660] & $42 \%[661]$ & $3.8 \%[662]$ & - \\
\hline SMAD2 & Reduce [663] & Frequent [663] & - & - & $28 \%$ bss [674] & $46 \%[661]$ & $37.5 \%$ [655] & - \\
\hline
\end{tabular}

active p53 by inducing the degradation of MDM2 [34, 35]. Similarly, MDM2 overexpression in several cancer cell line causes p14ARF degradation via proteasome [36]. Thus, p14ARFmediated disruption of p53 pathway mechanisms have been found in number of carcinomas [37]. 
Table 9. The expression and inactivation mechanisms of tumor suppressor genes in cervical and endometrial cancer. Note: "-"no report found; "HD" homozygosity deletion; "NS" no significant difference; the average percent was calculated using total case divide by positive case

\begin{tabular}{|c|c|c|c|c|c|c|}
\hline \multirow[b]{2}{*}{ Expression (\%) } & \multicolumn{2}{|c|}{ Cervical cancer } & \multirow[b]{2}{*}{ Methylation (\%) } & \multirow[b]{2}{*}{ Expression (\%) } & \multicolumn{2}{|c|}{ Endometrial cancer } \\
\hline & LOH/HD (\%) & $\begin{array}{c}\text { Mutation } \\
(\%)\end{array}$ & & & LOH/HD (\%) & Mutation (\%) \\
\hline $\begin{array}{l}\text { Over/Low } \\
{[664,665]}\end{array}$ & $\begin{array}{c}20 \% \\
{[666,667]}\end{array}$ & $\begin{array}{c}\text { Rare } \\
{[667,668]}\end{array}$ & $12 \%[669]$ & $\begin{array}{l}\text { Over /Low [670- } \\
\quad 672]\end{array}$ & $\begin{array}{c}19-32 \%[673- \\
675]\end{array}$ & $\begin{array}{c}14-22 \%[672,675- \\
677]\end{array}$ \\
\hline Low $[679,680]$ & $\begin{array}{c}62.8 \% \\
{[679,681]}\end{array}$ & - & $4.8 \%[669]$ & NS [682] & $33 \%[683]$ & - \\
\hline $\begin{array}{l}\text { Overexpression [665, } \\
684]\end{array}$ & $\begin{array}{c}17 \% \\
{[681,685]}\end{array}$ & $15 \%[685]$ & $\begin{array}{c}6.5-36 \%[685, \\
686]\end{array}$ & $18 \%$ Loss [100] & $8-13 \%[687,688]$ & $13 \%[687,688]$ \\
\hline Overexpression [684] & - & - & $8.8 \%[686]$ & Low [690] & - & - \\
\hline 2.4\% Expression [691] & - & - & - & Reduce [692] & - & Nil [692] \\
\hline Altered [693] & - & - & - & - & - & - \\
\hline- & - & - & - & - & - & $9 \%[694]$ \\
\hline Increased [695] & $30 \%[696]$ & - & $32 \%$ [697] & Reduced $[698,699]$ & $\begin{array}{l}24.3-60 \% \\
{[699,700]}\end{array}$ & Nil [700] \\
\hline- & - & - & - & Loss [701] & - & $2 \%[694]$ \\
\hline Reduce [702] & $40 \%[703]$ & - & $0-39.8 \%[704]$ & Loss [705] & $14-30 \%[705]$ & - \\
\hline Jownregulation [706] & $5-9 \%[707]$ & - & $6 \%[706]$ & Loss [708] & $24 \%[674]$ & $3 \%[709,710]$ \\
\hline $32 \%$ Loss [711] & - & $9.7 \%[712]$ & - & $\begin{array}{c}\text { Loss } \\
{[713,714]}\end{array}$ & Low [715] & Low [716] \\
\hline Dverexpression [718] & - & $5.5 \%$ [712] & $5.7 \%[719]$ & Loss $[713,714]$ & Frequent [720] & $\begin{array}{c}10-20 \% \\
{[720]}\end{array}$ \\
\hline $\begin{array}{c}\text { Downregulation [ } 722, \\
723]\end{array}$ & $36 \%$ [398] & $4 \%[398]$ & $62 \%[723]$ & $\begin{array}{c}43 \% \text { Loss }[670, \\
701]\end{array}$ & $50 \%[398]$ & $\begin{array}{c}45 \% \\
{[398,694]}\end{array}$ \\
\hline Loss $[724]$ & - & $20 \%[725]$ & - & Loss [701] & - & Nil [726] \\
\hline Reduce [160] & $15 \%[160]$ & $4 \%[160]$ & $\begin{array}{c}28 \% \\
{[160,727]}\end{array}$ & Reduce [728] & - & Rare [729] \\
\hline Overexpression [731] & - & $43 \%[732]$ & - & Reduce [733] & - & $2.6 \%[734]$ \\
\hline NS [731] & $60 \%[735]$ & $6 \%[732]$ & - & Reduce [733] & - & $17 \%[734]$ \\
\hline $\begin{array}{l}24 \% \text { Loss } \\
{[737,738]}\end{array}$ & $\begin{array}{c}10-37 \%[330, \\
737]\end{array}$ & Rare [737] & $0 \%$ [673] & Reduce [739] & $21.4 \%$ [739] & $22 \% H D$ [739] \\
\hline Reduce [738] & $\begin{array}{c}10-37 \%[330, \\
740]\end{array}$ & Nil [330] & - & $\begin{array}{c}\text { Reduce } \\
{[741,742]}\end{array}$ & $15 \%[743]$ & - \\
\hline
\end{tabular}

Inactivation of TGF- $\beta$ family genes via ubiquitin-proteasomal degradation

Members of the TGF- $\beta$ family are multifunctional proteins that are critically involved in many cellular process, including cell growth, survival, differentiation, migration, and apoptosis [38]. Alterations in their downstream signaling pathways are associated with a wide range of diseases, including cancer [38]. Among the TGF- $\beta$ pathway members, TGF- $\beta$ receptor I, TGF- $\beta$ receptor II, SMAD4, and SMAD2 are considered to be classic TSGs. In certain cancers, TGF- $\beta$ signaling is disrupted due to the somatic mutations in components of the TGF- $\beta$ signaling pathway (Table $2-9$ ). E3 ubiquitin ligases play an important role in the recognition and degradation of TGF- $\beta$ family target proteins by the $26 \mathrm{~S}$ proteasome. Ubiquitination of SMADs regulates the TGF- $\beta$ signaling; SMAD ubiquitin regulatory factor (Smurf1, Smurf2), a HECT-type E3 ubiquitin ligases and ROC1-SCF ${ }^{\text {Fbw1a }}$, a RING finger-type E3 ubiquitin ligase, have all been participate in the proteasomal degradation of TGF- $\beta$ signaling members $[39,40]$. Smurf1 and Smurf2 bind to TGF- $\beta$ family receptors through the inhibitory SMADs, SMAD6 and SMAD7, to induce their ubiquitin-dependent protein degradation. Thus, dysregulation in E3 ubiquitin ligases that regulate tumor suppressors of the TGF- $\beta$ family may lead to carcinogenesis and malignant progression of various cancers. Therefore, knowing the status of TGF- $\beta$ and/or its downstream signaling mediators creates an opportunity for the use of selective inhibitors.

\section{Mislocalization of tumor suppressor proteins}

Tumor suppressor proteins are regulated by multiple events to avoid abnormal cellular proliferation, promote apoptosis, or both. Translocation of tumor suppressor proteins provides an efficient means of transducing signals between specific cellular compartments. Certain tumor suppressor proteins show different patterns of localization in normal and 
cancer cells, and impaired spatiotemporal dynamics of tumor suppressor protein signaling has been shown to be involved in carcinogenesis and malignant progression [41, 42]. Next, we discuss several examples of how the mislocalization of tumor suppressor proteins can lead to tumorigenesis.

\section{Inactivation of RB1 by mislocalization}

$R B 1$ is considered a classical TSG. The protein encoded by this gene is a negative regulator of the cell cycle. Inactivation of $R B 1$ through somatic mutation, deletion, or epigenetic silencing in various cancers is summarized in Table $2-9$. Hypophosphorylated pRB binds to and represses the transcriptional activity of E2F family members, which control the expression of genes necessary for cell cycle progression [43]. By contrast, $p R B$ that is serinephosphorylated by cyclin-dependent kinase 3 (CDK3)/cyclin-C has been shown to facilitate re-entry into the cell cycle by $\mathrm{G} 0$-arrested cells. pRB that is cytoplasmically mislocalized by exportin 1-mediated nuclear export may also promote tumor formation [44, 45]. In addition, some pRB-related proteins can also affect its subcellular localization. A-type nuclear lamins (lamin A/C), core components of the nuclear matrix, can tether $\mathrm{pRB}$ and lead to cell cycle arrest [46]. By contrast, co-expression of cyclin $E$ and simian vacuolating virus 40 (SV40) large T antigen inactivates pRB by disrupting its nuclear accumulation [47]. Another report reveals that pRB export from nucleus is regulated by its association with exportin-1, which is dependent on CDK-mediated phosphorylation of pRB at C-terminal phosphoresidues [48]. These data imply that nucleocytoplasmic mislocalization of pRB could be effectively reversed by inhibition of CDK activity. Thus, CDK inhibitors have tremendous clinical potential and promise in human cancer.

\section{Inactivation of TP53 by mislocalization}

p53 is a transcription factor (TF) that activates stress response genes involved in cell cycle checkpoints or cell death in response to DNA damage $[49,50]$. However, in several types of cancer (including colon cancer, breast cancer, ovarian cancer, retinoblastoma, and neuroblastoma), wild-type p53 is inactivated due to abnormal subcellular localization [51]. In these situations, the function and activity of p53 remains intact. p53 contains a nuclear import/ localization signal (NLS) and a nuclear export signal (NES) that mediate p53 translocation into the nucleus via nuclear transport receptors. For example, the function of p53 is also regulated by promyelocytic leukemia-nuclear bodies (PML-NBs) at the subnuclear level [52]. The PML protein forms a stable complex with p53 and cyclic AMP response element-binding protein (CREB) within PML-NBs and promotes p53 acetylation, which promotes apoptosis [53]. Loss of PML has been reported in many human cancers, so it is possible that functional inactivation of p53 could result from abnormal subcellular location induced by disruption of PML-NBs. In addition, several post-translational modifications of p53, such as sumoylation, glycosylation, neddylation, and ribosylation, also regulate p53 subcellular location [54]. p53 accumulation in the nucleus results in cell cycle arrest, senescence, and apoptosis. Thus, recent cancer treatment strategies attempted to induce wild type p53 nuclear retention or accumulation of p53 protein as a result of enhanced stabilization, resulting in apoptosis [55, 56].

\section{Inactivation of BRCA1 by mislocalization}

The familial breast cancer susceptibility gene BRCA1 encodes a $220 \mathrm{kDa}$ phosphorylatable $\mathrm{TF}$ with tumor suppressor activity. BRCA1 plays an important role in multiple biological pathways, including transcriptional regulation, proper genomic repair, cell proliferation, and apoptosis [57]. Reports of misregulation of BRCA1 through somatic mutation, deletion, or epigenetic silencing in various cancers are summarized in Table $2-9$. In addition, the subcellular localization of BRCA1 plays an important role in its tumor suppressor function. Many breast and ovarian cancer cell lines and primary tumors exhibit high levels of cytosolic BRCA1. The RING finger element of BRCA1 mediates nuclear import by association with its binding partner, BRCA1-associated RING domain protein 1 (BARD1) [58]. The structure of 
the BRCA1/BARD1 heterodimer predicts that the BRCA1 NES lies within the RING finger domain that mediates shuttling of BRCA1 into the cytoplasm [59]. This raised the possibility that BARD1 binding masks the NES at the N-terminus of BRCA1 and prevents association with chromosome region maintenance protein 1 (CRM1), thereby causing nuclear retention of BRCA1 [59]. Specifically, cancer-associated germline mutations in the C-terminus of BRCA1 restrict it to the cytosol and repress its nuclear function, particularly in response to DNA damage [57, 59, 60]. Furthermore, it is not known whether other RING finger domainbinding proteins such as BRCA1-associated protein 1 (BAP1) also interact with BRCA1 to inhibit its control of cell growth. In the context of cancer, studies into how the intracellular shuttling of BRCA 1 and its misregulation by somatic mutations alter its activity could provide insights into novel clinical applications.

\section{Inactivation of APC by mislocalization}

Loss of APC from mutation, epigenetic silencing, or hypermethylation of the promoter has been reported in many human cancers (Table $2-9$ ). This tumor suppressor is generally localized within the cytoplasm of healthy cells but has been shown to localize to the nucleus of human cancer cells [61], where it binds to and exports the oncogenic product $\beta$-catenin [62]. APC contains two classical NLSs and two functional NESs near the N-terminus that mediate shuttling between the nucleus and the cytoplasm by association with exportin-1 [63, 64]_ENREF_58. Direct regulation of APC during cell proliferation comes from casein kinase-2 (CK2), which binds to and phosphorylates APC at the N-terminus, resulting in its nuclear translocation [65]'[66]. In addition, the subcellular localization of APC is regulated by its binding partners. Other nuclear binding partners for APC are the protein tyrosine phosphatase PTP-BL, the TF activator protein- $2 \alpha$ (AP- $2 \alpha$ ), and the nuclear export factor exportin-1 [66]. Recent research in mouse models revealed that nuclear APC regulates epithelial cell proliferation by inhibiting canonical WNT signaling in intestinal tissue, suggesting that the subcellular distribution of APC plays an important role in cancer progression [67]. Several therapeutic treatment approaches aimed at restoring APC localization and its function in Wnt/ $\beta$-catenin signaling have been developed.

\section{Inactivation of SMAD4 by mislocalization}

Mothers against decapentaplegic homolog 4 (SMAD4) is a TSG associated with gastrointestinal carcinogenesis. As a member of the TGF- $\beta$ signaling family, SMAD4 is involved in many cell functions including differentiation, apoptosis, and cell cycle control $[68,69]$. In human cancers, the SMAD4 gene can be damaged by mutation or LOH or silenced by gene deletion (Table 2 - 9). Furthermore, abnormal subcellular distribution of SMAD4 may also result in loss of its function. A previous study demonstrated that, in unstimulated cells, the NLS in its MAD homology 1 (MH1) domain and the leucine-rich NES in its linker region are both constitutively active, with the result that SMAD4 is shuttled continuously between the nucleus and the cytoplasm [70]. Activation of the SMAD4 NES is dependent on exportin-1, while the export of SMAD2/3 from the nucleus is clearly independent of this factor [71]. Treatment of cells with the exportin-1 inhibitor leptomycin B (LMB) causes a rapid accumulation of SMAD4 in the nucleus, which confirms that SMAD4 is exported by this specific exportin [71]. In addition, certain retention factors, including microtubules [72] and nuclear import proteins such as the E26 transformation-specific (ETS)-related TFs (ELFs) $[73,74]$, have also been implicated in the regulation of the subcellular distribution of SMAD4. Previously, we found that, in advanced gastric carcinomas, $41 \%$ of samples that were negative for SMAD4 nuclear staining had moderate-to-high cytoplasmic SMAD4 staining. This pattern of SMAD4 accumulation correlated with cytoplasmic accumulation of SMAD2/3 [75]. Therefore, dysregulation of nuclecytoplasmic shuttling may be another mechanism leading to functional loss of nuclear SMAD4. 


\section{TF regulation}

TFs are key drivers of cell proliferation, and maintain the balance of expression of proapoptotic and anti-apoptotic genes. These factors typically bind to specific enhancer elements and/or other proteins of the transcriptional machinery, and can also recruit co-activators or co-repressors and RNA polymerase II directly, leading to expression or repression of key regulatory genes involved in tumorigenesis. Here, we provide a basic overview of a few TSGs that are inactivated by aberrant TF regulation.

\section{Inactivation of CDH1 by aberrant $T F$ regulation}

E-cadherin (CDH1) is a cell adhesion molecule that is essential in maintaining the integrity of cell-cell contacts in epithelial cell layers [76]. Loss of CDH1 enhances the invasiveness of epithelial tumor cells [77]. Dysregulation of CDH1 occurs in many human cancers, as a result of $C D H 1$ gene mutation, $\mathrm{LOH}$, or epigenetic promoter methylation (Table 2 - 9). Hypermethylation and chromatin remodeling of the $C D H 1$ gene have emerged as the main mechanisms responsible for the downregulation of $C D H 1$ in most carcinomas. It was recently reported that dysregulation of $\mathrm{CDH} 1$ expression also contributes to the progression of cancer. The Snail family TFs, including the zinc finger factors Snail and Slug, play a vital role in the transcriptional repression of $C D H 1$ and induce epithelial-mesenchymal transition (EMT) by altering gene transcription during the invasion process [77]. The two-handed zinc finger proteins ZEB1 and ZEB2 and the basic helix-loop-helix (bHLH) family proteins E12/E47 are also able to repress $C D H 1$ expression. TWIST1 is a transcriptional repressor of $C D H 1$, and an inverse correlation between TWIST1 and CDH1 expression has been reported in invasive lobular breast carcinoma [77]. These findings implicated TWIST1 in tumor cell intravasation, the process through which tumor cells enter into the circulation to seed metastases. More recently, another study demonstrated that the tumor suppressor Kruppellike factor 6 (KLF6) directly transactivates the CDH1 promoter [78]. These combined findings highlight multiple mechanisms through which aberrant TF regulation can lead to inactivation of the $C D H 1$ gene.

\section{Inactivation of PTEN by aberrant TF regulation}

Phosphatase and tensin homolog on chromosome 10 (PTEN) is a potent TSG located at chromosome 10q23.31. In many human cancers, PTEN is inactivated by mutation or epigenetic mechanisms, and PTEN protein stability or function can be weakened by other mechanisms $[79,80]$. Inactivation of PTEN by HD, LOH, point mutations, or aberrant methylation is summarized in Table $2-9$. However, in many cancers, the PTEN gene is intact, but appears to be transcriptionally silent. PTEN is a rapidly degraded protein with a half-life of less than 4 hours, and it appears that many of the genetic alterations found in PTEN in cancer cells further accelerate this rapid degradation. Sukhatme et al. found that the early growth response 1 (EGR1) TF binds directly to a consensus motif in the PTEN promoter and activates gene transcription, and is necessary for the upregulation of PTEN mRNA in response to UV light and other stress stimuli [81, 82]. In addition, Stambolic et al. demonstrated that PTEN transcription can also be induced by $\mathrm{p} 53$, which binds to a site in the promoter close to the EGR1-binding site [83]. The TP53 TSG is the most common functionally lost gene in human cancers. Moreover, several reports show that the APE1/Ref-1 pathway also regulates the expression of PTEN $[84,85]$. Therefore, it is possible that dysregulation of these TFs can inactivate PTEN function.

\section{Inactivation of KiSS1 by aberrant TF regulation}

KiSS1 was first identified as a TSG in melanoma. Lee et al. found that the expression of KiSS1 was negatively related to the metastasis potential of melanoma cell lines and clinical samples [86]. Later, the loss or downregulation of KiSS1 was found in various metastatic cancers, including ovarian cancer, endometrial cancer, gastric cancer, bladder cancer, brain cancer, and prostate cancer, which further verify its metastatic suppressor role in cancer 
progression [87]. The

LOH, promoter methylation, or gene mutation might be responsible for downregulation of it in part of tumor cases [87]. Besides the above genetic and epigenetic $\mathrm{r}$ e g u lat i o n, dys regulation of TF was also demonstrated to contribute the downregulation of KiSS1. Previous study showed that transcription factors, including TCF21, CUX1, YY1, EAP1, and TTF1, could regulate the expression of KiSS1 at mRNA level [88, 89]. Recent research showed that loss of TCF21 in metastatic

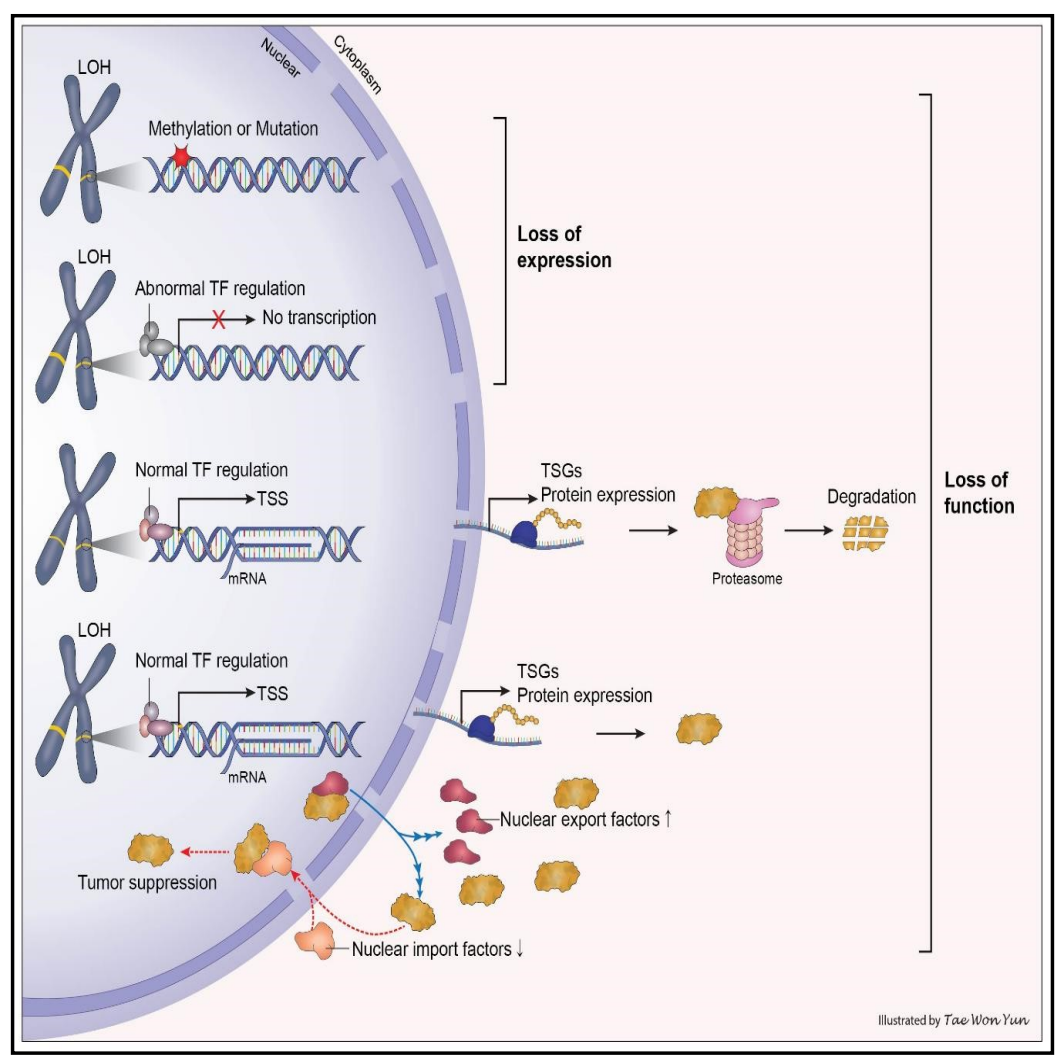

Fig. 1. A brief summary of "multiple hit" model for the loss of tumor suppressor gene function in human cancer. melanoma would result in the downregulation of KiSS1 and subsequently contribute to metastasis [88]. Furthermore, inactivation of CUX1 was also reported in acute myeloid leukemia [90]. Therefore, the above-mentioned data suggesting aberrant regulation of TFs would become an extra hit to inactivate KiSS1 gene. Hence, a better understanding of the multiple mechanisms that regulate TSG expression and their roles in cancer progression will enhance current treatment strategies.

\section{Conclusion}

Many reports demonstrate that the "two-hit" model, in which a genetic and an epigenetic event lead to loss of TSG expression, does not fully explain the inactivation of TSGs in human cancers. Therefore, we propose a revised "multiple-hit" model for the inactivation of TSGs, which includes a non-genetic/epigenetic event such as transcriptional regulation, proteasome degradation, or abnormal nucleocytoplasmic shuttling (Fig. 1). This revised "multiple-hit" model incorporates the inactivation of TSGs at the molecular level and could suggest novel targets for anti-cancer therapy. 


\section{Cellular Physiology Cell Physiol Biochem 2018;51:2647-2693 and Biochemistry Published $\begin{aligned} & \text { DOI: } 10.1159 / 000495956 \\ & \text { (c) } 2018 \text { The Author(s). Published by S. Karger AG, Basel } \\ & \text { www.karger.com/cpb }\end{aligned}$}

Wang et al.: Loss of Tumor Suppressor Genes Function

\section{Acknowledgements}

This work was supported by the National OncoVenture/National Cancer Center, funded by the Ministry of Health and Welfare, Republic of Korea (grant number: HI17C2196). This research was financially supported by Research Institute of Pharmaceutical Sciences, Seoul National University, Seoul and Logone Bioconvergence Research foundation, Seoul. The work was supported by the National Natural Science Foundation of China (No. 81572947, 81773216, 81773780).

All authors contributed significantly to the drafting and critical revision of this manuscript.

\section{Disclosure Statement}

The authors declare no competing interests.

\section{References}

1 Martincorena I, Campbell PJ: Somatic mutation in cancer and normal cells. Science 2015;349:1483-1489.

-2 Potapova TA, Zhu J, Li R: Aneuploidy and chromosomal instability: a vicious cycle driving cellular evolution and cancer genome chaos. Cancer Metast Rev 2013;32:377-389.

-3 Macaluso M, Paggi MG, Giordano A: Genetic and epigenetic alterations as hallmarks of the intricate road to cancer. Oncogene 2003;22:6472-6478.

4 Baxter E, Windloch K, Gannon F, Lee JS: Epigenetic regulation in cancer progression. Cell Biosci 2014;4:45.

-5 McDuff FK, Turner SD: Jailbreak: oncogene-induced senescence and its evasion. Cell Signal 2011;23:6-13.

6 Sun W, Yang J: Functional mechanisms for human tumor suppressors. J Cancer 2010;1:136-140.

7 Vattemi E, Claudio PP: Tumor suppressor genes as cancer therapeutics. Drug news \& perspectives 2007;20:511-520.

8 Leiderman YI, Kiss S, Mukai S: Molecular genetics of RB1--the retinoblastoma gene. Seminars in ophthalmology 2007;22:247-254.

9 Smith AL, Robin TP, Ford HL: Molecular pathways: targeting the TGF-beta pathway for cancer therapy. Clin Cancer Res 2012;18:4514-4521.

10 Savage KI, Harkin DP: BRCA1, a 'complex' protein involved in the maintenance of genomic stability. The FEBS journal 2015;282:630-646.

11 Nayak SK, Panesar PS, Kumar H: p53-Induced apoptosis and inhibitors of p53. Cur Med Chem 2009;16:2627-2640.

12 Rahman N, Scott RH: Cancer genes associated with phenotypes in monoallelic and biallelic mutation carriers: new lessons from old players. Hum Mol Genet 2007;16 Spec No 1:R60-66.

13 Tomlinson IP, Lambros MB, Roylance RR: Loss of heterozygosity analysis: practically and conceptually flawed? Genes, Chromosomes Cancer 2002;34:349-353.

14 Balmain A, Gray J, Ponder B: The genetics and genomics of cancer. Nat Genet 2003;33 Suppl:238-244.

$>15$ Esteller M: Epigenetics in cancer. N Engl J Med 2008;358:1148-1159.

-16 Esteller M, Corn PG, Baylin SB, Herman JG: A gene hypermethylation profile of human cancer. Cancer Res 2001;61:3225-3229.

17 Kitagawa K, Kotake Y, Kitagawa M: Ubiquitin-mediated control of oncogene and tumor suppressor gene products. Cancer Sci 2009;100:1374-1381.

18 Peller S, Rotter V: TP53 in hematological cancer: low incidence of mutations with significant clinical relevance. Hum Mut 2003;21:277-284.

19 Brachman DG, Graves D, Vokes E, Beckett M, Haraf D, Montag A, Dunphy E, Mick R, Yandell D, Weichselbaum RR: Occurrence of p53 gene deletions and human papilloma virus infection in human head and neck cancer. Cancer Res 1992;52:4832-4836.

20 Hock AK, Vousden KH: The role of ubiquitin modification in the regulation of p53. Biochim. Biophys Acta 2014;1843:137-149. 


\section{Cellular Physiology Cell Physiol Biochem 2018;51:2647-2693 and Biochemistry \begin{tabular}{l|l} 
DOI: 10.1159/000495956 & (c)18 The Author(s). Published by S. Karger AG, Basel \\
\hline
\end{tabular}

-21 Pei D, Zhang Y, Zheng J: Regulation of p53: a collaboration between Mdm2 and Mdmx. Oncotarget 2012;3:228-235.

-22 Kon N, Kobayashi Y, Li M, Brooks CL, Ludwig T, Gu W: Inactivation of HAUSP in vivo modulates p53 function. Oncogene 2010;29:1270-1279.

23 Marine JC: Spotlight on the role of COP1 in tumorigenesis. Nat Rev Cancer 2012;12:455-464.

-24 Jung YS, Qian Y, Chen X: Pirh2 RING-finger E3 ubiquitin ligase: its role in tumorigenesis and cancer therapy. FEBS Lett 2012;586:1397-1402.

-25 Zhang X, Berger FG, Yang J, Lu X: USP4 inhibits p53 through deubiquitinating and stabilizing ARF-BP1. EMBO J 2011;30:2177-2189.

-26 Yang Y, Kitagaki J, Wang H, Hou DX, Perantoni AO: Targeting the ubiquitin-proteasome system for cancer therapy. Cancer Sci 2009;100:24-28.

27 Onel K, Cordon-Cardo C: MDM2 and prognosis. Mol Cancer Res 2004;2:1-8.

-28 Laurie NA, Donovan SL, Shih CS, Zhang J, Mills N, Fuller C, Teunisse A, Lam S, Ramos Y, Mohan A, Johnson D, Wilson M, Rodriguez-Galindo C, Quarto M, Francoz S, Mendrysa SM, Guy RK, Marine JC, Jochemsen AG, Dyer MA: Inactivation of the p53 pathway in retinoblastoma. Nature 2006;444:61-66.

29 Scheffner M, Huibregtse JM, Vierstra RD, Howley PM: The HPV-16 E6 and E6-AP complex functions as a ubiquitin-protein ligase in the ubiquitination of p53 Cell 1993;75:495-505.

30 Rajasekaran N, Jung HS, Bae SH, Chelakkot C, Hong S, Choi JS, Yim DS, Oh YK, Choi YL, Shin YK: Effect of HPV E6/E7 siRNA with Chemotherapeutic Agents on the Regulation of TP53/E2F Dynamic Behavior for Cell Fate Decisions. Neoplasia 2017;19:735-749.

-31 Quelle DE, Zindy F, Ashmun RA, Sherr CJ: Alternative reading frames of the INK4a tumor suppressor gene encode two unrelated proteins capable of inducing cell cycle arrest. Cell 1995;83:993-1000.

-32 Robertson KD, Jones PA: Tissue-specific alternative splicing in the human INK4a/ARF cell cycle regulatory locus. Oncogene 1999;18:3810-3820.

-33 Lin YC, Diccianni MB, Kim Y, Lin HH, Lee CH, Lin RJ, Joo SH, Li J, Chuang TJ, Yang AS, Kuo HH, Tsai MD, Yu AL: Human p16gamma, a novel transcriptional variant of p16(INK4A), coexpresses with p16(INK4A) in cancer cells and inhibits cell-cycle progression. Oncogene 2007;26:7017-7027.

34 Zhang Y, Xiong Y, Yarbrough WG: ARF promotes MDM2 degradation and stabilizes p53: ARF-INK4a locus deletion impairs both the Rb and p53 tumor suppression pathways. Cell 1998;92:725-734.

35 Li J, Poi MJ, Tsai MD: Regulatory mechanisms of tumor suppressor P16(INK4A) and their relevance to cancer. Biochemistry 2011;50:5566-5582.

36 Vivo M, Matarese M, Sepe M, Di Martino R, Festa L, Calabro V, La Mantia G, Pollice A: MDM2mediated degradation of p14ARF: a novel mechanism to control ARF levels in cancer cells. PLoS One 2015;10:e0117252.

37 Agrawal A, Yang J, Murphy RF, Agrawal DK: Regulation of the p14ARF-Mdm2-p53 pathway: an overview in breast cancer. Exp Mol Pathol 2006;81:115-122.

-38 Neuzillet C, Tijeras-Raballand A, Cohen R, Cros J, Faivre S, Raymond E, de Gramont A: Targeting the TGFbeta pathway for cancer therapy. Pharmacology \& therapeutics 2015;147:22-31.

-39 Inoue Y, Imamura T: Regulation of TGF-beta family signaling by E3 ubiquitin ligases. Cancer Sci 2008;99:2107-2112.

40 Imamura T, Oshima Y, Hikita A: Regulation of TGF-beta family signalling by ubiquitination and deubiquitination. J Biochem 2013;154:481-489.

-41 Fabbro M, Henderson BR: Regulation of tumor suppressors by nuclear-cytoplasmic shuttling. Exp Cell Res 2003;282:59-69.

42 Wang SC, Hung MC: Cytoplasmic/nuclear shuttling and tumor progression. An NY Acad Sci 2005;1059:1115.

43 Barbie DA, Conlan LA, Kennedy BK: Nuclear tumor suppressors in space and time. Trends in Cell Biol 2005;15:378-385.

44 Jiao W, Lin HM, Datta J, Braunschweig T, Chung JY, Hewitt SM, Rane SG: Aberrant nucleocytoplasmic localization of the retinoblastoma tumor suppressor protein in human cancer correlates with moderate/ poor tumor differentiation. Oncogene 2008;27:3156-3164.

-45 Ren S, Rollins BJ: Cyclin C/cdk3 promotes Rb-dependent G0 exit. Cell 2004;117:239-251. 


\section{Cellular Physiology Cell Physiol Biochem 2018;51:2647-2693 \begin{tabular}{l|l|l} 
and Biochemistry Published online: 12 December 2018 & $\begin{array}{l}\text { (c) } 2018 \text { The Author(s). Published by S. Karger AG, Basel } \\
\text { www.karger.com/cpb }\end{array}$ \\
\hline
\end{tabular}}

Wang et al.: Loss of Tumor Suppressor Genes Function

46 Johnson BR, Nitta RT, Frock RL, Mounkes L, Barbie DA, Stewart CL, Harlow E, Kennedy BK: A-type lamins regulate retinoblastoma protein function by promoting subnuclear localization and preventing proteasomal degradation. Proc Natl Acad Sci U S A2004;101:9677-9682.

47 Angus SP, Solomon DA, Kuschel L, Hennigan RF, Knudsen ES: Retinoblastoma tumor suppressor: analyses of dynamic behavior in living cells reveal multiple modes of regulation. Mol Cell Biol 2003;23:8172-8188.

48 Jiao W, Datta J, Lin HM, Dundr M, Rane SG: Nucleocytoplasmic shuttling of the retinoblastoma tumor suppressor protein via Cdk phosphorylation-dependent nuclear export. J Biol Chem 2006;281:3809838108.

49 Rufini A, Tucci P, Celardo I, Melino G: Senescence and aging: the critical roles of p53 Oncogene 2013;32:5129-5143.

50 Riley T, Sontag E, Chen P, Levine A: Transcriptional control of human p53-regulated genes. Nat Rev Mol Cell Biol 2008;9:402-412.

-51 Hill R, Cautain B, de Pedro N, Link W: Targeting nucleocytoplasmic transport in cancer therapy. Oncotarget 2014;5:11-28.

52 Sahin U, de The H, Lallemand-Breitenbach V: PML nuclear bodies: assembly and oxidative stress-sensitive sumoylation. Nucleus 2014;5:499-507.

53 Pearson M, Carbone R, Sebastiani C, Cioce M, Fagioli M, Saito S, Higashimoto Y, Appella E, Minucci S, Pandolfi PP, Pelicci PG: PML regulates p53 acetylation and premature senescence induced by oncogenic Ras. Nature 2000;406:207-210.

54 Hollstein M, Hainaut P: Massively regulated genes: the example of TP53 J Pathol 2010;220:164-173.

-55 Xu GW, Mawji IA, Macrae CJ, Koch CA, Datti A, Wrana JL, Dennis JW, Schimmer AD: A high-content chemical screen identifies ellipticine as a modulator of p53 nuclear localization. Apoptosis 2008;13:413-422.

-56 Kastenhuber ER, Lowe SW: Putting p53 in Context. Cell 2017;170:1062-1078.

57 Jiang Q, Greenberg RA: Deciphering the BRCA1 Tumor Suppressor Network. J Biol Chem 2015;290:1772417732.

58 Zhang YQ, Bianco A, Malkinson AM, Leoni VP, Frau G, De Rosa N, Andre PA, Versace R, Boulvain M, Laurent GJ, Atzori L, Irminger-Finger I: BARD1: an independent predictor of survival in non-small cell lung cancer. Int J Cancer 2012;131:83-94.

59 Brzovic PS, Rajagopal P, Hoyt DW, King MC, Klevit RE: Structure of a BRCA1-BARD1 heterodimeric RINGRING complex. Nat Struct Biol 2001;8:833-837.

60 Rodriguez JA, Au WW, Henderson BR: Cytoplasmic mislocalization of BRCA1 caused by cancer-associated mutations in the BRCT domain. Exp Cell Res 2004;293:14-21.

61 Henderson BR: Nuclear-cytoplasmic shuttling of APC regulates beta-catenin subcellular localization and turnover. Nat Cell Biol 2000;2:653-660.

-62 Sharma M, Johnson M, Brocardo M, Jamieson C, Henderson BR: Wnt signaling proteins associate with the nuclear pore complex: implications for cancer. Adv Exp Med Biol 2014;773:353-372.

-63 Stade K, Ford CS, Guthrie C, Weis K: Exportin 1 (Crm1p) is an essential nuclear export factor. Cell 1997;90:1041-1050.

64 Gorlich D: Transport into and out of the cell nucleus. The EMBO journal 1998;17:2721-2727.

-65 Zhang F, White RL, Neufeld KL: Cell density and phosphorylation control the subcellular localization of adenomatous polyposis coli protein. Mol Cellul Biol 2001;21:8143-8156.

66 Neufeld KL: Nuclear APC. Adv Exp Med Biol 2009;656:13-29.

-67 Zeineldin M, Cunningham J, McGuinness W, Alltizer P, Cowley B, Blanchat B, Xu W, Pinson D, Neufeld KL: A knock-in mouse model reveals roles for nuclear Apc in cell proliferation, Wnt signal inhibition and tumor suppression. Oncogene 2012;31:2423-2437.

68 Xia X, Wu W, Huang C, Cen G, Jiang T, Cao J, Huang K, Qiu Z: SMAD4 and its role in pancreatic cancer. Tumour Biol 2015;36:111-119.

69 Miyaki M, Kuroki T: Role of Smad4 (DPC4) inactivation in human cancer. Biochem Bioph Res Co 2003;306:799-804.

-70 Pierreux CE, Nicolas FJ, Hill CS: Transforming growth factor beta-independent shuttling of Smad4 between the cytoplasm and nucleus. Mol Cellular Biol 2000;20:9041-9054.

-71 Inman GJ, Nicolas FJ, Hill CS: Nucleocytoplasmic shuttling of Smads 2, 3, and 4 permits sensing of TGF-beta receptor activity. Molecular Cell 2002;10:283-294. 


\section{Cellular Physiology Cell Physiol Biochem 2018;51:2647-2693 and Biochemistry Published \begin{tabular}{l|l} 
DOI: 10.1159/000495956 & $\begin{array}{l}\text { (c) } 2018 \text { The Author(s). Published by S. Karger AG, Basel } \\
\text { www.karger.com/cpb }\end{array}$
\end{tabular}}

Wang et al.: Loss of Tumor Suppressor Genes Function

72 Dong C, Li Z, Alvarez R, Jr., Feng XH, Goldschmidt-Clermont PJ: Microtubule binding to Smads may regulate TGF beta activity. Molecular Cell 2000;5:27-34.

73 Tang Y, Katuri V, Dillner A, Mishra B, Deng CX, Mishra L: Disruption of transforming growth factor-beta signaling in ELF beta-spectrin-deficient mice. Science 2003;299:574-577.

-74 Katuri V, Tang Y, Marshall B, Rashid A, Jogunoori W, Volpe EA, Sidawy AN, Evans S, Blay J, Gallicano GI, Premkumar Reddy E, Mishra L, Mishra B: Inactivation of ELF/TGF-beta signaling in human gastrointestinal cancer. Oncogene 2005;24:8012-8024.

-75 Wang LH, Kim SH, Lee JH, Choi YL, Kim YC, Park TS, Hong YC, Wu CF, Shin YK: Inactivation of SMAD4 tumor suppressor gene during gastric carcinoma progression. Clin Cancer Res 2007;13:102-110.

-76 van Roy F: Beyond E-cadherin: roles of other cadherin superfamily members in cancer. Nat Rev Cancer 2014;14:121-134.

77 Liu YN, Lee WW, Wang CY, Chao TH, Chen Y, Chen JH: Regulatory mechanisms controlling human E-cadherin gene expression. Oncogene 2005;24:8277-8290.

78 DiFeo A, Narla G, Camacho-Vanegas O, Nishio H, Rose SL, Buller RE, Friedman SL, Walsh MJ, Martignetti JA: E-cadherin is a novel transcriptional target of the KLF6 tumor suppressor. Oncogene 2006;25:6026-6031.

79 Hopkins BD, Parsons RE: Molecular pathways: intercellular PTEN and the potential of PTEN restoration therapy. Clin Cancer Res 2014;20:5379-5383.

80 Bermudez Brito M, Goulielmaki E, Papakonstanti EA: Focus on PTEN Regulation. Frontiers in oncology 2015;5:166.

81 Sukhatme VP, Cao XM, Chang LC, Tsai-Morris CH, Stamenkovich D, Ferreira PC, Cohen DR, Edwards SA, Shows TB, Curran T, ML Beau, ED Adamson.: A zinc finger-encoding gene coregulated with c-fos during growth and differentiation, and after cellular depolarization. Cell 1988;53:37-43.

-82 Yu J, Zhang SS, Saito K, Williams S, Arimura Y, Ma Y, Ke Y, Baron V, Mercola D, Feng GS, Adamson E, Mustelin T: PTEN regulation by Akt-EGR1-ARF-PTEN axis. The EMBO journal 2009;28:21-33.

-83 Stambolic V, MacPherson D, Sas D, Lin Y, Snow B, Jang Y, Benchimol S, Mak TW: Regulation of PTEN transcription by p53 Molecular Cell 2001;8:317-325.

84 Fantini D, Vascotto C, Deganuto M, Bivi N, Gustincich S, Marcon G, Quadrifoglio F, Damante G, Bhakat KK, Mitra S, Tell G: APE1/Ref-1 regulates PTEN expression mediated by Egr-1 Free Radical Res 2008;42:20-29.

-85 Cesaratto L, Calligaris SD, Vascotto C, Deganuto M, Bellarosa C, Quadrifoglio F, Ostrow JD, Tiribelli C, Tell G: Bilirubin-induced cell toxicity involves PTEN activation through an APE1/Ref-1-dependent pathway. J Molec Med 2007;85:1099-1112.

-86 Lee JH, Miele ME, Hicks DJ, Phillips KK, Trent JM, Weissman BE, Welch DR: KiSS-1, a novel human malignant melanoma metastasis-suppressor gene. J Natl Cancer Inst 1996;88:1731-1737.

87 Ji K, Ye L, Mason MD, Jiang WG: The Kiss-1/Kiss-1R complex as a negative regulator of cell motility and cancer metastasis (Review). Int J Mol Med 2013;32:747-754.

-88 Arab K, Smith LT, Gast A, Weichenhan D, Huang JP, Claus R, Hielscher T, Espinosa AV, Ringel MD, Morrison CD, Schadendorf D, Kumar R, Plass C: Epigenetic deregulation of TCF21 inhibits metastasis suppressor KISS1 in metastatic melanoma. Carcinogenesis 2011;32:1467-1473.

89 Semaan SJ, Kauffman AS: Emerging concepts on the epigenetic and transcriptional regulation of the Kiss1 gene. Int J Dev Neurosci 2013;31:452-462.

-90 McNerney ME, Brown CD, Wang X, Bartom ET, Karmakar S, Bandlamudi C, Yu S, Ko J, Sandall BP, Stricker T, Anastasi J, Grossman RL, Cunningham JM, Le Beau MM, White KP: CUX1 is a haploinsufficient tumor suppressor gene on chromosome 7 frequently inactivated in acute myeloid leukemia. Blood 2013;121:975983.

91 Nakai H, Misawa S: Chromosome 17 abnormalities and inactivation of the p53 gene in chronic myeloid leukemia and their prognostic significance. Leukemia \& lymphoma 1995;19:213-221.

-92 Chiaretti S, Tavolaro S, Marinelli M, Messina M, Del Giudice I, Mauro FR, Santangelo S, Piciocchi A, Peragine N, Truong S, Patten N, Ghia EM, Torrente I, De Propris MS, Nanni M, Lawrence J, Guarini A, Foa R: Evaluation of TP53 mutations with the AmpliChip p53 research test in chronic lymphocytic leukemia: correlation with clinical outcome and gene expression profiling. Genes, Chromosomes Cancer 2011;50:263-274.

-93 Agirre X, Novo FJ, Calasanz MJ, Larrayoz MJ, Lahortiga I, Valganon M, Garcia-Delgado M, Vizmanos JL: TP53 is frequently altered by methylation, mutation, and/or deletion in acute lymphoblastic leukaemia. Mol Carcinogen 2003;38:201-208. 


\section{Cellular Physiology Cell Physiol Biochem 2018;51:2647-2693 and Biochemistry \begin{tabular}{l|l} 
DOI: 10.1159/000495956 & $\begin{array}{l}\text { (c) } 2018 \text { The Author(s). Published by S. Karger AG, Basel } \\
\text { www.karger.com/cpb }\end{array}$
\end{tabular}}

Wang et al.: Loss of Tumor Suppressor Genes Function

$\$ 94$ Haapasalo H, Isola J, Sallinen P, Kalimo H, Helin H, Rantala I: Aberrant p53 expression in astrocytic neoplasms of the brain: association with proliferation. Am J Pathol 1993;142:1347-1351.

-95 Jung HL, Wang KC, Kim SK, Sung KW, Koo HH, Shin HY, Ahn HS, Shin HJ, Cho BK: Loss of heterozygosity analysis of chromosome 17p13.1-13.3 and its correlation with clinical outcome in medulloblastomas. J Neuro-oncol 2004;67:41-46.

$\$ 96$ Jin W, Xu X, Yang T, Hua Z: p53 mutation, EGFR gene amplification and loss of heterozygosity on chromosome 10,17 p in human gliomas. Chinese Medical Journal 2000;113:662-666.

\$7 Orellana C, Hernandez-Marti M, Martinez F, Castel V, Millan JM, Alvarez-Garijo JA, Prieto F, Badia L: Pediatric brain tumors: loss of heterozygosity at $17 \mathrm{p}$ and TP53 gene mutations. Cancer genetics and cytogenetics 1998;102:93-99.

-98 Kato H, Kato S, Kumabe T, Sonoda Y, Yoshimoto T, Kato S, Han SY, Suzuki T, Shibata H, Kanamaru R, Ishioka C: Functional evaluation of p53 and PTEN gene mutations in gliomas. Clin Cancer Res 2000;6:3937-3943.

$\$ 99$ Almeida LO, Custodio AC, Pinto GR, Santos MJ, Almeida JR, Clara CA, Rey JA, Casartelli C: Polymorphisms and DNA methylation of gene TP53 associated with extra-axial brain tumors. Genetics and Molecular Res 2009;8:8-18.

100 Sharpless NE: INK4a/ARF: a multifunctional tumor suppressor locus. Mutation research 2005;576:22-38.

101 Rocco JW, Sidransky D: p16(MTS-1/CDKN2/INK4a) in cancer progression. Exp Cell Res 2001;264:42-55.

102 Liu Y, Szekely L, Grander D, Soderhall S, Juliusson G, Gahrton G, Linder S, Einhorn S: Chronic lymphocytic leukemia cells with allelic deletions at 13q14 commonly have one intact RB1 gene: evidence for a role of an adjacent locus. Proc Natl Acad Sci U S A 1993;90:8697-8701.

103 Lens D, Matutes E, Catovsky D, Coignet LJ: Frequent deletions at 11q23 and 13q14 in B cell prolymphocytic leukemia (B-PLL). Leukemia 2000;14:427-430.

104 Melo MB, Costa FF, Saad ST, Lorand-Metze I, Bordin S, Ahmad NN: Molecular analysis of the retinoblastoma (RB1) gene in acute myeloid leukemia patients. Leukemia Res 1998;22:787-792.

105 Ogino A, Yoshino A, Katayama Y, Watanabe T, Ota T, Komine C, Yokoyama T, Fukushima T: The p15(INK4b)/ p16(INK4a)/RB1 pathway is frequently deregulated in human pituitary adenomas. Journal of neuropathology and experimental neurology 2005;64:398-403.

106 Barnholtz-Sloan J, Sloan AE, Land S, Kupsky W, Monteiro AN: Somatic alterations in brain tumors. Oncol Rep 2008;20:203-210.

107 Gonzalez-Gomez P, Bello MJ, Alonso ME, Arjona D, Lomas J, de Campos JM, Isla A, Rey JA: CpG island methylation status and mutation analysis of the RB1 gene essential promoter region and protein-binding pocket domain in nervous system tumours. British J Cancer 2003;88:109-114.

108 Gao Y, Li L, Song L: Expression of p16 and Survivin in gliomas and their correlation with cell proliferation. Oncol Lett 2015;10:301-306.

109 Ohgaki H, Kleihues P: Genetic pathways to primary and secondary glioblastoma. Am J Pathol 2007;170:1445-1453.

110 Cividin M, Ayrault O, Sorel N, Seite P, Brizard F, Blanchet O, Mahon FX, Guilhot F, Larsen C, Chomel JC, Brizard A: Expression of the cell cycle regulators p14(ARF) and p16(INK4a) in chronic myeloid leukemia. Leukemia Res 2006;30:1273-1278.

111 Faderl S, Kantarjian HM, Estey E, Manshouri T, Chan CY, Rahman Elsaied A, Kornblau SM, Cortes J, Thomas DA, Pierce S, Keating MJ, Estrov Z, Albitar M: The prognostic significance of p16(INK4a)/p14(ARF) locus deletion and MDM-2 protein expression in adult acute myelogenous leukemia. Cancer 2000;89:1976-1982.

112 Nagy E, Beck Z, Kiss A, Csoma E, Telek B, Konya J, Olah E, Rak K, Toth FD: Frequent methylation of p16INK4A and p14ARF genes implicated in the evolution of chronic myeloid leukaemia from its chronic to accelerated phase. Eur J Cancer 2003;39:2298-2305.

113 Roman-Gomez J, Jimenez-Velasco A, Castillejo JA, Agirre X, Barrios M, Navarro G, Molina FJ, Calasanz MJ, Prosper F, Heiniger A, Torres A: Promoter hypermethylation of cancer-related genes: a strong independent prognostic factor in acute lymphoblastic leukemia. Blood 2004;104:2492-2498.

114 Yang Y, Takeuchi S, Hofmann WK, Ikezoe T, van Dongen JJ, Szczepanski T, Bartram CR, Yoshino N, Taguchi H, Koeffler HP: Aberrant methylation in promoter-associated $\mathrm{CpG}$ islands of multiple genes in acute lymphoblastic leukemia. Leukemia Res 2006;30:98-102.

115 Nakamura M, Watanabe T, Klangby U, Asker C, Wiman K, Yonekawa Y, Kleihues P, Ohgaki H: p14ARF deletion and methylation in genetic pathways to glioblastomas. Brain Pathol 2001;11:159-168. 


\section{Cellular Physiology Cell Physiol Biochem 2018;51:2647-2693 \begin{tabular}{l|l|l} 
and Biochemistry Publisned onlIne: 12 December 2018 & $\begin{array}{l}\text { ○ } 2018 \text { The Author(s). Published by S. Karger AG, Basel } \\
\text { www.karger.com/cpb }\end{array}$ \\
\hline
\end{tabular}}

Wang et al.: Loss of Tumor Suppressor Genes Function

116 Yin D, Xie D, Hofmann WK, Miller CW, Black KL, Koeffler HP: Methylation, expression, and mutation analysis of the cell cycle control genes in human brain tumors. Oncogene 2002;21:8372-8378.

117 Zhang SJ, Endo S, Saito T, Kouno M, Kuroiwa T, Washiyama K, Kumanishi T: Primary malignant lymphoma of the brain: frequent abnormalities and inactivation of p14 tumor suppressor gene. Cancer Sci 2005;96:3841.

118 Tort F, Hernandez S, Bea S, Martinez A, Esteller M, Herman JG, Puig X, Camacho E, Sanchez M, Nayach I, Lopez-Guillermo A, Fernandez PL, Colomer D, Hernandez L, Campo E: CHK2-decreased protein expression and infrequent genetic alterations mainly occur in aggressive types of non-Hodgkin lymphomas. Blood 2002;100:4602-4608.

-119 Hofmann WK, Miller CW, Tsukasaki K, Tavor S, Ikezoe T, Hoelzer D, Takeuchi S, Koeffler HP: Mutation analysis of the DNA-damage checkpoint gene CHK2 in myelodysplastic syndromes and acute myeloid leukemias. Leukemia Res 2001;25:333-338.

120 Humbert M, Halter V, Shan D, Laedrach J, Leibundgut EO, Baerlocher GM, Tobler A, Fey MF, Tschan MP: Deregulated expression of Kruppel-like factors in acute myeloid leukemia. Leukemia Res 2011;35:909-913.

121 Chen PY, Yen JH, Kao RH, Chen JH: Down-regulation of the oncogene PTTG1 via the KLF6 tumor suppressor during induction of myeloid differentiation. PloS one 2013;8:e71282.

122 Camacho-Vanegas O, Narla G, Teixeira MS, DiFeo A, Misra A, Singh G, Chan AM, Friedman SL, Feuerstein BG, Martignetti JA: Functional inactivation of the KLF6 tumor suppressor gene by loss of heterozygosity and increased alternative splicing in glioblastoma. Int J Cancer 2007;121:1390-1395.

123 Jeng YM, Hsu HC: KLF6, a putative tumor suppressor gene, is mutated in astrocytic gliomas. Int J Cancer 2003;105:625-629.

124 Vax VV, Gueorguiev M, Dedov, II, Grossman AB, Korbonits M: The Kruppel-like transcription factor 6 gene in sporadic pituitary tumours. Endocrine-related cancer 2003;10:397-402.

125 Kohler B, Wolter M, Blaschke B, Reifenberger G: Absence of mutations in the putative tumor suppressor gene KLF6 in glioblastomas and meningiomas.Int J Cancer 2004;111:644-645.

126 Garcia-Orti L, Cristobal I, Cirauqui C, Guruceaga E, Marcotegui N, Calasanz MJ, Castello-Cros R, Odero MD: Integration of SNP and mRNA arrays with microRNA profiling reveals that MiR-370 is upregulated and targets NF1 in acute myeloid leukemia. PloS one 2012;7:e47717.

127 Lu D, Nounou R, Beran M, Estey E, Manshouri T, Kantarjian H, Keating MJ, Albitar M: The prognostic significance of bone marrow levels of neurofibromatosis-1 protein and ras oncogene mutations in patients with acute myeloid leukemia and myelodysplastic syndrome. Cancer 2003;97:441-449.

128 Steinemann D, Arning L, Praulich I, Stuhrmann M, Hasle H, Stary J, Schlegelberger B, Niemeyer CM, Flotho C: Mitotic recombination and compound-heterozygous mutations are predominant NF1-inactivating mechanisms in children with juvenile myelomonocytic leukemia and neurofibromatosis type 1 Haematologica 2010;95:320-323.

129 Nakai H, Misawa S, Horiike S, Taniwaki M, Seriu T, Shimazaki C, Fujii H, Maekawa T, Furukawa T, Abe T, et al.: Analysis of mutations and expression of GAP-related domain of the neurofibromatosis type 1 (NF1) gene in the progression of chronic myelogenous leukemia. Leukemia 1994;8:1027-1033.

130 Thiel G, Marczinek K, Neumann R, Witkowski R, Marchuk DA, Nurnberg P: Somatic mutations in the neurofibromatosis 1 gene in gliomas and primitive neuroectodermal tumours. Anticancer Res 1995;15:2495-2499.

131 Tenan M, Colombo BM, Cajola L, Pollo B, Broggi G, Finocchiaro G: Low frequency of NF1 gene mutations in malignant gliomas. Eur J Cancer 1993;29A:1217-1218.

132 Yang Y, Takeuchi S, Tsukasaki K, Yamada Y, Hata T, Mori N, Fukushima A, Seo H, Koeffler HP, Taguchi H: Methylation analysis of the adenomatous polyposis coli (APC) gene in adult T-cell leukemia/lymphoma. Leukemia Res 2005;29:47-51.

133 Sun C, Yamato T, Kondo E, Furukawa T, Ikeda H, Horii A: Infrequent mutation of APC, AXIN1, and GSK3B in human pituitary adenomas with abnormal accumulation of CTNNB1. J Neuro-oncol 2005;73:131-134.

134 Pecina-Slaus N, Nikuseva Martic T, Zeljko M, Bulat S: Brain metastases exhibit gross deletions of the APC gene. Brain Tumor Pathol 2011;28:223-228.

135 Yu J, Zhang H, Gu J, Lin S, Li J, Lu W, Wang Y, Zhu J: Methylation profiles of thirty four promoter-CpG islands and concordant methylation behaviours of sixteen genes that may contribute to carcinogenesis of astrocytoma. BMC Cancer 2004;4:65. 


\section{Cellular Physiology Cell Physiol Biochem 2018:51:2647-2693 and Biochemistry \begin{tabular}{l|l} 
DOI: $10.1159 / 000495956$ & (c) 2018 The Author(s). Published by S. Karger AG, Basel \\
mublisher. 2018
\end{tabular}

Wang et al.: Loss of Tumor Suppressor Genes Function

136 Parry L, Maynard JH, Patel A, Hodges AK, von Deimling A, Sampson JR, Cheadle JP: Molecular analysis of the TSC1 and TSC2 tumour suppressor genes in sporadic glial and glioneuronal tumours. Hum Genet 2000;107:350-356.

137 Becker AJ, Lobach M, Klein H, Normann S, Nothen MM, von Deimling A, Mizuguchi M, Elger CE, Schramm J, Wiestler OD, Blumcke I: Mutational analysis of TSC1 and TSC2 genes in gangliogliomas. Neuropathol Appl Neurobiol 2001;27:105-114.

138 Inokuchi K, Yamaguchi H, Hanawa H, Tanosaki S, Nakamura K, Tarusawa M, Miyake K, Shimada T, Dan K: Loss of DCC gene expression is of prognostic importance in acute myelogenous leukemia. Clin Cancer Res 2002;8:1882-1888.

139 Porfiri E: DCC (deleted in colorectal cancer) inactivation in hematological malignancies. Leukemia \& lymphoma 1995;18:69-72.

140 Miyake K, Inokuchi K, Dan K, Nomura T: Alterations in the deleted in colorectal carcinoma gene in human primary leukemia. Blood 1993;82:927-930.

141 Wada C, Shionoya S, Fujino Y, Tokuhiro H, Akahoshi T, Uchida T, Ohtani H: Genomic instability of microsatellite repeats and its association with the evolution of chronic myelogenous leukemia. Blood 1994;83:3449-3456.

142 Scheck AC, Coons SW: Expression of the tumor suppressor gene DCC in human gliomas. Cancer Res 1993;53:5605-5609.

143 Ekstrand BC, Mansfield TA, Bigner SH, Fearon ER: DCC expression is altered by multiple mechanisms in brain tumours. Oncogene 1995;11:2393-2402.

144 Podszywalow-Bartnicka P, Wolczyk M, Kusio-Kobialka M, Wolanin K, Skowronek K, Nieborowska-Skorska M, Dasgupta Y, Skorski T, Piwocka K: Downregulation of BRCA1 protein in BCR-ABL1 leukemia cells depends on stress-triggered TIAR-mediated suppression of translation. Cell cycle 2014;13:3727-3741.

145 Galetzka D, Hansmann T, El Hajj N, Weis E, Irmscher B, Ludwig M, Schneider-Ratzke B, Kohlschmidt N, Beyer V, Bartsch O, Zechner U, Spix C, Haaf T: Monozygotic twins discordant for constitutive BRCA1 promoter methylation, childhood cancer and secondary cancer. Epigenetics 2012;7:47-54.

146 Boukerroucha M, Josse C, Segers K, El-Guendi S, Freres P, Jerusalem G, Bours V: BRCA1 germline mutation and glioblastoma development: report of cases. BMC cancer 2015;15:181.

147 Diouf B, Cheng Q, Krynetskaia NF, Yang W, Cheok M, Pei D, Fan Y, Cheng C, Krynetskiy EY, Geng H, Chen S, Thierfelder WE, Mullighan CG, Downing JR, Hsieh P, Pui CH, Relling MV, Evans WE: Somatic deletions of genes regulating MSH2 protein stability cause DNA mismatch repair deficiency and drug resistance in human leukemia cells. Nat Med 2011;17:1298-1303.

148 Wang CX, Wang X, Liu HB, Zhou ZH: Aberrant DNA methylation and epigenetic inactivation of hMSH2 decrease overall survival of acute lymphoblastic leukemia patients via modulating cell cycle and apoptosis. Asian Pac J Cancer P 2014;15:355-362.

149 Srivastava T, Chattopadhyay P, Mahapatra AK, Sarkar C, Sinha S: Increased hMSH2 protein expression in glioblastoma multiforme. J Neuro-oncol 2004;66:51-57.

150 Leung SY, Chan TL, Chung LP, Chan AS, Fan YW, Hung KN, Kwong WK, Ho JW, Yuen ST: Microsatellite instability and mutation of DNA mismatch repair genes in gliomas. Am J Pathol 1998;153:1181-1188.

151 Griffiths EA, Gore SD, Hooker CM, Mohammad HP, McDevitt MA, Smith BD, Karp JE, Herman JG, Carraway HE: Epigenetic differences in cytogenetically normal versus abnormal acute myeloid leukemia. Epigenetics 2010;5:590-600.

152 Gomori E, Pal J, Meszaros I, Doczi T, Matolcsy A: Epigenetic inactivation of the hMLH1 gene in progression of gliomas. Diagnostic molecular pathology, part B 2007;16:104-107.

153 Zou ZJ, Fan L, Wang L, Xu J, Zhang R, Tian T, Li JY, Xu W: miR-26a and miR-214 down-regulate expression of the PTEN gene in chronic lymphocytic leukemia, but not PTEN mutation or promoter methylation. Oncotarget 2015;6:1276-1285.

154 Leupin N, Cenni B, Novak U, Hugli B, Graber HU, Tobler A, Fey MF: Disparate expression of the PTEN gene: a novel finding in B-cell chronic lymphocytic leukaemia (B-CLL). British J Haematol 2003;121:97-100.

155 Liu TC, Lin PM, Chang JG, Lee JP, Chen TP, Lin SF: Mutation analysis of PTEN/MMAC1 in acute myeloid leukemia. Am J Hematol 2000;63:170-175.

156 Chang H, Qi XY, Claudio J, Zhuang L, Patterson B, Stewart AK: Analysis of PTEN deletions and mutations in multiple myeloma. Leukemia Res 2006;30:262-265. 
157 Baeza N, Weller M, Yonekawa Y, Kleihues P, Ohgaki H: PTEN methylation and expression in glioblastomas. Acta neuropathologica 2003;106:479-485.

158 Huang J, Chen H, Wei Q, Zhang Z, Zhong Z, Xu Y: Downregulation of LKB1 promotes tumor progression and predicts unfavorable prognosis in patients with glioma. Oncol Lett 2017;13:1688-1694.

159 Sobottka SB, Haase M, Fitze G, Hahn M, Schackert HK, Schackert G: Frequent loss of heterozygosity at the 19p13.3 locus without LKB1/STK11 mutations in human carcinoma metastases to the brain. J Neuro-oncol 2000;49:187-195.

160 Strathdee G: Epigenetic versus genetic alterations in the inactivation of E-cadherin. Seminars in cancer biology 2002;12:373-379.

161 Nikuseva-Martic T, Beros V, Pecina-Slaus N, Pecina HI, Bulic-Jakus F: Genetic changes of CDH1, APC, and CTNNB1 found in human brain tumors. Pathology, research and practice 2007;203:779-787.

162 D’Urso PI, D’Urso OF, Storelli C, Catapano G, Gianfreda CD, Montinaro A, Muscella A, Marsigliante S: Retrospective protein expression and epigenetic inactivation studies of $\mathrm{CDH} 1$ in patients affected by lowgrade glioma. J Neuro-oncol 2011;104:113-118.

163 Chen Y, Lu L, Wang L: [Study on gene expression of TGF beta 1 and its receptor in leukemia cells and the serum TGF beta 1 level in the patients with acute leukemia]. Zhonghua xue ye xue za zhi = Zhonghua xueyexue zazhi 1998;19:576-580.

164 Pineau P, Marchio A, Cordina E, Tiollais P, Dejean A: Homozygous deletions scanning in tumor cell lines detects previously unsuspected loci. Int J Cancer 2003;106:216-223.

165 D’Abronzo FH, Swearingen B, Klibanski A, Alexander JM: Mutational analysis of activin/transforming growth factor-beta type I and type II receptor kinases in human pituitary tumors. J Clin Endocrinol Metab 1999;84:1716-1721.

166 Rooke HM, Vitas MR, Crosier PS, Crosier KE: The TGF-beta type II receptor in chronic myeloid leukemia: analysis of microsatellite regions and gene expression. Leukemia 1999;13:535-541.

167 Molenaar JJ, Gerard B, Chambon-Pautas C, Cave H, Duval M, Vilmer E, Grandchamp B: Microsatellite instability and frameshift mutations in BAX and transforming growth factor-beta RII genes are very uncommon in acute lymphoblastic leukemia in vivo but not in cell lines. Blood 1998;92:230-233.

168 Izumoto S, Arita N, Ohnishi T, Hiraga S, Taki T, Tomita N, Ohue M, Hayakawa T: Microsatellite instability and mutated type II transforming growth factor-beta receptor gene in gliomas. Cancer Lett 1997;112:251-256.

169 Kaneko H, Horiike S, Sasai Y, Iwai T, Nakao M, Yokota S, Taniwaki M, Kashima K, Misawa S: Rare alteration of genomic structure or expression of the DPC4 gene in myelogenous leukemias. Acta haematologica 1998;99:187-190.

170 Buschges R, Bostrom J, Wolter M, Blaschke B, Weber RG, Lichter P, Collins VP, Reifenberger G: Analysis of human meningiomas for aberrations of the MADH2, MADH4, APM-1 and DCC tumor suppressor genes on the long arm of chromosome 18 Int J Cancer 2001;92:551-554.

171 Ikezoe T, Takeuchi S, Kamioka M, Daibata M, Kubonishi I, Taguchi H, Miyoshi I: Analysis of the Smad2 gene in hematological malignancies. Leukemia 1998;12:94-95.

172 Wieser R, Gruber B, Rieder H, Fonatsch C: Mutational analysis of the tumor suppressor Smad2 in acute lymphoid and myeloid leukemia. Leukemia 1998;12:1114-1118.

173 Pukkila MJ, Kumpulainen EJ, Virtaniemi JA, Johansson RT, Halonen PM, Kellokoski JK, Kosunen AS, Nuutinen J, Kosma VM: Nuclear and cytoplasmic p53 expression in pharyngeal squamous cell carcinoma: prognostic implications. Head \& neck 2002;24:784-791.

174 Rodrigo Tapia JP, Gonzalez Meana MV, Garcia Gonzalez LA, Coto E, Garcia Pedrero J, Nunez Batalla F, Suarez Nieto C: [Inactivation of p53 and amplification of cyclin D1 in squamous cell carcinomas of the head and neck]. Acta otorrinolaringologica espanola 2002;53:225-232.

175 Largey JS, Meltzer SJ, Yin J, Norris K, Sauk JJ, Archibald DW: Loss of heterozygosity of p53 in oral cancers demonstrated by the polymerase chain reaction. Cancer 1993;71:1933-1937.

176 Wichmann G, Rosolowski M, Krohn K, Kreuz M, Boehm A, Reiche A, Scharrer U, Halama D, Bertolini J, Bauer U, Holzinger D, Pawlita M, Hess J, Engel C, Hasenclever D, Scholz M, Ahnert P, Kirsten H, Hemprich A, Wittekind C et al.: The role of HPV RNA transcription, immune response-related gene expression and disruptive TP53 mutations in diagnostic and prognostic profiling of head and neck cancer. Int J Cancer 2015;137:2846-2857.

177 Mattioni M, Soddu S, Prodosmo A, Visca P, Conti S, Alessandrini G, Facciolo F, Strigari L: Prognostic role of serum p53 antibodies in lung cancer. BMC cancer 2015;15:148. 


\section{Cellular Physiology Cell Physiol Biochem 2018;51:2647-2693 \begin{tabular}{ll|l} 
and Biochemistry Published onlIne: 12 December 2018 & $\begin{array}{l}\text { (c) } 2018 \text { The Author(s). Published by S. Karger AG, Basel } \\
\text { www.karger.com/cpb }\end{array}$ \\
\hline
\end{tabular}}

178 Bian C, Li Z, Xu Y, Wang J, Xu L, Shen H: Clinical outcome and expression of mutant P53, P16, and Smad4 in lung adenocarcinoma: a prospective study. World J Surg Oncol 2015;13:128.

179 Girard L, Zochbauer-Muller S, Virmani AK, Gazdar AF, Minna JD: Genome-wide allelotyping of lung cancer identifies new regions of allelic loss, differences between small cell lung cancer and non-small cell lung cancer, and loci clustering. Cancer Res 2000;60:4894-4906.

180 Karlsson A, Brunnstrom H, Lindquist KE, Jirstrom K, Jonsson M, Rosengren F, Reutersward C, Cirenajwis H, Borg A, Jonsson P, Planck M, Jonsson G, Staaf J: Mutational and gene fusion analyses of primary large cell and large cell neuroendocrine lung cancer. Oncotarget 2015;6:22028-22037.

-181 Woodson K, Mason J, Choi SW, Hartman T, Tangrea J, Virtamo J, Taylor PR, Albanes D: Hypomethylation of p53 in peripheral blood DNA is associated with the development of lung cancer. Cancer epidemiology, biomarkers \& prevention 2001;10:69-74.

182 Bai S, Zhang X, Wang J: [Loss of heterozygosity on chromosome 13 in squamous cell carcinomas of the larynx]. Zhonghua zhong liu za zhi [Chinese journal of oncology] 1997;19:35-37.

183 Ogawara K, Miyakawa A, Shiba M, Uzawa K, Watanabe T, Wang XL, Sato T, Kubosawa H, Kondo Y, Tanzawa $\mathrm{H}$ : Allelic loss of chromosome 13q14.3 in human oral cancer: correlation with lymph node metastasis. Int J Cancer 1998;79:312-317.

184 Sabir M, Baig RM, Ali K, Mahjabeen I, Saeed M, Kayani MA: Retinoblastoma (RB1) pocket domain mutations and promoter hyper-methylation in head and neck cancer. Cellular oncology 2014;37:203-213.

185 Xu HJ, Quinlan DC, Davidson AG, Hu SX, Summers CL, Li J, Benedict WF: Altered retinoblastoma protein expression and prognosis in early-stage non-small-cell lung carcinoma. Journal of the National Cancer Institute 1994;86:695-699.

186 Tamura K, Zhang X, Murakami Y, Hirohashi S, Xu HJ, Hu SX, Benedict WF, Sekiya T: Deletion of three distinct regions on chromosome 13q in human non-small-cell lung cancer. Int J Cancer 1997;74:45-49.

187 Weber A, Wittekind C, Tannapfel A: Genetic and epigenetic alterations of 9p21 gene products in benign and malignant tumors of the head and neck. Pathology, research and practice 2003;199:391-397.

188 Guo M, Alumkal J, Drachova T, Gao D, Marina SS, Jen J, Herman JG: CHFR methylation strongly correlates with methylation of DNA damage repair and apoptotic pathway genes in non-small cell lung cancer. Discovery medicine 2015;19:151-158.

189 Zhang CY, Jin YT, Xu HY, Zhang H, Zhang WM, Sun XY, Tan C, Chen CM: [Relationship between promoter methylation of p16, DAPK and RAR beta genes and the clinical data of non-small cell lung cancer]. Zhonghua yi xue yi chuan xue za zhi = Zhonghua yixue yichuanxue zazhi = Chinese journal of medical genetics 2011;28:23-28.

190 Gruttgen A, Reichenzeller M, Junger M, Schlien S, Affolter A, Bosch FX: Detailed gene expression analysis but not microsatellite marker analysis of 9p21 reveals differential defects in the INK4a gene locus in the majority of head and neck cancers. J Pathol 2001;194:311-317.

191 Kishi M, Nakamura M, Nishimine M, Ikuta M, Kirita T, Konishi N: Genetic and epigenetic alteration profiles for multiple genes in salivary gland carcinomas. Oral Oncol 2005;41:161-169.

$\checkmark 192$ Lo KW, Huang DP: Genetic and epigenetic changes in nasopharyngeal carcinoma. Seminars in cancer biology 2002;12:451-462.

193 Shintani S, Nakahara Y, Mihara M, Ueyama Y, Matsumura T: Inactivation of the p14(ARF), p15(INK4B) and p16(INK4A) genes is a frequent event in human oral squamous cell carcinomas. Oral Oncol 2001;37:498504.

194 Sailasree R, Abhilash A, Sathyan KM, Nalinakumari KR, Thomas S, Kannan S: Differential roles of p16INK4A and p14ARF genes in prognosis of oral carcinoma. Cancer epidemiology, biomarkers \& prevention 2008;17:414-420.

195 Cortot AB, Younes M, Martel-Planche G, Guibert B, Isaac S, Souquet PJ, Commo F, Girard P, Fouret P, Brambilla E, Hainaut P, Soria JC: Mutation of TP53 and alteration of p14(arf) expression in EGFR- and KRAS-mutated lung adenocarcinomas. Clinical lung cancer 2014;15:124-130.

196 Park MJ, Shimizu K, Nakano T, Park YB, Kohno T, Tani M, Yokota J: Pathogenetic and biologic significance of TP14ARF alterations in nonsmall cell lung carcinoma. Cancer genetics and cytogenetics 2003;141:5-13.

197 Ozenne P, Eymin B, Brambilla E, Gazzeri S: The ARF tumor suppressor: structure, functions and status in cancer. Int J Cancer 2010;127:2239-2247.

198 Zhang P, Wang J, Gao W, Yuan BZ, Rogers J, Reed E: CHK2 kinase expression is down-regulated due to promoter methylation in non-small cell lung cancer. Mol Cancer 2004;3:14. 


\section{Cellular Physiology Cell Physiol Biochem 2018;51:2647-2693

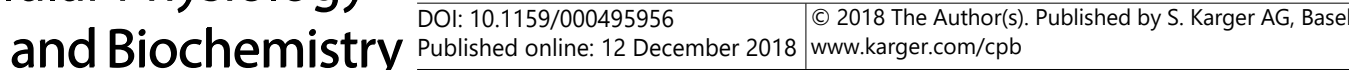

Wang et al.: Loss of Tumor Suppressor Genes Function

199 Haruki N, Saito H, Tatematsu Y, Konishi H, Harano T, Masuda A, Osada H, Fujii Y, Takahashi T: Histological type-selective, tumor-predominant expression of a novel CHK1 isoform and infrequent in vivo somatic CHK2 mutation in small cell lung cancer. Cancer Res 2000;60:4689-4692.

200 Teixeira MS, Camacho-Vanegas O, Fernandez Y, Narla G, DiFeo A, Lee B, Kalir T, Friedman SL, Schlecht NF, Genden EM, Urken M, Brandwein-Gensler M, Martignetti JA: KLF6 allelic loss is associated with tumor recurrence and markedly decreased survival in head and neck squamous cell carcinoma. Int J Cancer 2007;121:1976-1983.

201 Chen HK, Liu XQ Lin J, Chen TY, Feng QS, Zeng YX: [Mutation analysis of KLF6 gene in human nasopharyngeal carcinomas]. Ai zheng = Aizheng = Chinese journal of cancer 2002;21:1047-1050.

202 Ito G, Uchiyama M, Kondo M, Mori S, Usami N, Maeda O, Kawabe T, Hasegawa Y, Shimokata K, Sekido Y: Kruppel-like factor 6 is frequently down-regulated and induces apoptosis in non-small cell lung cancer cells. Cancer Res 2004;64:3838-3843.

203 Furukawa K, Yanai N, Fujita M, Harada Y: Novel mutations of neurofibromatosis type 1 gene in small cell lung cancers. Surgery today 2003;33:323-327.

204 Uesugi H, Uzawa K, Kawasaki K, Shimada K, Moriya T, Tada A, Shiiba M, Tanzawa H: Status of reduced expression and hypermethylation of the APC tumor suppressor gene in human oral squamous cell carcinoma. Int J Mol Med 2005;15:597-602.

205 Sakata K: Alterations of tumor suppressor genes and the H-ras oncogene in oral squamous cell carcinoma. J Oral Pathol Med 1996;25:302-307.

206 Zeki K, Spambalg D, Sharifi N, Gonsky R, Fagin JA: Mutations of the adenomatous polyposis coli gene in sporadic thyroid neoplasms. J Clin Endocrinol Metab 1994;79:1317-1321.

207 Gao S, Eiberg H, Krogdahl A, Liu CJ, Sorensen JA: Cytoplasmic expression of E-cadherin and beta-Catenin correlated with LOH and hypermethylation of the APC gene in oral squamous cell carcinomas. J Oral Pathol Med 2005;34:116-119.

208 Noorlag R, van Kempen PM, Moelans CB, de Jong R, Blok LE, Koole R, Grolman W, van Diest PJ, van Es RJ, Willems SM: Promoter hypermethylation using 24-gene array in early head and neck cancer: better outcome in oral than in oropharyngeal cancer. Epigenetics 2014;9:1220-1227.

209 Sanz-Ortega J, Bryant B, Sanz-Esponera J, Asenjo JA, Saez MC, Torres A, Balibrea JL, Sobel ME, Merino MJ: $\mathrm{LOH}$ at the APC/MCC gene $(5 \mathrm{Q} 21)$ is frequent in early stages of non-small cell lung cancer. Pathol Res Pract 1999;195:677-680.

210 Ohgaki H, Kros JM, Okamoto Y, Gaspert A, Huang H, Kurrer MO: APC mutations are infrequent but present in human lung cancer. Cancer Lett 2004;207:197-203.

211 Gao L, Xie E, Yu T, Chen D, Zhang L, Zhang B, Wang F, Xu J, Huang P, Liu X, Fang B, Pan S: Methylated APC and RASSF1A in multiple specimens contribute to the differential diagnosis of patients with undetermined solitary pulmonary nodules. J Thorac Dis 2015;7:422-432.

212 Chakraborty S, Mohiyuddin SM, Gopinath KS, Kumar A: Involvement of TSC genes and differential expression of other members of the mTOR signaling pathway in oral squamous cell carcinoma. BMC Cancer 2008;8:163.

213 Takamochi K, Ogura T, Yokose T, Ochiai A, Nagai K, Nishiwaki Y, Suzuki K, Esumi H: Molecular analysis of the TSC1 gene in adenocarcinoma of the lung. Lung cancer 2004;46:271-281.

214 Venugopalan M, Wood TF, Wilczynski SP, Sen S, Peters J, Ma GC, Evans GA, Srivatsan ES: Loss of heterozygosity in squamous cell carcinomas of the head and neck defines a tumor suppressor gene region on 11q13. Cancer Genet Cytogenet 1998;104:124-132.

215 Kaur J, Demokan S, Tripathi SC, Macha MA, Begum S, Califano JA, Ralhan R: Promoter hypermethylation in Indian primary oral squamous cell carcinoma. Int J Cancer 2010;127:2367-2373.

-216 Longo AL, Rettori MM, de Carvalho AC, Kowalski LP, Carvalho AL, Vettore AL: Evaluation of the methylation profile of exfoliated cell samples from patients with head and neck squamous cell carcinoma. Head \& Neck 2014;36:631-637.

217 Zhang J, Ding F, Wang X: [Expression and loss of heterozygosity of DCC gene in human lung cancer]. Zhonghua yi xue za zhi 1995; 75:211-213, 254-215.

218 Kohno T, Sato T, Takakura S, Takei K, Inoue K, Nishioka M, Yokota J: Mutation and expression of the DCC gene in human lung cancer. Neoplasia 2000;2:300-305.

219 An Q Liu Y, Gao Y, Huang J, Fong X, Liu L, Zhang D, Zhang J, Cheng S: Deletion of tumor suppressor genes in Chinese non-small cell lung cancer. Cancer Lett 2002;184:189-195. 
220 Vora HH, Shah NG, Patel DD, Trivedi TI, Choksi TJ: BRCA1 expression in leukoplakia and carcinoma of the tongue. J Surg Oncol 2003;83:232-240.

221 Feldman R, Gatalica Z, Knezetic J, Reddy S, Nathan CA, Javadi N, Teknos T: Molecular profiling of head and neck squamous cell carcinoma. Head \& Neck 2016;38 Suppl 1:E1625-1638.

222 Wang LR, He LJ, Wang Y, Li YY, Lou Y, Zhang GB, Li Y, Chen J: Correlation between BRCA1 and TopBP1 protein expression and clinical outcome of non-small cell lung cancer treated with platinum-based chemotherapy. Cancer Chemoth Pharmacol 2015;76:163-170.

223 Marks JL, Golas B, Kirchoff T, Miller VA, Riely GJ, Offit K, Pao W: EGFR mutant lung adenocarcinomas in patients with germline BRCA mutations. J Thoracic Oncol 2008;3:805.

224 Harada H, Miyamoto K, Yamashita Y, Nakano K, Taniyama K, Miyata Y, Ohdan H, Okada M: Methylation of breast cancer susceptibility gene 1 (BRCA1) predicts recurrence in patients with curatively resected stage I non-small cell lung cancer. Cancer 2013;119:792-798.

225 Nunn J, Nagini S, Risk JM, Prime W, Maloney P, Liloglou T, Jones AS, Rogers SR, Gosney JR, Woolgar J, Field JK: Allelic imbalance at the DNA mismatch repair loci, hMSH2, hMLH1, hPMS1, hPMS2 and hMSH3, in squamous cell carcinoma of the head and neck. Oral Oncol 2003;39:115-129.

226 Wang Y, Irish J, MacMillan C, Brown D, Xuan Y, Boyington C, Gullane P, Kamel-Reid S: High frequency of microsatellite instability in young patients with head-and-neck squamous-cell carcinoma: lack of involvement of the mismatch repair genes hMLH1 AND hMSH2 Int J Cancer 2001;93:353-360.

227 Czerninski R, Krichevsky S, Ashhab Y, Gazit D, Patel V, Ben-Yehuda D: Promoter hypermethylation of mismatch repair genes, hMLH1 and hMSH2 in oral squamous cell carcinoma. Oral diseases 2009;15:206213.

228 Xie KJ, He HE, Sun AJ, Liu XB, Sun LP, Dong XJ: Expression of ERCC1, MSH2 and PARP1 in non-small cell lung cancer and prognostic value in patients treated with platinum-based chemotherapy. Asian Pac J Cancer $\mathrm{P}$ 2014;15:2591-2596.

229 Xinarianos G, Liloglou T, Prime W, Maloney P, Callaghan J, Fielding P, Gosney JR, Field JK: hMLH1 and hMSH2 expression correlates with allelic imbalance on chromosome $3 p$ in non-small cell lung carcinomas. Cancer Res 2000;60:4216-4221.

230 Wang YC, Lu YP, Tseng RC, Lin RK, Chang JW, Chen JT, Shih CM, Chen CY: Inactivation of hMLH1 and hMSH2 by promoter methylation in primary non-small cell lung tumors and matched sputum samples. J Clin Investigation 2003;111:887-895.

231 Tawfik HM, El-Maqsoud NM, Hak BH, El-Sherbiny YM: Head and neck squamous cell carcinoma: mismatch repair immunohistochemistry and promoter hypermethylation of hMLH1 gene. Am J Otolaryngol 2011;32:528-536.

232 Giudice FS, Squarize CH: The determinants of head and neck cancer: Unmasking the PI3K pathway mutations. J carcinogenesis \& mutagenesis 2013;Suppl 5

233 Ji Y, Zheng M, Ye S, Chen J, Chen Y: PTEN and Ki67 expression is associated with clinicopathologic features of non-small cell lung cancer. J Biomed Res 2014;28:462-467.

234 Marsit CJ, Zheng S, Aldape K, Hinds PW, Nelson HH, Wiencke JK, Kelsey KT: PTEN expression in non-smallcell lung cancer: evaluating its relation to tumor characteristics, allelic loss, and epigenetic alteration. Hum pathol 2005;36:768-776.

235 Dearden S, Stevens J, Wu YL, Blowers D: Mutation incidence and coincidence in non small-cell lung cancer: meta-analyses by ethnicity and histology (mutMap). Ann Oncol 2013;24:2371-2376.

236 Kline ER, Muller S, Pan L, Tighiouart M, Chen ZG, Marcus AI: Localization-specific LKB1 loss in head and neck squamous cell carcinoma metastasis. Head \& Neck 2011;33:1501-1512.

237 Qiu W, Schonleben F, Thaker HM, Goggins M, Su GH: A novel mutation of STK11/LKB1 gene leads to the loss of cell growth inhibition in head and neck squamous cell carcinoma. Oncogene 2006;25:2937-2942.

238 Makowski L, Hayes DN: Role of LKB1 in lung cancer development. British J cancer 2008;99:683-688.

239 Gill RK, Yang SH, Meerzaman D, Mechanic LE, Bowman ED, Jeon HS, Roy Chowdhuri S, Shakoori A, Dracheva T, Hong KM, Fukuoka J, Zhang JH, Harris CC, Jen J: Frequent homozygous deletion of the LKB1/STK11 gene in non-small cell lung cancer. Oncogene 2011;30:3784-3791.

240 Zhang W, Gao Y, Li F, Tong X, Ren Y, Han X, Yao S, Long F, Yang Z, Fan H, Zhang L, Ji H: YAP promotes malignant progression of Lkb1-deficient lung adenocarcinoma through downstream regulation of survivin. Cancer Res 2015;75:4450-4457. 


\section{Cellular Physiology Cell Physiol Biochem 2018;51:2647-2693

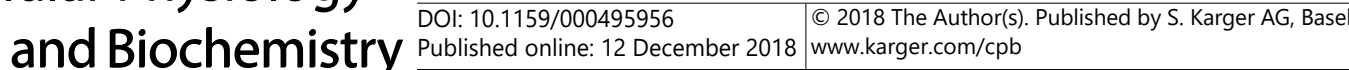

Wang et al.: Loss of Tumor Suppressor Genes Function

-241 Sanchez-Cespedes M, Parrella P, Esteller M, Nomoto S, Trink B, Engles JM, Westra WH, Herman JG, Sidransky D: Inactivation of LKB1/STK11 is a common event in adenocarcinomas of the lung. Cancer Res 2002;62:3659-3662.

242 Fei Q, Zhang H, Chen X, Wang JC, Zhang R, Xu W, Zhang Z, Zou W, Zhang K, Qi Q Wang M, Tao S, Luo Z: Defected expression of E-cadherin in non-small cell lung cancer. Lung Cancer 2002;37:147-152.

243 Kafka A, Tomas D, Beros V, Pecina HI, Zeljko M, Pecina-Slaus N: Brain metastases from lung cancer show increased expression of DVL1, DVL3 and beta-catenin and down-regulation of E-cadherin. Int J Mol Sci 2014;15:10635-10651.

244 Safar AM, Spencer H, 3rd, Su X, Coffey M, Cooney CA, Ratnasinghe LD, Hutchins LF, Fan CY: Methylation profiling of archived non-small cell lung cancer: a promising prognostic system. Clin Cancer Res 2005;11:4400-4405.

245 Toyooka S, Toyooka KO, Maruyama R, Virmani AK, Girard L, Miyajima K, Harada K, Ariyoshi Y, Takahashi T, Sugio K, Brambilla E, Gilcrease M, Minna JD, Gazdar AF: DNA methylation profiles of lung tumors. Mol Cancer therapeutics 2001;1:61-67.

246 Paterson IC, Matthews JB, Huntley S, Robinson CM, Fahey M, Parkinson EK, Prime SS: Decreased expression of TGF-beta cell surface receptors during progression of human oral squamous cell carcinoma. J Pathol 2001;193:458-467.

247 Munoz-Antonia T, Torrellas-Ruiz M, Clavell J, Mathews LA, Muro-Cacho CA, Baez A: Aberrant methylation inactivates transforming growth factor Beta receptor I in head and neck squamous cell carcinoma. Int J Otolaryngol 2009;2009:848695.

248 Harn HJ, Fan HC, Chen CJ, Tsai NM, Yen CY, Huang SC: Microsatellite alteration at chromosome 11 in primary human nasopharyngeal carcinoma in Taiwan. Oral Oncol 2002;38:23-29.

-249 White RA, Malkoski SP, Wang XJ: TGFbeta signaling in head and neck squamous cell carcinoma. Oncogene 2010;29:5437-5446.

250 Zhao J, Liu Z, Li W, Liu X, Chen XF, Zhang HT: Infrequently methylated event at sites -362 to -142 in the promoter of TGF beta R1 gene in non-small cell lung cancer. J Cancer Res Clinic Oncol 2008;134:919-925.

251 Tani M, Takenoshita S, Kohno T, Hagiwara K, Nagamachi Y, Harris CC, Yokota J: Infrequent mutations of the transforming growth factor beta-type II receptor gene at chromosome 3p22 in human lung cancers with chromosome 3p deletions. Carcinogenesis 1997;18:1119-1121.

252 Kim WS, Park C, Hong SK, Park BK, Kim HS, Park K: Microsatellite instability(MSI) in non-small cell lung cancer(NSCLC) is highly associated with transforming growth factor-beta type II receptor(TGF-beta RII) frameshift mutation. Anticancer Res 2000;20:1499-1502.

253 Gemma A, Uematsu K, Hagiwara K, Takenoshita S, Kudoh S: [Mechanism of resistance to growth inhibition by transforming growth factor-beta 1 (TGF-beta 1) in primary lung cancer and new molecular targets in therapy]. Gan To Kagaku Ryoho 2000;27:1253-1259.

254 Zhang HT, Chen XF, Wang MH, Wang JC, Qi QY, Zhang RM, Xu WQ, Fei QY, Wang F, Cheng QQ Chen F, Zhu CS, Tao SH, Luo Z: Defective expression of transforming growth factor beta receptor type II is associated with CpG methylated promoter in primary non-small cell lung cancer. Clin Cancer Res 2004;10:2359-2367.

255 Xie W, Aisner S, Baredes S, Sreepada G, Shah R, Reiss M: Alterations of Smad expression and activation in defining 2 subtypes of human head and neck squamous cell carcinoma. Head \& Neck 2013;35:76-85.

256 Xie W, Bharathy S, Kim D, Haffty BG, Rimm DL, Reiss M: Frequent alterations of Smad signaling in human head and neck squamous cell carcinomas: a tissue microarray analysis. Oncol Res 2003;14:61-73.

257 Kim SK, Fan Y, Papadimitrakopoulou V, Clayman G, Hittelman WN, Hong WK, Lotan R, Mao L: DPC4, a candidate tumor suppressor gene, is altered infrequently in head and neck squamous cell carcinoma. Cancer Res 1996;56:2519-2521.

258 Malkoski SP, Wang XJ: Two sides of the story? Smad4 loss in pancreatic cancer versus head-and-neck cancer. FEBS Lett 2012;586:1984-1992.

259 Nagatake M, Takagi Y, Osada H, Uchida K, Mitsudomi T, Saji S, Shimokata K, Takahashi T, Takahashi T: Somatic in vivo alterations of the DPC4 gene at 18q21 in human lung cancers. Cancer Res 1996;56:27182720.

260 Muro-Cacho CA, Rosario-Ortiz K, Livingston S, Munoz-Antonia T: Defective transforming growth factor beta signaling pathway in head and neck squamous cell carcinoma as evidenced by the lack of expression of activated Smad2. Clin Cancer Res 2001;7:1618-1626. 


\section{Cellular Physiology Cell Physiol Biochem 2018;51:2647-2693 \begin{tabular}{ll|l} 
and Biochemistry Published onlIne: 12 December 2018 & $\begin{array}{l}\text { (c) } 2018 \text { The Author(s). Published by S. Karger AG, Basel } \\
\text { www.karger.com/cpb }\end{array}$ \\
\hline
\end{tabular}}

Wang et al.: Loss of Tumor Suppressor Genes Function

-261 Shen JL, Yan CH, Liu Y, Yan XQ Zhang XL, Jin Y, Zhang KF, Sang ZF, Zhang GY, Li P, Fu SB: [Studies of TGFbeta/Smads expression in lung cancer]. Yi chuan xue bao = Acta genetica Sinica 2003;30:681-686.

-262 Riggins GJ, Kinzler KW, Vogelstein B, Thiagalingam S: Frequency of Smad gene mutations in human cancers. Cancer Res 1997;57:2578-2580.

263 Yao W, Qin X, Qi B, Lu J, Guo L, Liu F, Liu S, Zhao B: Association of p53 expression with prognosis in patients with esophageal squamous cell carcinoma. Int J Clinical and Exp Pathol 2014;7:7158-7163.

264 Meltzer SJ, Yin J, Huang Y, McDaniel TK, Newkirk C, Iseri O, Vogelstein B, Resau JH: Reduction to homozygosity involving p53 in esophageal cancers demonstrated by the polymerase chain reaction. Proc Natl Acad Sci U S A 1991;88:4976-4980.

-265 Huang Y, Boynton RF, Blount PL, Silverstein RJ, Yin J, Tong Y, McDaniel TK, Newkirk C, Resau JH, Sridhara R, Reid BJ, Meltzer SJ: Loss of heterozygosity involves multiple tumor suppressor genes in human esophageal cancers. Cancer Res 1992;52:6525-6530.

-266 Kandioler D, Schoppmann SF, Zwrtek R, Kappel S, Wolf B, Mittlbock M, Kuhrer I, Hejna M, Pluschnig U, BaSsalamah A, Wrba F, Zacherl J: The biomarker TP53 divides patients with neoadjuvantly treated esophageal cancer into 2 subgroups with markedly different outcomes. A p53 Research Group study. The Journal of thoracic and cardiovascular surgery 2014;148:2280-2286.

267 Fenoglio-Preiser CM, Wang J, Stemmermann GN, Noffsinger A: TP53 and gastric carcinoma: a review. Hum Mutat 2003;21:258-270.

-268 Busuttil RA, Zapparoli GV, Haupt S, Fennell C, Wong SQ Pang JM, Takeno EA, Mitchell C, Di Costanzo N, Fox S, Haupt Y, Dobrovic A, Boussioutas A: Role of p53 in the progression of gastric cancer. Oncotarget 2014;5:12016-12026.

269 Harada H, Tanaka H, Shimada Y, Shinoda M, Imamura M, Ishizaki K: Lymph node metastasis is associated with allelic loss on chromosome 13q12-13 in esophageal squamous cell carcinoma. Cancer Res 1999;59:3724-3729.

270 Gao YB, Chen ZL, Li JG, Hu XD, Shi XJ, Sun ZM, Zhang F, Zhao ZR, Li ZT, Liu ZY, Zhao YD, Sun J, Zhou CC, Yao R, Wang SY, Wang P, Sun N, Zhang BH, Dong JS, Yu Y et al.: Genetic landscape of esophageal squamous cell carcinoma. Nat Genet 2014;46:1097-1102.

271 Ling Y, Huang G, Fan L, Wei L, Zhu J, Liu Y, Zhu C, Zhang C: CpG island methylator phenotype of cell-cycle regulators associated with TNM stage and poor prognosis in patients with oesophageal squamous cell carcinoma. J Clin Pathol 2011;64:246-251.

272 Constancia M, Seruca R, Carneiro F, Silva F, Castedo S: Retinoblastoma gene structure and product expression in human gastric carcinomas. British J Cancer 1994;70:1018-1024.

273 Xing EP, Nie Y, Song Y, Yang GY, Cai YC, Wang LD, Yang CS: Mechanisms of inactivation of p14ARF, p15INK4b, and p16INK4a genes in human esophageal squamous cell carcinoma. Clin Cancer Res 1999;5:2704-2713.

274 Tsujimoto H, Hagiwara A, Sugihara H, Hattori T, Yamagishi H: Promoter methylations of p16INK4a and p14ARF genes in early and advanced gastric cancer. Correlations of the modes of their occurrence with histologic type. Pathology, research and practice 2002;198:785-794.

-275 Iida S, Akiyama Y, Nakajima T, Ichikawa W, Nihei Z, Sugihara K, Yuasa Y: Alterations and hypermethylation of the p14(ARF) gene in gastric cancer. Int J Cancer 2000;87:654-658.

276 Wu DL, Sui FY, Jiang XM, Jiang XH: Methylation in esophageal carcinogenesis. World J Gastroenterol 2006;12:6933-6940.

277 Tang S, Luo H, Yu J, Yang D, Shu J: Relationship between alterations of p16(INK4a) and p14(ARF) genes of CDKN2A locus and gastric carcinogenesis. Chinese medical journal 2003;116:1083-1087.

-278 Shigeishi H, Yokozaki H, Oue N, Kuniyasu H, Kondo T, Ishikawa T, Yasui W: Increased expression of CHK2 in human gastric carcinomas harboring p53 mutations. I Int J Cancer 2002;99:58-62.

279 Ishiyama A, Hibi K, Koike M, Fujiwara M, Kodera Y, Ito K, Nakao A: PTCH gene expression as a potential marker for esophageal squamous cell carcinoma. Anticancer Res 2006;26:195-198.

280 Yamashita K, Upadhyay S, Osada M, Hoque MO, Xiao Y, Mori M, Sato F, Meltzer SJ, Sidransky D: Pharmacologic unmasking of epigenetically silenced tumor suppressor genes in esophageal squamous cell carcinoma. Cancer cell 2002;2:485-495.

281 Sangodkar J, Shi J, DiFeo A, Schwartz R, Bromberg R, Choudhri A, McClinch K, Hatami R, Scheer E, Kremer-Tal S, Martignetti JA, Hui A, Leung WK, Friedman SL, Narla G: Functional role of the KLF6 tumour suppressor gene in gastric cancer. Eur J Cancer 2009;45:666-676. 


\section{Cellular Physiology Cell Physiol Biochem 2018;51:2647-2693 \begin{tabular}{l|l|l} 
and Biochemistry Published onlIne: 12 December 2018 & $\begin{array}{l}\text { ○ 2018 The Author(s). Published by S. Karger AG, Basel } \\
\text { www.karger.com/cpb }\end{array}$ \\
\hline
\end{tabular}}

Wang et al.: Loss of Tumor Suppressor Genes Function

282 Cho YG, Kim CJ, Park CH, Yang YM, Kim SY, Nam SW, Lee SH, Yoo NJ, Lee JY, Park WS: Genetic alterations of the KLF6 gene in gastric cancer. Oncogene 2005;24:4588-4590.

283 Dunn J, Garde J, Dolan K, Gosney JR, Sutton R, Meltzer SJ, Field JK: Multiple target sites of allelic imbalance on chromosome 17 in Barrett's oesophageal cancer. Oncogene 1999;18:987-993.

284 Uchida T, Matozaki T, Suzuki T, Matsuda K, Wada K, Nakano O, Konda Y, Nishisaki H, Nagao M, Sakamoto C, Kasuga M: Expression of two types of neurofibromatosis type 1 gene transcripts in gastric cancers and comparison of GAP activities. Biochem Bioph Res Co 1992;187:332-339.

285 Bektas N, Donner A, Wirtz C, Heep H, Gabbert HE, Sarbia M: Allelic loss involving the tumor suppressor genes APC and MCC and expression of the APC protein in the development of dysplasia and carcinoma in Barrett esophagus. Am J clin pathol 2000;114:890-895.

286 Owonikoko T, Loberg C, Gabbert HE, Sarbia M: Comparative analysis of basaloid and typical squamous cell carcinoma of the oesophagus: a molecular biological and immunohistochemical study. J Pathol 2001;193:155-161.

287 Miura JT, Xiu J, Thomas J, George B, Carron BR, Tsai S, Johnston FM, Turaga KK, Gamblin TC: Tumor profiling of gastric and esophageal carcinoma reveal different treatment options. Cancer Biol Ther 2015;16:764769.

288 Blount PL, Ramel S, Raskind WH, Haggitt RC, Sanchez CA, Dean PJ, Rabinovitch PS, Reid BJ: 17p allelic deletions and p53 protein overexpression in Barrett's adenocarcinoma. Cancer Res 1991;51:5482-5486.

289 Grace A, Butler D, Gallagher M, Al-Agha R, Xin Y, Leader M, Kay E: APC gene expression in gastric carcinoma: an immunohistochemical study. Appl Immunohisto Mol Morphol 2002;10:221-224.

290 Wu LB, Kushima R, Borchard F, Molsberger G, Hattori T: Intramucosal carcinomas of the stomach: phenotypic expression and loss of heterozygosity at microsatellites linked to the APC gene. Pathol Res Pract 1998;194:405-411.

291 Bataille F, Rummele P, Dietmaier W, Gaag D, Klebl F, Reichle A, Wild P, Hofstadter F, Hartmann A: Alterations in 553 predict response to preoperative high dose chemotherapy in patients with gastric cancer. Mol Pathol 2003;56:286-292.

-292 Ebert MP, Fei G, Kahmann S, Muller O, Yu J, Sung JJ, Malfertheiner P: Increased beta-catenin mRNA levels and mutational alterations of the APC and beta-catenin gene are present in intestinal-type gastric cancer. Carcinogenesis 2002;23:87-91.

293 Kim S, Lee J, Hong ME, Do IG, Kang SY, Ha SY, Kim ST, Park SH, Kang WK, Choi MG, Lee JH, Sohn TS, Bae JM, Kim S, Kim DH, Kim KM: High-throughput sequencing and copy number variation detection using formalin fixed embedded tissue in metastatic gastric cancer. PloS one 2014;9:e111693.

294 Park HL, Kim MS, Yamashita K, Westra W, Carvalho AL, Lee J, Jiang WW, Baek JH, Liu J, Osada M, Moon CS, Califano JA, Mori M, Sidransky D: DCC promoter hypermethylation in esophageal squamous cell carcinoma. Int J Cancer 2008;122:2498-2502.

295 Miyake S, Nagai K, Yoshino K, Oto M, Endo M, Yuasa Y: Point mutations and allelic deletion of tumor suppressor gene DCC in human esophageal squamous cell carcinomas and their relation to metastasis. Cancer Res 1994;54:3007-3010.

296 Sato K, Tamura G, Tsuchiya T, Endoh Y, Usuba O, Kimura W, Motoyama T: Frequent loss of expression without sequence mutations of the DCC gene in primary gastric cancer. British J Cancer 2001;85:199-203.

297 Fang DC, Jass JR, Wang DX: Loss of heterozygosity and loss of expression of the DCC gene in gastric cancer. J Clin Pathol 1998;51:593-596.

-298 Toda K, Nagasaka T, Umeda Y, Tanaka T, Kawai T, Fuji T, Taniguchi F, Yasui K, Kubota N, Takehara Y, Tazawa H, Kagawa S, Sun DS, Nishida N, Goel A, Fujiwara T: Genetic and epigenetic alterations of netrin-1 receptors in gastric cancer with chromosomal instability. Clin Epigenetics 2015;7:73.

299 Yang YX, Xue LY, Dong LJ, Fu M, Zhan QM, Tong T: [Expression and clinical significance of BRCA1 in human esophageal squamous cell carcinoma]. Zhonghua zhong liu za zhi [Chinese journal of oncology] 2012;34:905-909.

300 Beger C, Ramadani M, Meyer S, Leder G, Kruger M, Welte K, Gansauge F, Beger HG: Down-regulation of BRCA1 in chronic pancreatitis and sporadic pancreatic adenocarcinoma. Clin Cancer Res 2004;10:37803787. 


\section{Cellular Physiology Cell Physiol Biochem 2018;51:2647-2693 and Biochemistry Published \begin{tabular}{l|l} 
DOI: 10.1159/000495956 & $\begin{array}{l}\text { (c) } 2018 \text { The Author(s). Published by S. Karger AG, Basel } \\
\text { www.karger.com/cpb }\end{array}$
\end{tabular}}

Wang et al.: Loss of Tumor Suppressor Genes Function

301 Uehara H, Miyamoto M, Kato K, Cho Y, Kurokawa T, Murakami S, Fukunaga A, Ebihara Y, Kaneko H, Hashimoto H, Murakami Y, Shichinohe T, Kawarada Y, Itoh T, Okushiba S, Kondo S, Katoh H: Deficiency of hMLH1 and hMSH2 expression is a poor prognostic factor in esophageal squamous cell carcinoma. J Surg Oncol 2005;92:109-115.

-302 Ling ZQ, Zhao Q, Zhou SL, Mao WM: MSH2 promoter hypermethylation in circulating tumor DNA is a valuable predictor of disease-free survival for patients with esophageal squamous cell carcinoma. Eur J Surg Oncol 2012;38:326-332.

303 Kitajima Y, Miyazaki K, Matsukura S, Tanaka M, Sekiguchi M: Loss of expression of DNA repair enzymes MGMT, hMLH1, and hMSH2 during tumor progression in gastric cancer. Gastric cancer 2003;6:86-95.

304 Lee HJ, Jang YJ, Lee EJ, Kim JH, Park SS, Park SH, Kim CS, Mok YJ: The significance of mismatch repair genes in gastric cancer. J Cancer Res Ther 2013;9:80-83.

305 Wu MS, Sheu JC, Shun CT, Lee WJ, Wang JT, Wang TH, Cheng AL, Lin JT: Infrequent hMSH2 mutations in sporadic gastric adenocarcinoma with microsatellite instability. Cancer Lett 1997;112:161-166.

-306 Bevilacqua RA, Simpson AJ: Methylation of the hMLH1 promoter but no hMLH1 mutations in sporadic gastric carcinomas with high-level microsatellite instability. Int J Cancer 2000;87:200-203.

-307 Moura Lima E, Ferreira Leal M, Cardoso Smith Mde A, Rodriguez Burbano R, Pimentel de Assumpcao P, Bello MJ, Rey JA, Ferreira de Lima F, Casartelli C: DNA mismatch repair gene methylation in gastric cancer in individuals from northern Brazil. Biocell 2008;32:237-243.

308 Chang Z, Zhang W, Chang Z, Song M, Qin Y, Chang F, Guo H, Wei Q: Expression characteristics of FHIT, p53, BRCA2 and MLH1 in families with a history of oesophageal cancer in a region with a high incidence of oesophageal cancer. Oncol Lett 2015;9:430-436.

309 Wu D, Chen X, Xu Y, Wang H, Yu G, Jiang L, Hong Q Duan S: Prognostic value of MLH1 promoter methylation in male patients with esophageal squamous cell carcinoma. Oncol Lett 2017;13:2745-2750.

-310 Ding Y, Shimada Y, Kano M, Itami A, Kawabe A, Maeda M, Li Z, Hong T, Sato F, Kaganoi J, Imamura M: PTEN/ MMAC1 expression in esophageal squamous cell carcinomas. Int J Oncol 2000;17:695-699.

-311 Mikhail S, Ciombor K, Noonan A, Wu C, Goldberg R, Zhao W, Wei L, Mathey K, Yereb M, Timmers C, BekaiiSaab T: Upfront molecular testing in patients with advanced gastro-esophageal cancer: Is it time yet? Oncotarget 2015;6:22206-22213.

312 Hu YC, Lam KY, Tang JC, Srivastava G: Mutational analysis of the PTEN/MMAC1 gene in primary oesophageal squamous cell carcinomas. Mol Pathol 1999;52:353-356.

-313 Sun Z, Ji N, Bi M, Wang S, Liu X, Wang Z: PTEN gene is infrequently hypermethylated in human esophageal squamous cell carcinoma. Tumour Biol 2015;36:5849-5857.

314 Zheng H, Takahashi H, Murai Y, Cui Z, Nomoto K, Tsuneyama K, Takano Y: Low expression of FHIT and PTEN correlates with malignancy of gastric carcinomas: tissue-array findings. Appl Immunohisto Mol Morphol 2007;15:432-440.

315 Mina S, Bohn BA, Simon R, Krohn A, Reeh M, Arnold D, Bokemeyer C, Sauter G, Izbicki JR, Marx A, Stahl PR: PTEN deletion is rare but often homogeneous in gastric cancer. J Clin Pathol 2012;65:693-698.

-316 Wen YG, Wang Q, Zhou CZ, Qiu GQ, Peng ZH, Tang HM: Mutation analysis of tumor suppressor gene PTEN in patients with gastric carcinomas and its impact on PI3K/AKT pathway. Oncol Rep 2010;24:89-95.

317 Kang YH, Lee HS, Kim WH: Promoter methylation and silencing of PTEN in gastric carcinoma. Lab Invest 2002;82:285-291.

318 Jiang S, Chen R, Yu J, Li N, Ke R, Luo L, Zou J, Zhang J, Zhang K, Lu N, Huang D: Clinical significance and role of LKB1 in gastric cancer. Mol Med Rep 2016;13:249-256.

-319 Ling ZQ, Li P, Ge MH, Zhao X, Hu FJ, Fang XH, Dong ZM, Mao WM: Hypermethylation-modulated downregulation of CDH1 expression contributes to the progression of esophageal cancer. Int J Mol Med 2011;27:625-635.

320 Fukai Y, Fukuchi M, Masuda N, Osawa H, Kato H, Nakajima T, Kuwano H: Reduced expression of transforming growth factor-beta receptors is an unfavorable prognostic factor in human esophageal squamous cell carcinoma. Int J Cancer 2003;104:161-166.

-321 Souza RF, Garrigue-Antar L, Lei J, Yin J, Appel R, Vellucci VF, Zou TT, Zhou X, Wang S, Rhyu MG, Cymes K, Chan O, Park WS, Krasna MJ, Greenwald BD, Cottrell J, Abraham JM, Simms L, Leggett B, Young J, Harpaz N, Reiss M, Meltzer SJ: Alterations of transforming growth factor-beta 1 receptor type II occur in ulcerative colitis-associated carcinomas, sporadic colorectal neoplasms, and esophageal carcinomas, but not in gastric neoplasms. Hum Cell 1996;9:229-236. 


\section{Cellular Physiology Cell Physiol Biochem 2018;51:2647-2693 \begin{tabular}{l|l|l} 
and Biochemistry Published onlIne: 12 December 2018 & $\begin{array}{l}\text { ○ } 2018 \text { The Author(s). Published by S. Karger AG, Basel } \\
\text { www.karger.com/cpb }\end{array}$ \\
\hline
\end{tabular}}

Wang et al.: Loss of Tumor Suppressor Genes Function

-322 Ito M, Yasui W, Nakayama H, Yokozaki H, Ito H, Tahara E: Reduced levels of transforming growth factor-beta type I receptor in human gastric carcinomas. Jpn J Cancer Res : Gann 1992;83:86-92.

-323 Kang SH, Bang YJ, Im YH, Yang HK, Lee DA, Lee HY, Lee HS, Kim NK, Kim SJ: Transcriptional repression of the transforming growth factor-beta type I receptor gene by DNA methylation results in the development of TGF-beta resistance in human gastric cancer. Oncogene 1999;18:7280-7286.

-324 Pinto M, Oliveira C, Cirnes L, Carlos Machado J, Ramires M, Nogueira A, Carneiro F, Seruca R: Promoter methylation of TGFbeta receptor I and mutation of TGFbeta receptor II are frequent events in MSI sporadic gastric carcinomas. J Pathol 2003;200:32-38.

-325 Takeno S, Wirtz HC, Lickvers K, Noguchi T, Scheven M, Willers R, Gabbert HE, Mueller W: Transforming growth factor beta type II receptor expression in gastric cancer: evidence for two independent subgroups. Anticancer Res 2002;22:2247-2252.

-326 Guo RJ, Wang Y, Kaneko E, Wang DY, Arai H, Hanai H, Takenoshita S, Hagiwara K, Harris CC, Sugimura H: Analyses of mutation and loss of heterozygosity of coding sequences of the entire transforming growth factor beta type II receptor gene in sporadic human gastric cancer. Carcinogenesis 1998;19:1539-1544.

327 Natsugoe S, Xiangming C, Matsumoto M, Okumura H, Nakashima S, Sakita H, Ishigami S, Baba M, Takao S, Aikou T: Smad4 and transforming growth factor beta1 expression in patients with squamous cell carcinoma of the esophagus. Clin Cancer Res 2002;8:1838-1842.

328 Barrett MT, Schutte M, Kern SE, Reid BJ: Allelic loss and mutational analysis of the DPC4 gene in esophageal adenocarcinoma. Cancer Res 1996;56:4351-4353.

-329 Onwuegbusi BA, Aitchison A, Chin SF, Kranjac T, Mills I, Huang Y, Lao-Sirieix P, Caldas C, Fitzgerald RC: Impaired transforming growth factor beta signalling in Barrett's carcinogenesis due to frequent SMAD4 inactivation. Gut 2006;55:764-774.

-330 Kloth JN, Kenter GG, Spijker HS, Uljee S, Corver WE, Jordanova ES, Fleuren GJ, Gorter A: Expression of Smad2 and Smad4 in cervical cancer: absent nuclear Smad4 expression correlates with poor survival. Modern Pathol 2008;21:866-875.

331 Maesawa C, Tamura G, Nishizuka S, Iwaya T, Ogasawara S, Ishida K, Sakata K, Sato N, Ikeda K, Kimura Y, Saito K, Satodate R: MAD-related genes on 18q21.1, Smad2 and Smad4, are altered infrequently in esophageal squamous cell carcinoma. Jpn J Cancer Res: Gann 1997;88:340-343.

-332 Pizzi S, Azzoni C, Bassi D, Bottarelli L, Milione M, Bordi C: Genetic alterations in poorly differentiated endocrine carcinomas of the gastrointestinal tract. Cancer 2003;98:1273-1282.

333 Shitara Y, Yokozaki H, Yasui W, Takenoshita S, Kuwano H, Nagamachi Y, Tahara E: No mutations of the Smad2 gene in human sporadic gastric carcinomas. Jpn J Clinic Oncol 1999;29:3-7.

334 Iacopetta B: TP53 mutation in colorectal cancer. Hum Mutat 2003;21:271-276.

-335 Baker SJ, Fearon ER, Nigro JM, Hamilton SR, Preisinger AC, Jessup JM, vanTuinen P, Ledbetter DH, Barker DF, Nakamura Y, White R, Vogelstein B: Chromosome 17 deletions and p53 gene mutations in colorectal carcinomas. Science 1989;244:217-221.

336 Cunningham J, Lust JA, Schaid DJ, Bren GD, Carpenter HA, Rizza E, Kovach JS, Thibodeau SN: Expression of p53 and 17p allelic loss in colorectal carcinoma. Cancer Res 1992;52:1974-1980.

-337 Lothe RA, Fossli T, Danielsen HE, Stenwig AE, Nesland JM, Gallie B, Borresen AL: Molecular genetic studies of tumor suppressor gene regions on chromosomes 13 and 17 in colorectal tumors. Journal of the National Cancer Institute 1992;84:1100-1108.

338 Chang SC, Lin JK, Lin TC, Liang WY: Loss of heterozygosity: an independent prognostic factor of colorectal cancer. World J Gastroenterol 2005;11:778-784.

-339 Kasuya K, Watanabe H, Nakasako T, Ajioka Y, Koyanagi Y: p53 protein overexpression and K-ras codon 12 mutation in pancreatic ductal carcinoma: correlation with histologic factors. Pathology international 1997;47:531-539.

340 Pantalone D, Pelo E, Minuti B, Giotti I, Mazza E, Falchini M, Neri B, Nesi G, Roberta Girardi L, Pulli R, Credi G, Torricelli F: p53 and DPC4 alterations in the bile of patients with pancreatic carcinoma. J Surg Oncol 2004;88:210-216.

-341 Luttges J, Galehdari H, Brocker V, Schwarte-Waldhoff I, Henne-Bruns D, Kloppel G, Schmiegel W, Hahn SA: Allelic loss is often the first hit in the biallelic inactivation of the p53 and DPC4 genes during pancreatic carcinogenesis. Am J Pathol 2001;158:1677-1683. 


\section{Cellular Physiology Cell Physiol Biochem 2018;51:2647-2693 \begin{tabular}{ll|l} 
and Biochemistry Published onlIne: 12 December 2018 & $\begin{array}{l}\text { (c) } 2018 \text { The Author(s). Published by S. Karger AG, Basel } \\
\text { www.karger.com/cpb }\end{array}$ \\
\hline
\end{tabular}}

Wang et al.: Loss of Tumor Suppressor Genes Function

342 Nakamori S, Yashima K, Murakami Y, Ishikawa O, Ohigashi H, Imaoka S, Yaegashi S, Konishi Y, Sekiya T: Association of p53 gene mutations with short survival in pancreatic adenocarcinoma. Jpn J Cancer Res Gann 1995;86:174-181.

-343 Ali AA, Marcus JN, Harvey JP, Roll R, Hodgson CP, Wildrick DM, Chakraborty A, Boman BM: RB1 protein in normal and malignant human colorectal tissue and colon cancer cell lines. FASEB journal 1993;7:931-937.

-344 Cawkwell L, Lewis FA, Quirke P: Frequency of allele loss of DCC, p53, RBI, WT1, NF1, NM23 and APC/ MCC in colorectal cancer assayed by fluorescent multiplex polymerase chain reaction. British J Cancer 1994;70:813-818.

345 Huang L, Lang D, Geradts J, Obara T, Klein-Szanto AJ, Lynch HT, Ruggeri BA: Molecular and immunochemical analyses of RB1 and cyclin D1 in human ductal pancreatic carcinomas and cell lines. Mol Carcinogen 1996;15:85-95.

346 Barton CM, McKie AB, Hogg A, Bia B, Elia G, Phillips SM, Ding SF, Lemoine NR: Abnormalities of the RB1 and DCC tumor suppressor genes: uncommon in human pancreatic adenocarcinoma. Mol Carcinogen 1995;13:61-69.

-347 Nemtsova MN, Pal'tseva EM, Babaian A, Mikhailenko DS, Babenko OV, Samofalova O, Tsar'kov PV, Zaletaev DV: [Molecular-genetic analysis of clonal intratumoral heterogeneity on colorectal adenocarcinomas]. Molekuliarnaia biologiia 2008;42:1040-1047.

348 Sherr CJ: The INK4a/ARF network in tumour suppression. Nat Rev Mol Cell Biol 2001;2:731-737.

-349 Esteller M, Tortola S, Toyota M, Capella G, Peinado MA, Baylin SB, Herman JG: Hypermethylation-associated inactivation of $\mathrm{p} 14(\mathrm{ARF})$ is independent of p16(INK4a) methylation and p53 mutational status. Cancer Res 2000;60:129-133.

-350 Bai AH, Tong JH, To KF, Chan MW, Man EP, Lo KW, Lee JF, Sung JJ, Leung WK: Promoter hypermethylation of tumor-related genes in the progression of colorectal neoplasia. Int J Cancer 2004;112:846-853.

351 Xu XL, Yu J, Zhang HY, Sun MH, Gu J, Du X, Shi DR, Wang P, Yang ZH, Zhu JD: Methylation profile of the promoter $\mathrm{CpG}$ islands of 31 genes that may contribute to colorectal carcinogenesis. World J Gastroenterol 2004;10:3441-3454.

-352 Geradts J, Wilentz RE, Roberts H: Immunohistochemical [corrected] detection of the alternate INK4aencoded tumor suppressor protein p14(ARF) in archival human cancers and cell lines using commercial antibodies: correlation with p16(INK4a) expression. Modern Pathol 2001;14:1162-1168.

-353 Ghiorzo P, Pastorino L, Bonelli L, Cusano R, Nicora A, Zupo S, Queirolo P, Sertoli M, Pugliese V, BianchiScarra G: INK4/ARF germline alterations in pancreatic cancer patients. Ann Oncol 2004;15:70-78.

354 House MG, Guo M, Iacobuzio-Donahue C, Herman JG: Molecular progression of promoter methylation in intraductal papillary mucinous neoplasms (IPMN) of the pancreas. Carcinogenesis 2003;24:193-198.

355 House MG, Herman JG, Guo MZ, Hooker CM, Schulick RD, Lillemoe KD, Cameron JL, Hruban RH, Maitra A, Yeo CJ: Aberrant hypermethylation of tumor suppressor genes in pancreatic endocrine neoplasms. Ann Surg 2003;238:423-431; discussion 431-422.

-356 Stawinska M, Cygankiewicz A, Trzcinski R, Mik M, Dziki A, Krajewska WM: Alterations of Chk1 and Chk2 expression in colon cancer. Int J Colorectal Dis 2008;23:1243-1249.

-357 Liu WD, Zhong BY, Zhang YD, Choi GS: Mutation analysis of the checkpoint kinase 2 gene in colorectal cancer cell lines. Chinese Medical Journal 2007;120:2119-2123.

358 Williams LH, Choong D, Johnson SA, Campbell IG: Genetic and epigenetic analysis of CHEK2 in sporadic breast, colon, and ovarian cancers. Clin Cancer Res 2006;12:6967-6972.

359 Duong HQ Hong YB, Kim JS, Lee HS, Yi YW, Kim YJ, Wang A, Zhao W, Cho CH, Seong YS, Bae I: Inhibition of checkpoint kinase 2 (CHK2) enhances sensitivity of pancreatic adenocarcinoma cells to gemcitabine. J Cell Mol Med 2013;17:1261-1270.

360 Cho YG, Choi BJ, Song JW, Kim SY, Nam SW, Lee SH, Yoo NJ, Lee JY, Park WS: Aberrant expression of krUppellike factor 6 protein in colorectal cancers. World J Gastroenterol 2006;12:2250-2253.

-361 Reeves HL, Narla G, Ogunbiyi O, Haq AI, Katz A, Benzeno S, Hod E, Harpaz N, Goldberg S, Tal-Kremer S, Eng FJ, Arthur MJ, Martignetti JA, Friedman SL: Kruppel-like factor 6 (KLF6) is a tumor-suppressor gene frequently inactivated in colorectal cancer. Gastroenterology 2004;126:1090-1103.

-362 Wahab AH, Kassem AM, Matter S, El Deen AF, Helmy AS, Ismaeil MM, Zakaria MS: Role of KLF6 tumor suppressor gene mutations in the development of colorectal carcinoma in an Egyptian population. Hepatogastroenterology 2010;57:1405-1410. 


\section{Cellular Physiology Cell Physiol Biochem 2018;51:2647-2693 \begin{tabular}{ll|l} 
and Biochemistry & $\begin{array}{l}\text { DOI: 10.1159/000495956 } \\
\text { Published onlIne: 12 December } 2018\end{array}$ & $\begin{array}{l}\text { (c) } 2018 \text { The Author(s). Published by S. Karger AG, Basel } \\
\text { www.karger.com/cpb }\end{array}$
\end{tabular}}

Wang et al.: Loss of Tumor Suppressor Genes Function

-363 Lievre A, Landi B, Cote JF, Veyrie N, Zucman-Rossi J, Berger A, Laurent-Puig P: Absence of mutation in the putative tumor-suppressor gene KLF6 in colorectal cancers. Oncogene 2005;24:7253-7256.

364 Hartel M, Narla G, Wente MN, Giese NA, Martignoni ME, Martignetti JA, Friess H, Friedman SL: Increased alternative splicing of the KLF6 tumour suppressor gene correlates with prognosis and tumour grade in patients with pancreatic cancer. Eur J Cancer 2008;44:1895-1903.

365 Cacev T, Radosevic S, Spaventi R, Pavelic K, Kapitanovic S: NF1 gene loss of heterozygosity and expression analysis in sporadic colon cancer. Gut 2005;54:1129-1135.

-366 Yap YS, McPherson JR, Ong CK, Rozen SG, Teh BT, Lee AS, Callen DF: The NF1 gene revisited - from bench to bedside. Oncotarget 2014;5:5873-5892.

-367 Li Y, Bollag G, Clark R, Stevens J, Conroy L, Fults D, Ward K, Friedman E, Samowitz W, Robertson M, Bradley P, McCormick F, White R, Cawthon R: Somatic mutations in the neurofibromatosis 1 gene in human tumors. Cell 1992;69:275-281.

-368 Dai WB, Ren ZP, Chen WL, Du J, Shi Z, Tang DY: [Expression and significance of APC, beta-catenin, C-myc, and Cyclin D1 proteins in colorectal carcinoma]. Ai zheng = Aizheng = Chinese J Cancer 2007;26:963-966.

-369 Chen J, Rocken C, Lofton-Day C, Schulz HU, Muller O, Kutzner N, Malfertheiner P, Ebert MP: Molecular analysis of APC promoter methylation and protein expression in colorectal cancer metastasis. Carcinogenesis 2005;26:37-43.

-370 Kapitanovic S, Cacev T, Radosevic S, Spaventi S, Spaventi R, Pavelic K: APC gene loss of heterozygosity, mutations, E1317Q, and I1307K germ-line variants in sporadic colon cancer in Croatia. Exp Mol Pathol 2004;77:193-200.

-371 Rowan AJ, Lamlum H, Ilyas M, Wheeler J, Straub J, Papadopoulou A, Bicknell D, Bodmer WF, Tomlinson IP: APC mutations in sporadic colorectal tumors: A mutational "hotspot" and interdependence of the "two hits". Proc Natl Acad Sci U S A 2000;97:3352-3357.

-372 Hasanpour M, Galehdari H, Masjedizadeh A, Ajami N: A unique profile of adenomatous polyposis coli gene mutations in Iranian patients suffering sporadic colorectal cancer. Cell J 2014;16:17-24.

-373 Arnold CN, Goel A, Niedzwiecki D, Dowell JM, Wasserman L, Compton C, Mayer RJ, Bertagnolli MM, Boland CR: APC promoter hypermethylation contributes to the loss of APC expression in colorectal cancers with allelic loss on 5q. Cancer Biol Ther 2004;3:960-964.

-374 Chetty R, Serra S, Salahshor S, Alsaad K, Shih W, Blaszyk H, Woodgett JR, Tsao MS: Expression of Wntsignaling pathway proteins in intraductal papillary mucinous neoplasms of the pancreas: a tissue microarray analysis. Hum Pathol 2006;37:212-217.

375 Horii A, Nakatsuru S, Miyoshi Y, Ichii S, Nagase H, Ando H, Yanagisawa A, Tsuchiya E, Kato Y, Nakamura Y: Frequent somatic mutations of the APC gene in human pancreatic cancer. Cancer Res 1992;52:6696-6698.

376 Seymour AB, Hruban RH, Redston M, Caldas C, Powell SM, Kinzler KW, Yeo CJ, Kern SE: Allelotype of pancreatic adenocarcinoma. Cancer Res 1994;54:2761-2764.

377 Kataoka M, Okabayashi T, Orita K: Decreased expression of DCC mRNA in gastric and colorectal cancer. Surg Today 1995;25:1001-1007.

-378 Fearon ER, Cho KR, Nigro JM, Kern SE, Simons JW, Ruppert JM, Hamilton SR, Preisinger AC, Thomas G, Kinzler KW, Vogelstein B: Identification of a chromosome 18q gene that is altered in colorectal cancers. Science 1990;247:49-56.

-379 Ashktorab H, Brim H: DNA Methylation and Colorectal Cancer. Curr Colorectal Cancer Rep 2014;10:425430.

-380 Hohne MW, Halatsch ME, Kahl GF, Weinel RJ: Frequent loss of expression of the potential tumor suppressor gene DCC in ductal pancreatic adenocarcinoma. Cancer Res 1992;52:2616-2619.

-381 Tarafa G, Villanueva A, Farre L, Rodriguez J, Musulen E, Reyes G, Seminago R, Olmedo E, Paules AB, Peinado MA, Bachs 0, Capella G: DCC and SMAD4 alterations in human colorectal and pancreatic tumor dissemination. Oncogene 2000;19:546-555.

382 Xu Z, Zhang L: BRCA1 expression serves a role in vincristine resistance in colon cancer cells. Oncol Lett 2017;14:345-348.

383 Garcia JM, Rodriguez R, Dominguez G, Silva JM, Provencio M, Silva J, Colmenarejo A, Millan I, Munoz C, Salas C, Coca S, Espana P, Bonilla F: Prognostic significance of the allelic loss of the BRCA1 gene in colorectal cancer. Gut 2003;52:1756-1763.

384 Sopik V, Phelan C, Cybulski C, Narod SA: BRCA1 and BRCA2 mutations and the risk for colorectal cancer. Clin Genet 2015;87:411-418. 


\section{Cellular Physiology Cell Physiol Biochem 2018;51:2647-2693 \begin{tabular}{l|l|l} 
and Biochemistry Published online: 12 December 2018 & $\begin{array}{l}\text { (c) } 2018 \text { The Author(s). Published by S. Karger AG, Basel } \\
\text { www.karger.com/cpb }\end{array}$ \\
\hline
\end{tabular}}

Wang et al.: Loss of Tumor Suppressor Genes Function

385 Dagan E: Predominant Ashkenazi BRCA1/2 mutations in families with pancreatic cancer. Genet Test 2008;12:267-271.

386 Perrin J, Gouvernet J, Parriaux D, Noguchi T, Giovannini MH, Giovannini M, Delpero JR, Birnbaum D, Monges G: MSH2 and MLH1 immunodetection and the prognosis of colon cancer. Int J Oncol 2001;19:891-895.

387 Malhotra P, Anwar M, Kochhar R, Ahmad S, Vaiphei K, Mahmood S: Promoter methylation and immunohistochemical expression of hMLH1 and hMSH2 in sporadic colorectal cancer: a study from India. Tumour Biol 2014;35:3679-3687.

-388 Gille JJ, Hogervorst FB, Pals G, Wijnen JT, van Schooten RJ, Dommering CJ, Meijer GA, Craanen ME, Nederlof PM, de Jong D, McElgunn CJ, Schouten JP, Menko FH: Genomic deletions of MSH2 and MLH1 in colorectal cancer families detected by a novel mutation detection approach. British J Cancer 2002;87:892-897.

389 Jacob S, Praz F: DNA mismatch repair defects: role in colorectal carcinogenesis. Biochimie 2002;84:27-47.

390 Kamory E, Kolacsek O, Otto S, Csuka O: hMLH1 and hMSH2 somatic inactivation mechanisms in sporadic colorectal cancer patients. Pathol Oncol Res 2003;9:236-241.

-391 Kondo E, Furukawa T, Yoshinaga K, Kijima H, Semba S, Yatsuoka T, Yokoyama T, Fukushige S, Horii A: Not hMSH2 but hMLH1 is frequently silenced by hypermethylation in endometrial cancer but rarely silenced in pancreatic cancer with microsatellite instability. Int J Oncol 2000;17:535-541.

-392 Ghimenti C, Tannergard P, Wahlberg S, Liu T, Giulianotti PG, Mosca F, Fornaciari G, Bevilacqua G, Lindblom A, Caligo MA: Microsatellite instability and mismatch repair gene inactivation in sporadic pancreatic and colon tumours. British J Cancer 1999;80:11-16.

393 Ueki T, Toyota M, Sohn T, Yeo CJ, Issa JP, Hruban RH, Goggins M: Hypermethylation of multiple genes in pancreatic adenocarcinoma. Cancer Res 2000;60:1835-1839.

\$394 Goel A, Arnold CN, Niedzwiecki D, Carethers JM, Dowell JM, Wasserman L, Compton C, Mayer RJ, Bertagnolli MM, Boland CR: Frequent inactivation of PTEN by promoter hypermethylation in microsatellite instabilityhigh sporadic colorectal cancers. Cancer Res 2004;64:3014-3021.

-395 Lin PC, Lin JK, Lin HH, Lan YT, Lin CC, Yang SH, Chen WS, Liang WY, Jiang JK, Chang SC: A comprehensive analysis of phosphatase and tensin homolog deleted on chromosome 10 (PTEN) loss in colorectal cancer. World J Surg Oncol 2015;13:186.

-396 Asano T, Yao Y, Zhu J, Li D, Abbruzzese JL, Reddy SA: The PI 3-kinase/Akt signaling pathway is activated due to aberrant Pten expression and targets transcription factors NF-kappaB and c-Myc in pancreatic cancer cells. Oncogene 2004;23:8571-8580.

-397 Missiaglia E, Dalai I, Barbi S, Beghelli S, Falconi M, della Peruta M, Piemonti L, Capurso G, Di Florio A, delle Fave G, Pederzoli P, Croce CM, Scarpa A: Pancreatic endocrine tumors: expression profiling evidences a role for AKT-mTOR pathway. J Clinical Oncol 2010;28:245-255.

398 Eng C: PTEN: one gene, many syndromes. Hum Mutat 2003;22:183-198.

-399 Dong SM, Kim KM, Kim SY, Shin MS, Na EY, Lee SH, Park WS, Yoo NJ, Jang JJ, Yoon CY, Kim JW, Kim SY, Yang YM, Kim SH, Kim CS, Lee JY: Frequent somatic mutations in serine/threonine kinase 11/Peutz-Jeghers syndrome gene in left-sided colon cancer. Cancer Res 1998;58:3787-3790.

-400 Trojan J, Brieger A, Raedle J, Esteller M, Zeuzem S: 5'-CpG island methylation of the LKB1/STK11 promoter and allelic loss at chromosome 19p13.3 in sporadic colorectal cancer. Gut 2000;47:272-276.

-401 Sahin F, Maitra A, Argani P, Sato N, Maehara N, Montgomery E, Goggins M, Hruban RH, Su GH: Loss of Stk11/Lkb1 expression in pancreatic and biliary neoplasms. Modern Pathol 2003;16:686-691.

-402 Su GH, Hruban RH, Bansal RK, Bova GS, Tang DJ, Shekher MC, Westerman AM, Entius MM, Goggins M, Yeo CJ, Kern SE: Germline and somatic mutations of the STK11/LKB1 Peutz-Jeghers gene in pancreatic and biliary cancers. Am J Pathol 1999;154:1835-1840.

-403 Almeida FG, de Aquino PF, de Souza AD, de Souza AQ, do Carmo Vinhote S, Mac-Cormick TM, da Mota Silva MS, Chalub SR, de Saldanha da Gama Fischer J, Carvalho PC, da Gloria da Costa Carvalho M: Colorectal cancer DNA methylation patterns from patients in Manaus, Brazil. Biol Res 2015;48:50.

404 Shin SJ, Kim KO, Kim MK, Lee KH, Hyun MS, Kim KJ, Choi JH, Song HS: Expression of E-cadherin and uPA and their association with the prognosis of pancreatic cancer. Jpn J Clin Oncol 2005;35:342-348.

-405 Dansranjavin T, Mobius C, Tannapfel A, Bartels M, Wittekind C, Hauss J, Witzigmann H: E-cadherin and DAP kinase in pancreatic adenocarcinoma and corresponding lymph node metastases. Oncol Rep 2006;15:1125-1131. 


\section{Cellular Physiology Cell Physiol Biochem 2018;51:2647-2693

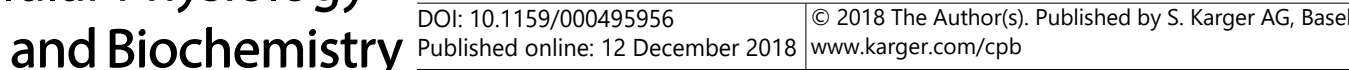

Wang et al.: Loss of Tumor Suppressor Genes Function

406 Matsushita M, Matsuzaki K, Date M, Watanabe T, Shibano K, Nakagawa T, Yanagitani S, Amoh Y, Takemoto H, Ogata N, Yamamoto C, Kubota Y, Seki T, Inokuchi H, Nishizawa M, Takada H, Sawamura T, Okamura A, Inoue K: Down-regulation of TGF-beta receptors in human colorectal cancer: implications for cancer development. British J Cancer 1999;80:194-205.

-407 Jonson T, Albrechtsson E, Axelson J, Heidenblad M, Gorunova L, Johansson B, Hoglund M: Altered expression of TGFB receptors and mitogenic effects of TGFB in pancreatic carcinomas. Int J Oncol 2001;19:71-81.

408 Goggins M, Shekher M, Turnacioglu K, Yeo CJ, Hruban RH, Kern SE: Genetic alterations of the transforming growth factor beta receptor genes in pancreatic and biliary adenocarcinomas. Cancer Res 1998;58:53295332.

409 Nagayama S, Onodera H, Toguchida J, Imamura M: Altered expression of the receptor and ligand in the TGF beta signaling pathway in diffusely infiltrating colon carcinoma. Anticancer Res 2002;22:3545-3554.

410 Biswas S, Chytil A, Washington K, Romero-Gallo J, Gorska AE, Wirth PS, Gautam S, Moses HL, Grady WM: Transforming growth factor beta receptor type II inactivation promotes the establishment and progression of colon cancer. Cancer Res 2004;64:4687-4692.

411 Miyaki M, Iijima T, Konishi M, Sakai K, Ishii A, Yasuno M, Hishima T, Koike M, Shitara N, Iwama T, Utsunomiya J, Kuroki T, Mori T: Higher frequency of Smad4 gene mutation in human colorectal cancer with distant metastasis. Oncogene 1999;18:3098-3103.

-412 Takagi Y, Kohmura H, Futamura M, Kida H, Tanemura H, Shimokawa K, Saji S: Somatic alterations of the DPC4 gene in human colorectal cancers in vivo. Gastroenterology 1996;111:1369-1372.

413 Roth S, Laiho P, Salovaara R, Launonen V, Aaltonen LA: No SMAD4 hypermethylation in colorectal cancer. British J Cancer 2000;83:1015-1019.

414 Tascilar M, Skinner HG, Rosty C, Sohn T, Wilentz RE, Offerhaus GJ, Adsay V, Abrams RA, Cameron JL, Kern SE, Yeo CJ, Hruban RH, Goggins M: The SMAD4 protein and prognosis of pancreatic ductal adenocarcinoma. Clin Cancer Resh 2001;7:4115-4121.

415 Hahn SA, Schutte M, Hoque AT, Moskaluk CA, da Costa LT, Rozenblum E, Weinstein CL, Fischer A, Yeo CJ, Hruban RH, Kern SE: DPC4, a candidate tumor suppressor gene at human chromosome 18q21.1 Science 1996;271:350-353.

416 Xie W, Rimm DL, Lin Y, Shih WJ, Reiss M: Loss of Smad signaling in human colorectal cancer is associated with advanced disease and poor prognosis. Cancer J 2003;9:302-312.

417 Ohtaki N, Yamaguchi A, Goi T, Fukaya T, Takeuchi K, Katayama K, Hirose K, Urano T: Somatic alterations of the DPC4 and Madr2 genes in colorectal cancers and relationship to metastasis. Int J Oncol 2001;18:265270.

-418 Kleeff J, Friess H, Simon P, Susmallian S, Buchler P, Zimmermann A, Buchler MW, Korc M: Overexpression of Smad2 and colocalization with TGF-beta1 in human pancreatic cancer. Digestive diseases and sciences 1999;44:1793-1802.

419 Kang YK, Kim CJ, Kim WH, Kim HO, Kang GH, Kim YI: p53 mutation and overexpression in hepatocellular carcinoma and dysplastic nodules in the liver. Virchows Archiv 1998;432:27-32.

420 Rashid A, Wang JS, Qian GS, Lu BX, Hamilton SR, Groopman JD: Genetic alterations in hepatocellular carcinomas: association between loss of chromosome 4q and p53 gene mutations. British J Cancer 1999;80:59-66.

421 Walker GJ, Hayward NK, Falvey S, Cooksley WG: Loss of somatic heterozygosity in hepatocellular carcinoma. Cancer Res 1991;51:4367-4370.

-422 Murakami Y, Hayashi K, Hirohashi S, Sekiya T: Aberrations of the tumor suppressor p53 and retinoblastoma genes in human hepatocellular carcinomas. Cancer Res 1991;51:5520-5525.

423 Rebbani K, Marchio A, Ezzikouri S, Afifi R, Kandil M, Bahri O, Triki H, El Feydi AE, Dejean A, Benjelloun S, Pineau P: TP53 R72P polymorphism modulates DNA methylation in hepatocellular carcinoma. Mol Cancer 2015;14:74.

424 Edamoto Y, Hara A, Biernat W, Terracciano L, Cathomas G, Riehle HM, Matsuda M, Fujii H, Scoazec JY, Ohgaki $\mathrm{H}$ : Alterations of RB1, p53 and Wnt pathways in hepatocellular carcinomas associated with hepatitis C, hepatitis B and alcoholic liver cirrhosis. Int J Cancer 2003;106:334-341.

425 Bernardini S, Adessi GL, Billerey C, Chezy E, Carbillet JP, Bittard H: Immunohistochemical detection of p53 protein overexpression versus gene sequencing in urinary bladder carcinomas. J Urol 1999;162:14961501. 


\section{Cellular Physiology Cell Physiol Biochem 2018;51:2647-2693 and Biochemistry Published \begin{tabular}{l|l} 
DOI: 10.1159/000495956 & $\begin{array}{l}\text { @ } 2018 \text { The Author(s). Published by S. Karger AG, Basel } \\
\text { www.karger.com/cpb }\end{array}$
\end{tabular}}

Wang et al.: Loss of Tumor Suppressor Genes Function

426 Oka K, Ishikawa J, Bruner JM, Takahashi R, Saya H: Detection of loss of heterozygosity in the p53 gene in renal cell carcinoma and bladder cancer using the polymerase chain reaction. Mol Carcinogen 1991;4:1013.

-427 Sidransky D, Von Eschenbach A, Tsai YC, Jones P, Summerhayes I, Marshall F, Paul M, Green P, Hamilton SR, Frost P, Vogelstein B: Identification of p53 gene mutations in bladder cancers and urine samples. Science 1991;252:706-709.

428 Olivier M, Eeles R, Hollstein M, Khan MA, Harris CC, Hainaut P: The IARC TP53 database: new online mutation analysis and recommendations to users. Hum Mutat 2002;19:607-614.

-429 Zhang X, Xu HJ, Murakami Y, Sachse R, Yashima K, Hirohashi S, Hu SX, Benedict WF, Sekiya T: Deletions of chromosome 13q, mutations in Retinoblastoma 1, and retinoblastoma protein state in human hepatocellular carcinoma. Cancer Res 1994;54:4177-4182.

430 Ashida K, Kishimoto Y, Nakamoto K, Wada K, Shiota G, Hirooka Y, Kamisaki Y, Itoh T, Kawasaki H: Loss of heterozygosity of the retinoblastoma gene in liver cirrhosis accompanying hepatocellular carcinoma. J Cancer Res Clin Oncol 1997;123:489-495.

431 Yu J, Ni M, Xu J, Zhang H, Gao B, Gu J, Chen J, Zhang L, Wu M, Zhen S, Zhu J: Methylation profiling of twenty promoter-CpG islands of genes which may contribute to hepatocellular carcinogenesis. BMC Cancer 2002;2:29.

432 Sourvinos G, Kazanis I, Delakas D, Cranidis A, Spandidos DA: Genetic detection of bladder cancer by microsatellite analysis of p16, RB1 and p53 tumor suppressor genes. The J Urol 2001;165:249-252.

433 Gallucci M, Guadagni F, Marzano R, Leonardo C, Merola R, Sentinelli S, Ruggeri EM, Cantiani R, Sperduti I, Lopez Fde L, Cianciulli AM: Status of the p53, p16, RB1, and HER-2 genes and chromosomes 3, 7, 9, and 17 in advanced bladder cancer: correlation with adjacent mucosa and pathological parameters. J Clin Pathol 2005;58:367-371.

434 Miyamoto H, Shuin T, Torigoe S, Iwasaki Y, Kubota Y: Retinoblastoma gene mutations in primary human bladder cancer. British J Cancer 1995;71:831-835.

435 Malekzadeh K, Sobti RC, Nikbakht M, Shekari M, Hosseini SA, Tamandani DK, Singh SK: Methylation patterns of Rb1 and Casp-8 promoters and their impact on their expression in bladder cancer. Cancer Invest 2009;27:70-80.

436 Huang J, Shen W, Li B, Luo Y, Liao S, Zhang W, Cheng N: Molecular and immunohistochemical study of the inactivation of the p16 gene in primary hepatocellular carcinoma. Chinese medical journal 2000;113:889893.

437 Peng CY, Chen TC, Hung SP, Chen MF, Yeh CT, Tsai SL, Chu CM, Liaw YF: Genetic alterations of INK4alpha/ ARF locus and p53 in human hepatocellular carcinoma. Anticancer Res 2002;22:1265-1271.

438 Tannapfel A, Busse C, Weinans L, Benicke M, Katalinic A, Geissler F, Hauss J, Wittekind C: INK4a-ARF alterations and p53 mutations in hepatocellular carcinomas. Oncogene 2001;20:7104-7109.

439 Raspollini MR, Nesi G, Baroni G, Girardi LR, Taddei GL: p16(INK4a) expression in urinary bladder carcinoma. Archivio italiano di urologia, andrologia : organo ufficiale [di] Societa italiana di ecografia urologica e nefrologica 2006;78:97-100.

440 Bartoletti R, Cai T, Nesi G, Roberta Girardi L, Baroni G, Dal Canto M: Loss of P16 expression and chromosome 9p21 LOH in predicting outcome of patients affected by superficial bladder cancer. J Surg Res 2007;143:422-427.

441 Ito T, Nishida N, Fukuda Y, Nishimura T, Komeda T, Nakao K: Alteration of the p14(ARF) gene and p53 status in human hepatocellular carcinomas. J Gastroenterol 2004;39:355-361.

442 Herath NI, Kew MC, Walsh MD, Young J, Powell LW, Leggett BA, MacDonald GA: Reciprocal relationship between methylation status and loss of heterozygosity at the p14(ARF) locus in Australian and South African hepatocellular carcinomas. J Gastroenterol Hepatol 2002;17:301-307.

443 Berggren P, Kumar R, Sakano S, Hemminki L, Wada T, Steineck G, Adolfsson J, Larsson P, Norming U, Wijkstrom H, Hemminki K: Detecting homozygous deletions in the CDKN2A(p16(INK4a))/ARF(p14(ARF)) gene in urinary bladder cancer using real-time quantitative PCR. Clin Cancer Res 2003;9:235-242.

444 Dominguez G, Silva J, Garcia JM, Silva JM, Rodriguez R, Munoz C, Chacon I, Sanchez R, Carballido J, Colas A, Espana P, Bonilla F: Prevalence of aberrant methylation of p14ARF over p16INK4a in some human primary tumors. Mutat Res 2003;530:9-17.

445 Dulaimi E, Uzzo RG, Greenberg RE, Al-Saleem T, Cairns P: Detection of bladder cancer in urine by a tumor suppressor gene hypermethylation panel. Clin Cancer Res 2004;10:1887-1893. 


\section{Cellular Physiology Cell Physiol Biochem 2018;51:2647-2693 \begin{tabular}{ll|l} 
and Biochemistry Published onlIne: 12 December 2018 & $\begin{array}{l}\text { (c) } 2018 \text { The Author(s). Published by S. Karger AG, Basel } \\
\text { www.karger.com/cpb }\end{array}$ \\
\hline
\end{tabular}}

Wang et al.: Loss of Tumor Suppressor Genes Function

446 Weng MT, Tung TH, Lee JH, Wei SC, Lin HL, Huang YJ, Wong JM, Luo J, Sheu JC: Enhancer of rudimentary homolog regulates DNA damage response in hepatocellular carcinoma. Sci Rep 2015;5:9357.

-447 Bartkova J, Guldberg P, Gronbaek K, Koed K, Primdahl H, Moller K, Lukas J, Orntoft TF, Bartek J: Aberrations of the Chk2 tumour suppressor in advanced urinary bladder cancer. Oncogene 2004;23:8545-8551.

448 Bartkova J, Horejsi Z, Koed K, Kramer A, Tort F, Zieger K, Guldberg P, Sehested M, Nesland JM, Lukas C, Orntoft T, Lukas J, Bartek J: DNA damage response as a candidate anti-cancer barrier in early human tumorigenesis. Nature 2005;434:864-870.

449 Wang SP, Zhou HJ, Chen XP, Ren GY, Ruan XX, Zhang Y, Zhang RL, Chen J: Loss of expression of Kruppel-like factor 6 in primary hepatocellular carcinoma and hepatoma cell lines. J Exp Clin Cancer Res 2007;26:117124.

450 Kremer-Tal S, Reeves HL, Narla G, Thung SN, Schwartz M, Difeo A, Katz A, Bruix J, Bioulac-Sage P, Martignetti JA, Friedman SL: Frequent inactivation of the tumor suppressor Kruppel-like factor 6 (KLF6) in hepatocellular carcinoma. Hepatology 2004;40:1047-1052.

451 Boyault S, Herault A, Balabaud C, Zucman-Rossi J: Absence of KLF6 gene mutation in 71 hepatocellular carcinomas. Hepatology 2005;41:681-682; author reply 682-683.

452 Song J, Kim CJ, Cho YG, Kim SY, Nam SW, Lee SH, Yoo NJ, Lee JY, Park WS: Genetic and epigenetic alterations of the KLF6 gene in hepatocellular carcinoma. J Gastroenterol Hepatol 2006;21:1286-1289.

453 Aaltonen V, Bostrom PJ, Soderstrom KO, Hirvonen O, Tuukkanen J, Nurmi M, Laato M, Peltonen J: Urinary bladder transitional cell carcinogenesis is associated with down-regulation of NF1 tumor suppressor gene in vivo and in vitro. Am J Pathol 1999;154:755-765.

454 Oguzkan S, Terzi YK, Guler E, Derbent M, Agras PI, Saatci U, Ayter S: Two neurofibromatosis type 1 cases associated with rhabdomyosarcoma of bladder, one with a large deletion in the NF1 gene. Cancer Genet Cytogenet 2006;164:159-163.

455 Diaz-Cano SJ, Blanes A, Rubio J, Matilla A, Wolfe HJ: Molecular evolution and intratumor heterogeneity by topographic compartments in muscle-invasive transitional cell carcinoma of the urinary bladder. Lab Invest 2000;80:279-289.

456 Uchida T, Wada C, Ishida H, Egawa S, Ao T, Yokoyama E, Koshiba K: Infrequent involvement of mutations on neurofibromatosis type 1, H-ras, K-ras and N-ras in urothelial tumors. Urologia internationalis 1995;55:6367.

-457 Csepregi A, Rocken C, Hoffmann J, Gu P, Saliger S, Muller O, Schneider-Stock R, Kutzner N, Roessner A, Malfertheiner P, Ebert MP: APC promoter methylation and protein expression in hepatocellular carcinoma. J Cancer Res Clin Oncol 2008;134:579-589.

458 Kurahashi H, Takami K, Oue T, Kusafuka T, Okada A, Tawa A, Okada S, Nishisho I: Biallelic inactivation of the APC gene in hepatoblastoma. Cancer Res 1995;55:5007-5011.

459 Piao Z, Kim H, Jeon BK, Lee WJ, Park C: Relationship between loss of heterozygosity of tumor suppressor genes and histologic differentiation in hepatocellular carcinoma. Cancer 1997;80:865-872.

460 Ishizaki Y, Ikeda S, Fujimori M, Shimizu Y, Kurihara T, Itamoto T, Kikuchi A, Okajima M, Asahara T: Immunohistochemical analysis and mutational analyses of beta-catenin, Axin family and APC genes in hepatocellular carcinomas. Int J Oncol 2004;24:1077-1083.

-461 Lee S, Lee HJ, Kim JH, Lee HS, Jang JJ, Kang GH: Aberrant CpG island hypermethylation along multistep hepatocarcinogenesis. Am J Pathol 2003;163:1371-1378.

-462 Stoehr R, Krieg RC, Knuechel R, Hofstaedter F, Pilarsky C, Zaak D, Schmitt R, Hartmann A: No evidence for involvement of beta-catenin and APC in urothelial carcinomas. Int J Oncol 2002;20:905-911.

463 Miyamoto H, Shuin T, Ikeda I, Hosaka M, Kubota Y: Loss of heterozygosity at the p53, RB, DCC and APC tumor suppressor gene loci in human bladder cancer. J Urol 1996;155:1444-1447.

464 Maruyama R, Toyooka S, Toyooka KO, Harada K, Virmani AK, Zochbauer-Muller S, Farinas AJ, Vakar-Lopez F, Minna JD, Sagalowsky A, Czerniak B, Gazdar AF: Aberrant promoter methylation profile of bladder cancer and its relationship to clinicopathological features. Cancer Res 2001;61:8659-8663.

465 Ho DWH, Chan LK, Chiu YT, Xu IMJ, Poon RTP, Cheung TT, Tang CN, Tang VWL, Lo ILO, Lam PWY, Yau DTW, Li MX, Wong CM, Ng IOL: TSC1/2 mutations define a molecular subset of HCC with aggressive behaviour and treatment implication. Gut 2017;66:1496-1506.

466 Adachi H, Igawa M, Shiina H, Urakami S, Shigeno K, Hino 0: Human bladder tumors with 2-hit mutations of tumor suppressor gene TSC1 and decreased expression of p27. J Urol 2003;170:601-604. 


\section{Cellular Physiology Cell Physiol Biochem 2018;51:2647-2693

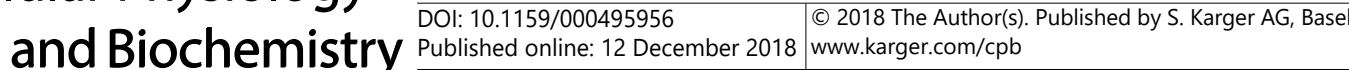

Wang et al.: Loss of Tumor Suppressor Genes Function

467 Hornigold N, Devlin J, Davies AM, Aveyard JS, Habuchi T, Knowles MA: Mutation of the 9q34 gene TSC1 in sporadic bladder cancer. Oncogene 1999;18:2657-2661.

468 van Tilborg AA, de Vries A, Zwarthoff EC: The chromosome 9q genes TGFBR1, TSC1, and ZNF189 are rarely mutated in bladder cancer. J Pathol 2001;194:76-80.

469 Nishida N, Nagasaka T, Nishimura T, Ikai I, Boland CR, Goel A: Aberrant methylation of multiple tumor suppressor genes in aging liver, chronic hepatitis, and hepatocellular carcinoma. Hepatology 2008;47:908918.

-470 Brait M, Begum S, Carvalho AL, Dasgupta S, Vettore AL, Czerniak B, Caballero OL, Westra WH, Sidransky D, Hoque MO: Aberrant promoter methylation of multiple genes during pathogenesis of bladder cancer. Cancer Epidemiol Biomarkers Prev 2008;17:2786-2794.

471 Wani Y, Notohara K, Tsukayama C, Okada S: Reduced expression of hMLH1 and hMSH2 gene products in high-grade hepatocellular carcinoma. Acta medica Okayama 2001;55:65-71.

472 Macdonald GA, Greenson JK, Saito K, Cherian SP, Appelman HD, Boland CR: Microsatellite instability and loss of heterozygosity at DNA mismatch repair gene loci occurs during hepatic carcinogenesis. Hepatology 1998;28:90-97.

473 Yano M, Hamatani K, Eguchi H, Hirai Y, MacPhee DG, Sugino K, Dohi K, Itamoto T, Asahara T: Prognosis in patients with hepatocellular carcinoma correlates to mutations of p53 and/or hMSH2 genes. Eur J Cancer 2007;43:1092-1100.

474 Yano M, Asahara T, Dohi K, Mizuno T, Iwamoto KS, Seyama T: Close correlation between a p53 or hMSH2 gene mutation in the tumor and survival of hepatocellular carcinoma patients. Int J Oncol 1999;14:447451.

475 Zhang CJ, Li HM, Yau LM, Suen KW, Zhou GY, Yu F, Liew CT: [Methylation of mismatch repair gene (MMR) in primary hepatocellular carcinoma]. Zhonghua bing li xue za zhi = Chinese Journal of Pathology 2004;33:433-436.

476 Catto JW, Xinarianos G, Burton JL, Meuth M, Hamdy FC: Differential expression of hMLH1 and hMSH2 is related to bladder cancer grade, stage and prognosis but not microsatellite instability. Int J Cancer 2003;105:484-490.

477 Kassem HS, Varley JM, Hamam SM, Margison GP: Immunohistochemical analysis of expression and allelotype of mismatch repair genes (hMLH1 and hMSH2) in bladder cancer. British J Cancer 2001;84:321328.

478 Joost P, Therkildsen C, Dominguez-Valentin M, Jonsson M, Nilbert M: Urinary Tract Cancer in Lynch Syndrome; Increased Risk in Carriers of MSH2 Mutations. Urology 2015;86:1212-1217.

479 Rubio J, Blanes A, Sanchez-Carrillo JJ, Diaz-Cano SJ: Microsatellite abnormalities and somatic downregulation of mismatch repair characterize nodular-trabecular muscle-invasive urothelial carcinoma of the bladder. Histopathology 2007;51:458-467.

-480 Abbosh PH, Wang M, Eble JN, Lopez-Beltran A, Maclennan GT, Montironi R, Zheng S, Pan CX, Zhou H, Cheng L: Hypermethylation of tumor-suppressor gene $\mathrm{CpG}$ islands in small-cell carcinoma of the urinary bladder. Modern Pathol 2008;21:355-362.

481 Rubio-Del-Campo A, Salinas-Sanchez AS, Sanchez-Sanchez F, Gimenez-Bachs JM, Donate-Moreno MJ, Pastor-Navarro H, Carrion-Lopez P, Escribano J: Implications of mismatch repair genes hMLH1 and hMSH2 in patients with sporadic renal cell carcinoma. BJU international 2008;102:504-509.

482 Wu SK, Wang BJ, Yang Y, Feng XH, Zhao XP, Yang DL: Expression of PTEN, PPM1A and P-Smad2 in hepatocellular carcinomas and adjacent liver tissues. World J Gastroenterol 2007;13:4554-4559.

483 Tsuruta H, Kishimoto H, Sasaki T, Horie Y, Natsui M, Shibata Y, Hamada K, Yajima N, Kawahara K, Sasaki M, Tsuchiya N, Enomoto K, Mak TW, Nakano T, Habuchi T, Suzuki A: Hyperplasia and carcinomas in Ptendeficient mice and reduced PTEN protein in human bladder cancer patients. Cancer Res 2006;66:83898396.

484 Barbier-Torres L, Delgado TC, Garcia-Rodriguez JL, Zubiete-Franco I, Fernandez-Ramos D, Buque X, Cano A, Gutierrez-de Juan V, Fernandez-Dominguez I, Lopitz-Otsoa F, Fernandez-Tussy P, Boix L, Bruix J, Villa E, Castro A, Lu SC, Aspichueta P, Xirodimas D, Varela-Rey M, Mato JM, Beraza N, Martinez-Chantar ML: Stabilization of LKB1 and Akt by neddylation regulates energy metabolism in liver cancer. Oncotarget 2015;6:2509-2523.

-485 Kim CJ, Cho YG, Park JY, Kim TY, Lee JH, Kim HS, Lee JW, Song YH, Nam SW, Lee SH, Yoo NJ, Lee JY, Park WS: Genetic analysis of the LKB1/STK11 gene in hepatocellular carcinomas. Eur J Cancer 2004;40:136-141. 


\section{Cellular Physiology Cell Physiol Biochem 2018;51:2647-2693 \begin{tabular}{ll|l} 
DOl: 10.1159/000495956 & O 2018 The Author(s). Published by S. Karger AG, Basel \\
and Biochemistry & Published online: 12 December 2018 www.karger.com/cpb
\end{tabular}}

Wang et al.: Loss of Tumor Suppressor Genes Function

486 Chen H, Zhang T, Sheng Y, Zhang C, Peng Y, Wang X, Zhang C: Methylation Profiling of Multiple Tumor Suppressor Genes in Hepatocellular Carcinoma and the Epigenetic Mechanism of 30ST2 Regulation. J Cancer 2015;6:740-749.

487 Tigli H, Seven D, Tunc M, Sanli O, Basaran S, Ulutin T, Buyru N: LKB1 mutations and their correlation with LKB1 and Rheb expression in bladder cancer. Mol Carcinogen 2013;52:660-665.

488 Paik SY, Park YN, Kim H, Park C: Expression of transforming growth factor-beta1 and transforming growth factor-beta receptors in hepatocellular carcinoma and dysplastic nodules. Modern Pathol 2003;16:86-96.

489 McGarvey TW, Tait E, Tomaszewski JE, Malkowicz SB: Expression of Transforming Growth Factor-beta Receptors and Related Cell-Cycle Components in Transitional-Cell Carcinoma of the Bladder. Mol Urol 1999;3:371-380.

490 Chen T, Jackson C, Costello B, Singer N, Colligan B, Douglass L, Pemberton J, Deddens J, Graff JR, Carter $\mathrm{JH}$ : An intronic variant of the TGFBR1 gene is associated with carcinomas of the kidney and bladder. Int J Cancer 2004;112:420-425.

491 Salvucci M, Lemoine A, Saffroy R, Azoulay D, Lepere B, Gaillard S, Bismuth H, Reynes M, Debuire B: Microsatellite instability in European hepatocellular carcinoma. Oncogene 1999;18:181-187.

-492 Torbenson M, Marinopoulos S, Dang DT, Choti M, Ashfaq R, Maitra A, Boitnott J, Wilentz RE: Smad4 overexpression in hepatocellular carcinoma is strongly associated with transforming growth factor beta II receptor immunolabeling. Hum Pathol 2002;33:871-876.

493 Yakicier MC, Irmak MB, Romano A, Kew M, Ozturk M: Smad2 and Smad4 gene mutations in hepatocellular carcinoma. Oncogene 1999;18:4879-4883.

-494 Kawate S, Takenoshita S, Ohwada S, Mogi A, Fukusato T, Makita F, Kuwano H, Morishita Y: Mutation analysis of transforming growth factor beta type II receptor, Smad2, and Smad4 in hepatocellular carcinoma. Int J Oncol 1999;14:127-131.

-495 Fan Z, Zhang J, Bai J: [Deletion mapping of chromosome 18q and Smad proteins expression analysis in urinary bladder carcinomas]. Zhonghua zhong liu za zhi [Chinese journal of oncology] 2001;23:135-137.

-496 Sinik Z, Alkibay T, Ataoglu O, Biri H, Sozen S, Deniz N, Karaoglan U, Bozkirli I: Nuclear p53 overexpression in bladder, prostate, and renal carcinomas. Int J Urology 1997;4:546-551.

497 Brooks JD, Bova GS, Marshall FF, Isaacs WB: Tumor suppressor gene allelic loss in human renal cancers. J Urol 1993;150:1278-1283.

498 Reiter RE, Anglard P, Liu S, Gnarra JR, Linehan WM: Chromosome 17p deletions and p53 mutations in renal cell carcinoma. Cancer Res 1993;53:3092-3097.

499 Uchida T, Wada C, Shitara T, Egawa S, Mashimo S, Koshiba K: Infrequent involvement of p53 mutations and loss of heterozygosity of 17p in the tumorigenesis of renal cell carcinoma. J Urol 1993;150:1298-1301.

500 Torigoe S, Shuin T, Kubota Y, Horikoshi T, Danenberg K, Danenberg PV: p53 gene mutation in primary human renal cell carcinoma. Oncol Res 1992;4:467-472.

501 Jones PA, Laird PW: Cancer epigenetics comes of age. Nat Genet 1999;21:163-167.

502 Brooks JD, Bova GS, Ewing CM, Piantadosi S, Carter BS, Robinson JC, Epstein JI, Isaacs WB: An uncertain role for p53 gene alterations in human prostate cancers. Cancer Res 1996;56:3814-3822.

503 Macera MJ, Godec CJ, Sharma N, Verma RS: Loss of heterozygosity of the TP53 tumor suppressor gene and detection of point mutations by the non-isotopic RNAse cleavage assay in prostate cancer. Cancer Genet Cytogenet 1999;108:42-47.

504 Fan K, Dao DD, Schutz M, Fink LM: Loss of heterozygosity and overexpression of p53 gene in human primary prostatic adenocarcinoma. Diagnostic molecular pathology, part B 1994;3:265-270.

-505 Richardson RB: p53 mutations associated with aging-related rise in cancer incidence rates. Cell cycle 2013;12:2468-2478.

506 Maruschke M, Thur S, Kundt G, Nizze H, Hakenberg OW: Immunohistochemical expression of retinoblastoma protein and p16 in renal cell carcinoma. Urologia Internationalis 2011;86:60-67.

507 Suzuki Y, Tamura G, Maesawa C, Fujioka T, Kubo T, Satodate R: Analysis of genetic alterations in renal cell carcinoma using the polymerase chain reaction. Virchows Archiv 1994;425:335.

508 Dalgliesh GL, Furge K, Greenman C, Chen L, Bignell G, Butler A, Davies H, Edkins S, Hardy C, Latimer C, Teague J, Andrews J, Barthorpe S, Beare D, Buck G, Campbell PJ, Forbes S, Jia M, Jones D, Knott H et al.: Systematic sequencing of renal carcinoma reveals inactivation of histone modifying genes. Nature 2010;463:360-363. 


\section{Cellular Physiology Cell Physiol Biochem 2018;51:2647-2693

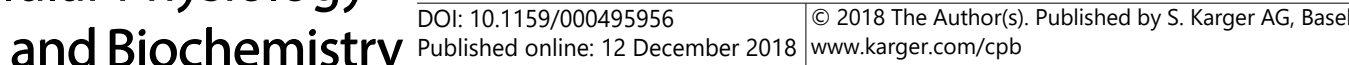

Wang et al.: Loss of Tumor Suppressor Genes Function

509 Phillips SM, Barton CM, Lee SJ, Morton DG, Wallace DM, Lemoine NR, Neoptolemos JP: Loss of the retinoblastoma susceptibility gene (RB1) is a frequent and early event in prostatic tumorigenesis. British J Cancer 1994;70:1252-1257.

510 Cooney KA, Wetzel JC, Merajver SD, Macoska JA, Singleton TP, Wojno KJ: Distinct regions of allelic loss on 13q in prostate cancer. Cancer Res 1996;56:1142-1145.

-511 Safran M, Dalah I, Alexander J, Rosen N, Iny Stein T, Shmoish M, Nativ N, Bahir I, Doniger T, Krug H, SirotaMadi A, Olender T, Golan Y, Stelzer G, Harel A, Lancet D: GeneCards Version 3: the human gene integrator. Database : the journal of biological databases and curation 2010;2010:baq020.

-512 Kubota Y, Fujinami K, Uemura H, Dobashi Y, Miyamoto H, Iwasaki Y, Kitamura H, Shuin T: Retinoblastoma gene mutations in primary human prostate cancer. The Prostate 1995;27:314-320.

513 Konishi N, Nakamura M, Kishi M, Nishimine M, Ishida E, Shimada K: DNA hypermethylation status of multiple genes in prostate adenocarcinomas. Jpn J Cancer Res : Gann 2002;93:767-773.

514 Vidaurreta M, Maestro ML, Sanz-Casla MT, Maestro C, Rafael S, Veganzones S, Moreno J, Blanco J, Silmi A, Arroyo M: Inactivation of p16 by CpG hypermethylation in renal cell carcinoma. Urologic Oncol 2008;26:239-245.

515 Cairns P, Mao L, Merlo A, Lee DJ, Schwab D, Eby Y, Tokino K, van der Riet P, Blaugrund JE, Sidransky D: Rates of p16 (MTS1) mutations in primary tumors with 9p loss. Science 1994;265:415-417.

516 Dulaimi E, Ibanez de Caceres I, Uzzo RG, Al-Saleem T, Greenberg RE, Polascik TJ, Babb JS, Grizzle WE, Cairns P: Promoter hypermethylation profile of kidney cancer. Clin Cancer Res 2004;10:3972-3979.

517 Hoque MO, Begum S, Topaloglu O, Jeronimo C, Mambo E, Westra WH, Califano JA, Sidransky D: Quantitative detection of promoter hypermethylation of multiple genes in the tumor, urine, and serum DNA of patients with renal cancer. Cancer Res 2004;64:5511-5517.

518 Ameri A, Alidoosti A, Hosseini SY, Parvin M, Emranpour MH, Taslimi F, Salehi E, Fadavip P: Prognostic Value of Promoter Hypermethylation of Retinoic Acid Receptor Beta (RARB) and CDKN2 (p16/MTS1) in Prostate Cancer. Chinese journal of cancer research = Chung-kuo yen cheng yen chiu 2011;23:306-311.

519 Kawada Y, Nakamura M, Ishida E, Shimada K, Oosterwijk E, Uemura H, Hirao Y, Chul KS, Konishi N: Aberrations of the p14(ARF) and p16(INK4a) genes in renal cell carcinomas. Jpn J Cancer Res Gann 2001;92:1293-1299.

520 Kasahara T, Bilim V, Hara N, Takahashi K, Tomita Y: Homozygous deletions of the INK4a/ARF locus in renal cell cancer. Anticancer Res 2006;26:4299-4305.

521 Konishi N, Nakamura M, Kishi M, Nishimine M, Ishida E, Shimada K: Heterogeneous methylation and deletion patterns of the INK4a/ARF locus within prostate carcinomas. Am J Pathol 2002;160:1207-1214.

522 Nguyen TT, Nguyen CT, Gonzales FA, Nichols PW, Yu MC, Jones PA: Analysis of cyclin-dependent kinase inhibitor expression and methylation patterns in human prostate cancers. The Prostate 2000;43:233-242.

523 Cybulski C, Wokolorczyk D, Huzarski T, Byrski T, Gronwald J, Gorski B, Debniak T, Masojc B, Jakubowska A, Gliniewicz B, Sikorski A, Stawicka M, Godlewski D, Kwias Z, Antczak A, Krajka K, Lauer W, Sosnowski $\mathrm{M}$, Sikorska-Radek $\mathrm{P}$, Bar $\mathrm{K}$ et al.: A large germline deletion in the Chek2 kinase gene is associated with an increased risk of prostate cancer. J Med Genet2006;43:863-866.

524 Wagenius M, Borg A, Johansson L, Giwercman A, Bratt O: CHEK2*1100delC is not an important high-risk gene in families with hereditary prostate cancer in southern Sweden. Scandinavian journal of urology and nephrology 2006;40:23-25.

525 Chen YB, Xu J, Skanderup AJ, Dong Y, Brannon AR, Wang L, Won HH, Wang PI, Nanjangud GJ, Jungbluth AA, Li W, Ojeda V, Hakimi AA, Voss MH, Schultz N, Motzer RJ, Russo P, Cheng EH, Giancotti FG, Lee W, Berger MF, Tickoo SK, Reuter VE, Hsieh JJ: Molecular analysis of aggressive renal cell carcinoma with unclassified histology reveals distinct subsets. Nat Commun 2016;7:13131.

526 Chen C, Hyytinen ER, Sun X, Helin HJ, Koivisto PA, Frierson HF, Jr., Vessella RL, Dong JT: Deletion, mutation, and loss of expression of KLF6 in human prostate cancer. Am J Pathol 2003;162:1349-1354.

527 Chiam K, Ryan NK, Ricciardelli C, Day TK, Buchanan G, Ochnik AM, Murti K, Selth LA, Australian Prostate Cancer B, Butler LM, Tilley WD, Bianco-Miotto T: Characterization of the prostate cancer susceptibility gene KLF6 in human and mouse prostate cancers. The Prostate 2013;73:182-193.

528 Narla G, Heath KE, Reeves HL, Li D, Giono LE, Kimmelman AC, Glucksman MJ, Narla J, Eng FJ, Chan AM, Ferrari AC, Martignetti JA, Friedman SL: KLF6, a candidate tumor suppressor gene mutated in prostate cancer. Science 2001;294:2563-2566. 
529 Pecina-Slaus N, Pavelic K, Pavelic J: Loss of heterozygosity and protein expression of APC gene in renal cell carcinomas. J Mol Med 1999;77:446-453.

530 Pecina SN, Gall-TroSelj K, M SL, Radic K, NikuSeva-Martic T, Pavelic K: Genetic changes of the E-cadherin and APC tumour suppressor genes in clear cell renal cell carcinoma. Pathology 2004;36:145-151.

-531 Brewster SF, Browne S, Brown KW: Somatic allelic loss at the DCC, APC, nm23-H1 and p53 tumor suppressor gene loci in human prostatic carcinoma. J Urol 1994;151:1073-1077.

532 Watanabe M, Kakiuchi H, Kato H, Shiraishi T, Yatani R, Sugimura T, Nagao M: APC gene mutations in human prostate cancer. Jpn J Clin Oncol 1996;26:77-81.

533 Kang GH, Lee S, Lee HJ, Hwang KS: Aberrant CpG island hypermethylation of multiple genes in prostate cancer and prostatic intraepithelial neoplasia. J Pathol 2004;202:233-240.

534 Parry L, Maynard JH, Patel A, Clifford SC, Morrissey C, Maher ER, Cheadle JP, Sampson JR: Analysis of the TSC1 and TSC2 genes in sporadic renal cell carcinomas. British J Cancer 2001;85:1226-1230.

535 Dekel Y, Kugel V, Livne PM, Gal R, Koren R: DCC protein expression in clear cell renal cell carcinoma. BJU Int 2004;93:867-869.

536 Hirata H, Matsuyama H, Matsumoto H, Korenaga Y, Ohmi C, Sakano S, Yoshihiro S, Naito K: Deletion mapping of 18q in conventional renal cell carcinoma. Cancer genetics and cytogenetics 2005;163:101-105.

537 Gao X, Honn KV, Grignon D, Sakr W, Chen YQ: Frequent loss of expression and loss of heterozygosity of the putative tumor suppressor gene DCC in prostatic carcinomas. Cancer Res 1993;53:2723-2727.

538 MacGrogan D, Bookstein R: Tumour suppressor genes in prostate cancer. Sem Cancer Biol 1997;8:11-19.

539 Alanee S, Shah S, Murali R, Rau-Murthy R, Schrader KA, Offit K: Absence of loss of heterozygosity of BRCA1 in a renal tumor from a BRCA1 germline mutation carrier. Familial Cancer 2013;12:125-127.

540 Linja MJ, Porkka KP, Kang Z, Savinainen KJ, Janne OA, Tammela TL, Vessella RL, Palvimo JJ, Visakorpi T: Expression of androgen receptor coregulators in prostate cancer. Clin Cancer Res 2004;10:1032-1040.

541 Uchida T, Wang C, Sato T, Gao J, Takashima R, Irie A, Ohori M, Koshiba K: BRCA1 gene mutation and loss of heterozygosity on chromosome 17q21 in primary prostate cancer. Int J Cancer 1999;84:19-23.

542 Sinclair CS, Berry R, Schaid D, Thibodeau SN, Couch FJ: BRCA1 and BRCA2 have a limited role in familial prostate cancer. Cancer Res 2000;60:1371-1375.

543 Rabiau N, Thiam MO, Satih S, Guy L, Kemeny JL, Boiteux JP, Fontana L, Bignon YJ, Bernard-Gallon D: Methylation analysis of BRCA1, RASSF1, GSTP1 and EPHB2 promoters in prostate biopsies according to different degrees of malignancy. In vivo 2009;23:387-391.

544 Ehsani L, Osunkoya AO: Expression of MLH1 and MSH2 in urothelial carcinoma of the renal pelvis. Tumour Biol 2014;35:8743-8747.

545 Baiyee D, Banner B: Mismatch repair genes in renal cortical neoplasms. Hum Pathol 2006;37:185-189.

546 Strom SS, Spitz MR, Yamamura Y, Babaian RJ, Scardino PT, Wei Q: Reduced expression of hMSH2 and hMLH1 and risk of prostate cancer: a case-control study. The Prostate 2001;47:269-275.

-547 Rosty C, Walsh MD, Lindor NM, Thibodeau SN, Mundt E, Gallinger S, Aronson M, Pollett A, Baron JA, Pearson S, Clendenning M, Walters RJ, Nagler BN, Crawford WJ, Young JP, Winship I, Win AK, Hopper JL, Jenkins MA, Buchanan DD: High prevalence of mismatch repair deficiency in prostate cancers diagnosed in mismatch repair gene mutation carriers from the colon cancer family registry. Fam Cancer 2014;13:573-582.

548 Pritchard CC, Morrissey C, Kumar A, Zhang X, Smith C, Coleman I, Salipante SJ, Milbank J, Yu M, Grady WM, Tait JF, Corey E, Vessella RL, Walsh T, Shendure J, Nelson PS: Complex MSH2 and MSH6 mutations in hypermutated microsatellite unstable advanced prostate cancer. Nat Commun 2014;5:4988.

549 Salinas-Sanchez AS, Rubio-del-Campo A, Sanchez-Sanchez F, Gimenez-Bachs JM, Donate-Moreno MJ, GarciaOlmo DC, Escribano-Martinez J: [Promoter hypermethylation status of the mismatch repair gene hMLH1 in patients with sporadic renal cell carcinoma]. Medicina Clinica 2006;126:452-454.

550 Hennenlotter J, Ohneseit PA, Simon P, Merseburger AS, Serth J, Kuehs U, Kramer M, Hartmann JT, Stenzl A, Kuczyk MA: PTEN and p27Kip1 are not downregulated in the majority of renal cell carcinomas-implications for Akt activation. Oncol Rep 2008;19:1141-1147.

551 Nojima D, Nakajima K, Li LC, Franks J, Ribeiro-Filho L, Ishii N, Dahiya R: CpG methylation of promoter region inactivates E-cadherin gene in renal cell carcinoma. Mol Carcinogen 2001;32:19-27.

552 Wikstrom P, Damber J, Bergh A: Role of transforming growth factor-beta1 in prostate cancer. Microscopy research and technique 2001;52:411-419. 


\section{Cellular Physiology Cell Physiol Biochem 2018;51:2647-2693 \begin{tabular}{l|l|l} 
and Biochemistry Published online: 12 December 2018 & $\begin{array}{l}\text { (c) } 2018 \text { The Author(s). Published by S. Karger AG, Basel } \\
\text { www.karger.com/cpb }\end{array}$ \\
\hline
\end{tabular}}

Wang et al.: Loss of Tumor Suppressor Genes Function

553 Copland JA, Luxon BA, Ajani L, Maity T, Campagnaro E, Guo H, LeGrand SN, Tamboli P, Wood CG: Genomic profiling identifies alterations in TGFbeta signaling through loss of TGFbeta receptor expression in human renal cell carcinogenesis and progression. Oncogene 2003;22:8053-8062.

554 Bhattacharyya N, Tao J, Klein EA, Banerjee S: Alterations of transforming growth factor beta receptor II, insulin growth factor receptor II genes in microsatellite unstable prostate carcinomas. Oncol Rep 2004;11:231-236.

555 Zhao H, Shiina H, Greene KL, Li LC, Tanaka Y, Kishi H, Igawa M, Kane CJ, Carroll P, Dahiya R: CpG methylation at promoter site -140 inactivates TGFbeta2 receptor gene in prostate cancer. Cancer 2005;104:44-52.

-556 Fukasawa H, Yamamoto T, Fujigaki Y, Misaki T, Ohashi N, Takayama T, Suzuki S, Mugiya S, Oda T, Uchida C, Kitagawa K, Hattori T, Hayashi H, Ozono S, Kitagawa M, Hishida A: Reduction of transforming growth factorbeta type II receptor is caused by the enhanced ubiquitin-dependent degradation in human renal cell carcinoma. Int J Cancer 2010;127:1517-1525.

-557 Popovic Hadzija M, Hrascan R, Bosnar MH, Zeljko Z, Hadzija M, Cadez J, Pavelic K, Kapitanovic S: Infrequent alteration of the DPC4 tumor suppressor gene in renal cell carcinoma. Urological research 2004;32:229235.

558 Horvath LG, Henshall SM, Kench JG, Turner JJ, Golovsky D, Brenner PC, O’Neill GF, Kooner R, Stricker PD, Grygiel JJ, Sutherland RL: Loss of BMP2, Smad8, and Smad4 expression in prostate cancer progression. The Prostate 2004;59:234-242.

559 MacGrogan D, Pegram M, Slamon D, Bookstein R: Comparative mutational analysis of DPC4 (Smad4) in prostatic and colorectal carcinomas. Oncogene 1997;15:1111-1114.

560 Aitchison AA, Veerakumarasivam A, Vias M, Kumar R, Hamdy FC, Neal DE, Mills IG: Promoter methylation correlates with reduced Smad4 expression in advanced prostate cancer. The Prostate 2008;68:661-674.

561 Park JH, Lee C, Suh JH, Chae JY, Moon KC: Nuclear expression of Smad proteins and its prognostic significance in clear cell renal cell carcinoma. Hum Pathol 2013;44:2047-2054.

562 Latil A, Pesche S, Valeri A, Fournier G, Cussenot O, Lidereau R: Expression and mutational analysis of the MADR2/Smad2 gene in human prostate cancer. The Prostate 1999;40:225-231.

563 Borresen-Dale AL: TP53 and breast cancer. Hum Mutat 2003;21:292-300.

564 Otis CN, Krebs PA, Albuquerque A, Quezado MM, San Juan X, Sobel ME, Merino MJ: Loss of heterozygosity of p53, BRCA1, VHL, and estrogen receptor genes in breast carcinoma: correlation with related protein products and morphologic features. Int J Surg Pathol 2002;10:237-245.

565 Thompson AM, Anderson TJ, Condie A, Prosser J, Chetty U, Carter DC, Evans HJ, Steel CM: p53 allele losses, mutations and expression in breast cancer and their relationship to clinico-pathological parameters. Int J Cancer 1992;50:528-532.

566 Chen LC, Neubauer A, Kurisu W, Waldman FM, Ljung BM, Goodson W, 3rd, Goldman ES, Moore D, 2nd, Balazs M, Liu E.: Loss of heterozygosity on the short arm of chromosome 17 is associated with high proliferative capacity and DNA aneuploidy in primary human breast cancer. Proc Natl Acad Sci U S A 1991;88:3847-3851.

567 Kang JH, Kim SJ, Noh DY, Park IA, Choe KJ, Yoo OJ, Kang HS: Methylation in the p53 promoter is a supplementary route to breast carcinogenesis: correlation between $\mathrm{CpG}$ methylation in the p53 promoter and the mutation of the $\mathrm{p} 53$ gene in the progression from ductal carcinoma in situ to invasive ductal carcinoma. Laboratory investigation 2001;81:573-579.

568 Schuijer M, Berns EM: TP53 and ovarian cancer. Hum Mutat 2003;21:285-291.

569 Salmena L, Shaw P, Fans I, McLaughlin, Rosen B, Risch H, Mitchell C, Sun P, Narod SA, Kotsopoulos J: Prognostic value of INPP4B protein immunohistochemistry in ovarian cancer. Eur J Gynaecological Oncol 2015;36:260-267.

570 Tsao SW, Mok CH, Oike K, Muto M, Goodman HM, Sheets EE, Berkowitz RS, Knapp RC, Lau CC: Involvement of p53 gene in the allelic deletion of chromosome 17p in human ovarian tumors. Anticancer Res 1991;11:1975-1982.

571 Phillips NJ, Ziegler MR, Radford DM, Fair KL, Steinbrueck T, Xynos FP, Donis-Keller H: Allelic deletion on chromosome 17p13.3 in early ovarian cancer. Cancer Res 1996;56:606-611.

572 McManus DT, Yap EP, Maxwell P, Russell SE, Toner PG, McGee JO: p53 expression, mutation, and allelic deletion in ovarian cancer. J Pathol 1994;174:159-168. 


\section{Cellular Physiology Cell Physiol Biochem 2018;51:2647-2693 \begin{tabular}{l|l|l} 
and Biochemistry Published onlIne: 12 December 2018 & $\begin{array}{l}\text { ○ 2018 The Author(s). Published by S. Karger AG, Basel } \\
\text { www.karger.com/cpb }\end{array}$ \\
\hline
\end{tabular}}

Wang et al.: Loss of Tumor Suppressor Genes Function

573 Kim YM, Lee SW, Chun SM, Kim DY, Kim JH, Kim KR, Kim YT, Nam JH, van Hummelen P, MacConaill LE, Hahn WC, Jang SJ: Analysis and comparison of somatic mutations in paired primary and recurrent epithelial ovarian cancer samples. PloS one 2014;9:e99451.

574 Chmelarova M, Krepinska E, Spacek J, Laco J, Beranek M, Palicka V: Methylation in the p53 promoter in epithelial ovarian cancer. Clin Translat Oncol 2013;15:160-163.

575 Varley JM, Armour J, Swallow JE, Jeffreys AJ, Ponder BA, T’Ang A, Fung YK, Brammar WJ, Walker RA: The retinoblastoma gene is frequently altered leading to loss of expression in primary breast tumours. Oncogene 1989;4:725-729.

576 Berge EO, Knappskog S, Lillehaug JR, Lonning PE: Alterations of the retinoblastoma gene in metastatic breast cancer. Clin Exp Metas 2011;28:319-326.

577 Bieche I, Lidereau R: Loss of heterozygosity at 13q14 correlates with RB1 gene underexpression in human breast cancer. Mol Carcinogen 2000;29:151-158.

578 Wang ZC, Lin M, Wei LJ, Li C, Miron A, Lodeiro G, Harris L, Ramaswamy S, Tanenbaum DM, Meyerson M, Iglehart JD, Richardson A: Loss of heterozygosity and its correlation with expression profiles in subclasses of invasive breast cancers. Cancer Res 2004;64:64-71.

579 Milea A, George SH, Matevski D, Jiang H, Madunic M, Berman HK, Gauthier ML, Gallie B, Shaw PA: Retinoblastoma pathway deregulatory mechanisms determine clinical outcome in high-grade serous ovarian carcinoma. Modern Pathol 2014;27:991-1001.

580 Liu Y, Heyman M, Wang Y, Falkmer U, Hising C, Szekely L, Einhorn S: Molecular analysis of the retinoblastoma gene in primary ovarian cancer cells. Int J Cancer 1994;58:663-667.

581 Cancer Genome Atlas Research N: Integrated genomic analyses of ovarian carcinoma. Nature 2011;474:609-615.

582 Zhang YB, Lu HX, Zhang XR, Qin LJ, Dong GL, Sun N, Zhang T: [The Methylation of p16 Gene Promoter in Carcinogenesis and Development of Breast Cancer]. Sichuan da xue xue bao Yi xue ban = Journal of Sichuan University Medical Science Edition 2015;46:409-412.

583 Silva J, Silva JM, Dominguez G, Garcia JM, Cantos B, Rodriguez R, Larrondo FJ, Provencio M, Espana P, Bonilla F: Concomitant expression of $\mathrm{p} 16 \mathrm{INK} 4 \mathrm{a}$ and $\mathrm{p} 14 \mathrm{ARF}$ in primary breast cancer and analysis of inactivation mechanisms. J Pathol 2003;199:289-297.

584 Bhagat R, Kumar SS, Vaderhobli S, Premalata CS, Pallavi VR, Ramesh G, Krishnamoorthy L: Epigenetic alteration of p16 and retinoic acid receptor beta genes in the development of epithelial ovarian carcinoma. Tumour Biol 2014;35:9069-9078.

-585 Makarla PB, Saboorian MH, Ashfaq R, Toyooka KO, Toyooka S, Minna JD, Gazdar AF, Schorge JO: Promoter hypermethylation profile of ovarian epithelial neoplasms. Clin Cancer Res 2005;11:5365-5369.

586 Silva J, Dominguez G, Silva JM, Garcia JM, Gallego I, Corbacho C, Provencio M, Espana P, Bonilla F: Analysis of genetic and epigenetic processes that influence p14ARF expression in breast cancer. Oncogene 2001;20:4586-4590.

587 Cabral VD, Cerski MR, Sa Brito IT, Kliemann LM: p14 expression differences in ovarian benign, borderline and malignant epithelial tumors. J Ovarian Res 2016;9:69.

-588 Teodoridis JM, Hall J, Marsh S, Kannall HD, Smyth C, Curto J, Siddiqui N, Gabra H, McLeod HL, Strathdee G, Brown R: CpG island methylation of DNA damage response genes in advanced ovarian cancer. Cancer Res 2005;65:8961-8967.

589 Yang HJ, Liu VW, Wang Y, Tsang PC, Ngan HY: Differential DNA methylation profiles in gynecological cancers and correlation with clinico-pathological data. BMC Cancer 2006;6:212.

-590 Staalesen V, Falck J, Geisler S, Bartkova J, Borresen-Dale AL, Lukas J, Lillehaug JR, Bartek J, Lonning PE: Alternative splicing and mutation status of CHEK2 in stage III breast cancer. Oncogene 2004;23:8535-8544.

591 Ribeiro-Silva A, Moutinho MA, Moura HB, Vale FR, Zucoloto S: Expression of checkpoint kinase 2 in breast carcinomas: correlation with key regulators of tumor cell proliferation, angiogenesis, and survival. Histol Histopathol 2006;21:373-382.

592 Sullivan A, Yuille M, Repellin C, Reddy A, Reelfs O, Bell A, Dunne B, Gusterson BA, Osin P, Farrell PJ, Yulug I, Evans A, Ozcelik T, Gasco M, Crook T: Concomitant inactivation of p53 and Chk2 in breast cancer. Oncogene 2002;21:1316-1324.

-593 Ingvarsson S, Sigbjornsdottir BI, Huiping C, Hafsteinsdottir SH, Ragnarsson G, Barkardottir RB, Arason A, Egilsson V, Bergthorsson JT: Mutation analysis of the CHK2 gene in breast carcinoma and other cancers. Breast Cancer Res 2002;4:R4. 


\section{Cellular Physiology Cell Physiol Biochem 2018;51:2647-2693

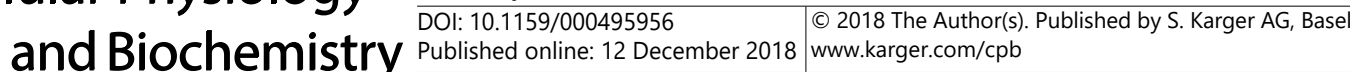

Wang et al.: Loss of Tumor Suppressor Genes Function

594 Miller CW, Ikezoe T, Krug U, Hofmann WK, Tavor S, Vegesna V, Tsukasaki K, Takeuchi S, Koeffler HP: Mutations of the CHK2 gene are found in some osteosarcomas, but are rare in breast, lung, and ovarian tumors. Genes Chromosomes Cancer 2002;33:17-21.

595 Ozdemir F, Koksal M, Ozmen V, Aydin I, Buyru N: Mutations and Kruppel-like factor 6 (KLF6) expression levels in breast cancer. Tumour Biol 2014;35:5219-5225.

596 Gehrau RC, D’Astolfo DS, Dumur CI, Bocco JL, Koritschoner NP: Nuclear expression of KLF6 tumor suppressor factor is highly associated with overexpression of ERBB2 oncoprotein in ductal breast carcinomas. PloS one 2010;5:e8929.

-597 DiFeo A, Narla G, Hirshfeld J, Camacho-Vanegas O, Narla J, Rose SL, Kalir T, Yao S, Levine A, Birrer MJ, Bonome T, Friedman SL, Buller RE, Martignetti JA: Roles of KLF6 and KLF6-SV1 in ovarian cancer progression and intraperitoneal dissemination. Clin Cancer Res 2006;12:3730-3739.

598 Guran S, Safali M: A case of neurofibromatosis and breast cancer: loss of heterozygosity of NF1 in breast cancer. Cancer Genet Cytogenet 2005;156:86-88.

599 Wallace MD, Pfefferle AD, Shen L, McNairn AJ, Cerami EG, Fallon BL, Rinaldi VD, Southard TL, Perou CM, Schimenti JC: Comparative oncogenomics implicates the neurofibromin 1 gene (NF1) as a breast cancer driver. Genetics 2012;192:385-396.

-600 Iyengar TD, Ng S, Lau CC, Welch WR, Bell DA, Berkowitz RS, Mok SC: Differential expression of NF1 type I and type II isoforms in sporadic borderline and invasive epithelial ovarian tumors. Oncogene 1999;18:257262.

601 Wertheim I, Tangir J, Muto MG, Welch WR, Berkowitz RS, Chen WY, Mok SC: Loss of heterozygosity of chromosome 17 in human borderline and invasive epithelial ovarian tumors. Oncogene 1996;12:21472153.

602 Ross JS, Ali SM, Wang K, Palmer G, Yelensky R, Lipson D, Miller VA, Zajchowski D, Shawver LK, Stephens PJ: Comprehensive genomic profiling of epithelial ovarian cancer by next generation sequencing-based diagnostic assay reveals new routes to targeted therapies. Gynecol Oncol 2013;130:554-559.

603 Foulkes WD, Englefield P, Campbell IG: Mutation analysis of RASK and the 'FLR exon' of NF1 in sporadic ovarian carcinoma. Eur J Cancer 1994;30A:528-530.

604 Ho KY, Kalle WH, Lo TH, Lam WY, Tang CM: Reduced expression of APC and DCC gene protein in breast cancer. Histopathology 1999;35:249-256.

605 Thompson AM, Morris RG, Wallace M, Wyllie AH, Steel CM, Carter DC: Allele loss from 5q21 (APC/MCC) and 18q21 (DCC) and DCC mRNA expression in breast cancer. British J Cancer 1993;68:64-68.

-606 Sarrio D, Moreno-Bueno G, Hardisson D, Sanchez-Estevez C, Guo M, Herman JG, Gamallo C, Esteller M, Palacios J: Epigenetic and genetic alterations of APC and CDH1 genes in lobular breast cancer: relationships with abnormal E-cadherin and catenin expression and microsatellite instability. Int J Cancer 2003;106:208215.

607 Kashiwaba M, Tamura G, Ishida M: Aberrations of the APC gene in primary breast carcinoma. J Cancer Res Clin Oncol 1994;120:727-731.

608 Zhang X, Li M, Zuo K, Li D, Ye M, Ding L, Cai H, Fu D, Fan Y, Lv Z: Upregulated miR-155 in papillary thyroid carcinoma promotes tumor growth by targeting APC and activating Wnt/beta-catenin signaling. J Clin Endocrinol Metab 2013;98:E1305-1313.

609 Shakeri H, Fakhrjou A, Nikanfar A, Mohaddes-Ardebili SM: Methylation Analysis of BRCA1 and APC in Breast Cancer and It's Relationship to Clinicopathological Features. Clin Lab2016;62:2333-2337.

610 Karbova E, Davidson B, Metodiev K, Trope CG, Nesland JM: Adenomatous polyposis coli (APC) protein expression in primary and metastatic serous ovarian carcinoma. Int J Surg Pathol 2002;10:175-180.

611 Tavassoli M, Steingrimsdottir H, Pierce E, Jiang X, Alagoz M, Farzaneh F, Campbell IG: Loss of heterozygosity on chromosome $5 q$ in ovarian cancer is frequently accompanied by TP53 mutation and identifies a tumour suppressor gene locus at 5q13.1-21. British J Cancer 1996;74:115-119.

612 Foulkes WD, Black DM, Stamp GW, Solomon E, Trowsdale J: Very frequent loss of heterozygosity throughout chromosome 17 in sporadic ovarian carcinoma. Int J Cancer 1993;54:220-225.

613 Allan GJ, Cottrell S, Trowsdale J, Foulkes WD: Loss of heterozygosity on chromosome 5 in sporadic ovarian carcinoma is a late event and is not associated with mutations in APC at 5q21-22. Hum Mutat 1994;3:283291. 


\section{Cellular Physiology Cell Physiol Biochem 2018;51:2647-2693 \begin{tabular}{l|l|l} 
and Biochemistry Published onlIne: I2 December 2018 & $\begin{array}{l}\text { ○ 2018 The Author(s). Published by S. Karger AG, Basel } \\
\text { www.karger.com/cpb }\end{array}$ \\
\hline
\end{tabular}}

Wang et al.: Loss of Tumor Suppressor Genes Function

614 Ab Mutalib NS, Syafruddin SE, Md Zain RR, Mohd Dali AZ, Mohd Yunos RI, Saidin S, Jamal R, Mokhtar NM: Molecular characterization of serous ovarian carcinoma using a multigene next generation sequencing cancer panel approach. BMC Res Notes 2014;7:805.

615 Bhagat R, Chadaga S, Premalata CS, Ramesh G, Ramesh C, Pallavi VR, Krishnamoorthy L: Aberrant promoter methylation of the RASSF1A and APC genes in epithelial ovarian carcinoma development. Cell Oncol 2012;35:473-479.

616 Jiang WG, Sampson J, Martin TA, Lee-Jones L, Watkins G, Douglas-Jones A, Mokbel K, Mansel RE: Tuberin and hamartin are aberrantly expressed and linked to clinical outcome in human breast cancer: the role of promoter methylation of TSC genes. Eur J Cancer 2005;41:1628-1636.

617 Koren R, Dekel Y, Sherman E, Weissman Y, Dreznik Z, Klein B, Gal R: The expression of DCC protein in female breast cancer. Breast Cancer Res Treat 2003;80:215-220.

618 Devilee P, van Vliet M, Kuipers-Dijkshoorn N, Pearson PL, Cornelisse CJ: Somatic genetic changes on chromosome 18 in breast carcinomas: is the DCC gene involved? Oncogene 1991;6:311-315.

619 Saegusa M, Machida D, Okayasu I: Loss of DCC gene expression during ovarian tumorigenesis: relation to tumour differentiation and progression. British J Cancer 2000;82:571-578.

620 Papanastasiou AD, Pampalakis G, Katsaros D, Sotiropoulou G: Netrin-1 overexpression is predictive of ovarian malignancies. Oncotarget 2011;2:363-367.

621 Milner BJ, Allan LA, Kelly KF, Cruickshank D, Hall M, Johnston A, Kitchener H, Parkin D, Haites N: Linkage studies with 17q and 18q markers in a breast/ovarian cancer family. Am J Hum Genet 1993;52:761-766.

622 Thompson ME, Jensen RA, Obermiller PS, Page DL, Holt JT: Decreased expression of BRCA1 accelerates growth and is often present during sporadic breast cancer progression. Nat Genet 1995;9:444-450.

623 Beckmann MW, Picard F, An HX, van Roeyen CR, Dominik SI, Mosny DS, Schnurch HG, Bender HG, Niederacher D: Clinical impact of detection of loss of heterozygosity of BRCA1 and BRCA2 markers in sporadic breast cancer. British J Cancer 1996;73:1220-1226.

624 Nasedkina TV, Gromyko OE, Emel'ianova MA, Ignatova EO, Kazubskaia TP, Portnoi SM, Zasedatelev AS, Liubchenko LN: [Genotyping of BRCA1, BRCA2 and CHEK2 germline mutations in Russian breast cancer patients using diagnostic biochips]. Molekuliarnaia Biologiia 2014;48:243-250.

625 Catteau A, Morris JR: BRCA1 methylation: a significant role in tumour development? Seminars in cancer biology 2002;12:359-371.

626 Wang C, Horiuchi A, Imai T, Ohira S, Itoh K, Nikaido T, Katsuyama Y, Konishi I: Expression of BRCA1 protein in benign, borderline, and malignant epithelial ovarian neoplasms and its relationship to methylation and allelic loss of the BRCA1 gene. J Pathol 2004;202:215-223.

627 Okada S, Tokunaga E, Kitao H, Akiyoshi S, Yamashita N, Saeki H, Oki E, Morita M, Kakeji Y, Maehara Y: Loss of heterozygosity at BRCA1 locus is significantly associated with aggressiveness and poor prognosis in breast cancer. Ann Surg Oncol 2012;19:1499-1507.

628 Murata H, Khattar NH, Gu L, Li GM: Roles of mismatch repair proteins hMSH2 and hMLH1 in the development of sporadic breast cancer. Cancer Lett 2005;223:143-150.

629 Naqvi RA, Hussain A, Deo SS, Kukreti H, Chauhan M, Sarin R, Saxena A, Asim M, Shukla NK, Husain SA, Pasha ST, Basir SF: Hypermethylation analysis of mismatch repair genes (hmlh1 and hmsh2) in locally advanced breast cancers in Indian women. Hum Pathol 2008;39:672-680.

630 Fu Q, Yao GY, Tang XL, Chen LR, Zheng ZX: [Microsatellite instability and allele-specific chromosome $3 p$ deletion in breast cancer and precancerous lesions]. Zhonghua zhong liu za zhi [Chinese journal of oncology] 2007;29:34-40.

631 Murata H, Khattar NH, Kang Y, Gu L, Li GM: Genetic and epigenetic modification of mismatch repair genes hMSH2 and hMLH1 in sporadic breast cancer with microsatellite instability. Oncogene 2002;21:5696-5703.

632 Ma L, Zhang J, Peng Z: [Expression of mismatch repair gene hMSH2 in human malignant ovarian tumors and its clinical significance]. Zhonghua fu chan ke za zhi 2000;35:291-293.

633 Fujita M, Enomoto T, Yoshino K, Nomura T, Buzard GS, Inoue M, Okudaira Y: Microsatellite instability and alterations in the hMSH2 gene in human ovarian cancer. Int J Cancer 1995;64:361-366.

-634 Song H, Cicek MS, Dicks E, Harrington P, Ramus SJ, Cunningham JM, Fridley BL, Tyrer JP, Alsop J, JimenezLinan M, Gayther SA, Goode EL, Pharoah PD: The contribution of deleterious germline mutations in BRCA1, BRCA2 and the mismatch repair genes to ovarian cancer in the population. Hum Mol Genet 2014;23:47034709 . 


\section{Cellular Physiology Cell Physiol Biochem 2018;51:2647-2693 \begin{tabular}{l|l|l} 
and Biochemistry Published onlIne: I2 December 2018 & $\begin{array}{l}\text { ○ 2018 The Author(s). Published by S. Karger AG, Basel } \\
\text { www.karger.com/cpb }\end{array}$ \\
\hline
\end{tabular}}

Wang et al.: Loss of Tumor Suppressor Genes Function

635 Alkam Y, Mitomi H, Nakai K, Himuro T, Saito T, Takahashi M, Arakawa A, Yao T, Saito M: Protein expression and methylation of DNA repair genes hMLH1, hMSH2, MGMT and BRCA1 and their correlation with clinicopathological parameters and prognosis in basal-like breast cancer. Histopathology 2013;63:713-725.

636 Scartozzi M, De Nictolis M, Galizia E, Carassai P, Bianchi F, Berardi R, Gesuita R, Piga A, Cellerino R, Porfiri E: Loss of hMLH1 expression correlates with improved survival in stage III-IV ovarian cancer patients. Eur J Cancer 2003;39:1144-1149.

637 Arzimanoglou, II, Hansen LL, Chong D, Li Z, Psaroudi MC, Dimitrakakis C, Jacovina AT, Shevchuk M, Reid L, Hajjar KA, Vassilaros S, Michalas S, Gilbert F, Chervenak FA, Barber HR: Frequent LOH at hMLH1, a highly variable SNP in hMSH3, and negligible coding instability in ovarian cancer. Anticancer Res 2002;22:969975.

638 Strathdee G, MacKean MJ, Illand M, Brown R: A role for methylation of the hMLH1 promoter in loss of hMLH1 expression and drug resistance in ovarian cancer. Oncogene 1999;18:2335-2341.

639 Bakarakos P, Theohari I, Nomikos A, Mylona E, Papadimitriou C, Dimopoulos AM, Nakopoulou L: Immunohistochemical study of PTEN and phosphorylated mTOR proteins in familial and sporadic invasive breast carcinomas. Histopathology 2010;56:876-882.

640 Tanic N, Milovanovic Z, Tanic N, Dzodic R, Juranic Z, Susnjar S, Plesinac-Karapandzic V, Tatic S, Dramicanin T, Davidovic R, Dimitrijevic B: The impact of PTEN tumor suppressor gene on acquiring resistance to tamoxifen treatment in breast cancer patients. Cancer Biol Ther 2012;13:1165-1174.

-641 Garcia JM, Silva J, Pena C, Garcia V, Rodriguez R, Cruz MA, Cantos B, Provencio M, Espana P, Bonilla F: Promoter methylation of the PTEN gene is a common molecular change in breast cancer. Genes Chromosomes Cancer 2004;41:117-124.

-642 Ho CM, Lin MC, Huang SH, Huang CJ, Lai HC, Chien TY, Chang SF: PTEN promoter methylation and LOH of 10q22-23 locus in PTEN expression of ovarian clear cell adenocarcinomas. Gynecol Oncol 2009;112:307313.

643 Schondorf T, Ebert MP, Hoffmann J, Becker M, Moser N, Pur S, Gohring UJ, Weisshaar MP: Hypermethylation of the PTEN gene in ovarian cancer cell lines. Cancer Lett 2004;207:215-220.

644 Shen Z, Wen XF, Lan F, Shen ZZ, Shao ZM: The tumor suppressor gene LKB1 is associated with prognosis in human breast carcinoma. Clin Cancer Res 2002;8:2085-2090.

645 Zhuang Z, Wang K, Cheng X, Qu X, Jiang B, Li Z, Luo J, Shao Z, Duan T: LKB1 inhibits breast cancer partially through repressing the Hedgehog signaling pathway. PloS one 2013;8:e67431.

646 Yang TL, Su YR, Huang CS, Yu JC, Lo YL, Wu PE, Shen CY: High-resolution 19p13.2-13.3 allelotyping of breast carcinomas demonstrates frequent loss of heterozygosity. Genes Chromosomes Cancer 2004;41:250-256.

647 Bignell GR, Barfoot R, Seal S, Collins N, Warren W, Stratton MR: Low frequency of somatic mutations in the LKB1/Peutz-Jeghers syndrome gene in sporadic breast cancer. Cancer Res 1998;58:1384-1386.

648 Fenton H, Carlile B, Montgomery EA, Carraway H, Herman J, Sahin F, Su GH, Argani P: LKB1 protein expression in human breast cancer. Appl Immunohisto Mol Morphol 2006;14:146-153.

649 Tanwar PS, Mohapatra G, Chiang S, Engler DA, Zhang L, Kaneko-Tarui T, Ohguchi Y, Birrer MJ, Teixeira JM: Loss of LKB1 and PTEN tumor suppressor genes in the ovarian surface epithelium induces papillary serous ovarian cancer. Carcinogenesis 2014;35:546-553.

650 Wang ZJ, Churchman M, Campbell IG, Xu WH, Yan ZY, McCluggage WG, Foulkes WD, Tomlinson IP: Allele loss and mutation screen at the Peutz-Jeghers (LKB1) locus (19p13.3) in sporadic ovarian tumours. British J Cancer 1999;80:70-72.

651 Li X, Schwartz MR, Ro J, Hamilton CR, Ayala AG, Truong LD, Zhai QJ: Diagnostic utility of E-cadherin and P120 catenin cocktail immunostain in distinguishing DCIS from LCIS. Int J Clinic Exp Pathol 2014;7:25512557.

652 Cho EY, Choi Y, Chae SW, Sohn JH, Ahn GH: Immunohistochemical study of the expression of adhesion molecules in ovarian serous neoplasms. Pathol Int 2006;56:62-70.

653 Buck MB, Fritz P, Dippon J, Zugmaier G, Knabbe C: Prognostic significance of transforming growth factor beta receptor II in estrogen receptor-negative breast cancer patients. Clin Cancer Res 2004;10:491-498.

654 Francis-Thickpenny KM, Richardson DM, van Ee CC, Love DR, Winship IM, Baguley BC, Chenevix-Trench G, Shelling AN: Analysis of the TGF beta functional pathway in epithelial ovarian carcinoma. British J Cancer 2001;85:687-691. 


\section{Cellular Physiology Cell Physiol Biochem 2018;51:2647-2693 and Biochemistry Published \begin{tabular}{l|l} 
DOI: 10.1159/000495956 & (c) 2018 The Author(s). Published by S. Karger AG, Basel \\
www.karger.com/cpb
\end{tabular}}

Wang et al.: Loss of Tumor Suppressor Genes Function

655 Wang D, Kanuma T, Mizunuma H, Takama F, Ibuki Y, Wake N, Mogi A, Shitara Y, Takenoshita S: Analysis of specific gene mutations in the transforming growth factor-beta signal transduction pathway in human ovarian cancer. Cancer Res 2000;60:4507-4512.

656 Lucke CD, Philpott A, Metcalfe JC, Thompson AM, Hughes-Davies L, Kemp PR, Hesketh R: Inhibiting mutations in the transforming growth factor beta type 2 receptor in recurrent human breast cancer. Cancer Res 2001;61:482-485.

657 Lynch MA, Nakashima R, Song H, DeGroff VL, Wang D, Enomoto T, Weghorst CM: Mutational analysis of the transforming growth factor beta receptor type II gene in human ovarian carcinoma. Cancer Res 1998;58:4227-4232.

658 Xie W, Mertens JC, Reiss DJ, Rimm DL, Camp RL, Haffty BG, Reiss M: Alterations of Smad signaling in human breast carcinoma are associated with poor outcome: a tissue microarray study. Cancer Res 2002;62:497505.

-659 Zhong D, Morikawa A, Guo L, Colpaert C, Xiong L, Nassar A, Chen C, Lamb N, Dong JT, Zhou W: Homozygous deletion of SMAD4 in breast cancer cell lines and invasive ductal carcinomas. Cancer Biol Ther 2006;5:601607.

660 Mabuchi Y, Yamoto M, Minami S, Umesaki N: Immunohistochemical localization of inhibin and activin subunits, activin receptors, and Smads in ovarian clear cell adenocarcinoma. Oncol Rep 2006;15:291-296.

-661 Lassus H, Salovaara R, Aaltonen LA, Butzow R: Allelic analysis of serous ovarian carcinoma reveals two putative tumor suppressor loci at 18q22-q23 distal to SMAD4, SMAD2, and DCC. Am J Pathol 2001;159:3542.

662 Takakura S, Okamoto A, Saito M, Yasuhara T, Shinozaki H, Isonishi S, Yoshimura T, Ohtake Y, Ochiai K, Tanaka T: Allelic imbalance in chromosome band 18q21 and SMAD4 mutations in ovarian cancers. Genes, Chromosomes Cancer 1999;24:264-271.

663 Tian F, DaCosta Byfield S, Parks WT, Yoo S, Felici A, Tang B, Piek E, Wakefield LM, Roberts AB: Reduction in Smad2/3 signaling enhances tumorigenesis but suppresses metastasis of breast cancer cell lines. Cancer Res 2003;63:8284-8292.

664 Hunt CR, Hale RJ, Buckley CH, Hunt J: p53 expression in carcinoma of the cervix. J Clin Pathol 1996;49:971974.

665 Halec G, Schmitt M, Dondog B, Sharkhuu E, Wentzensen N, Gheit T, Tommasino M, Kommoss F, Bosch FX, Franceschi S, Clifford G, Gissmann L, Pawlita M: Biological activity of probable/possible high-risk human papillomavirus types in cervical cancer. Int J Cancer 2013;132:63-71.

666 Kersemaekers AM, Hermans J, Fleuren GJ, van de Vijver MJ: Loss of heterozygosity for defined regions on chromosomes 3, 11 and 17 in carcinomas of the uterine cervix. British J Cancer 1998;77:192-200.

667 Busby-Earle RM, Steel CM, Williams AR, Cohen B, Bird CC: p53 mutations in cervical carcinogenesis--low frequency and lack of correlation with human papillomavirus status. British J Cancer 1994;69:732-737.

668 Lo KW, Mok CH, Chung G, Huang DP, Wong F, Chan M, Lee JC, Tsao SW: Presence of p53 mutation in human cervical carcinomas associated with HPV-33 infection. Anticancer Res 1992;12:1989-1994.

669 Jha AK, Nikbakht M, Jain V, Sehgal A, Capalash N, Kaur J: Promoter hypermethylation of p73 and p53 genes in cervical cancer patients among north Indian population. Mol Biol Rep 2012;39:9145-9157.

670 Stelloo E, Nout RA, Naves LC, Ter Haar NT, Creutzberg CL, Smit VT, Bosse T: High concordance of molecular tumor alterations between pre-operative curettage and hysterectomy specimens in patients with endometrial carcinoma. Gynecol Oncol 2014;133:197-204.

671 Sakuragi N, Salah-eldin AE, Watari H, Itoh T, Inoue S, Moriuchi T, Fujimoto S: Bax, Bcl-2, and p53 expression in endometrial cancer. Gynecol Oncol 2002;86:288-296.

672 Niwa K, Murase T, Morishita S, Hashimoto M, Itoh N, Tamaya T: p53 overexpression and mutation in endometrial carcinoma: inverted relation with estrogen and progesterone receptor status. Cancer Detect Prev 1999;23:147-154.

673 Semczuk A, Marzec B, Skomra D, Roessner A, Cybulski M, Rechberger T, Schneider-Stock R: Allelic loss at TP53 is not related to 553 protein overexpression in primary human endometrial carcinomas. Oncology 2005;69:317-325.

674 Tong D, Kucera E, Schuster E, Schmutzler RK, Swoboda H, Reinthaller A, Leodolter S, Zeillinger R: Loss of heterozygosity $(\mathrm{LOH})$ at p53 is correlated with $\mathrm{LOH}$ at BRCA1 and BRCA2 in various human malignant tumors. Int J Cancer 2000;88:319-322. 


\section{Cellular Physiology Cell Physiol Biochem 2018;51:2647-2693

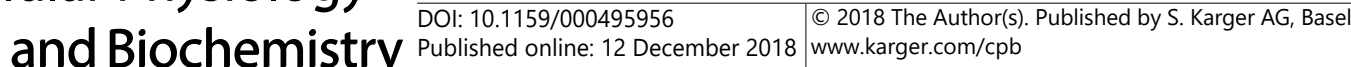

Wang et al.: Loss of Tumor Suppressor Genes Function

675 Kihana T, Hamada K, Inoue Y, Yano N, Iketani H, Murao S, Ukita M, Matsuura S: Mutation and allelic loss of the p53 gene in endometrial carcinoma. Incidence and outcome in 92 surgical patients. Cancer 1995;76:7278.

676 Risinger JI, Dent GA, Ignar-Trowbridge D, McLachlan JA, Tsao MS, Senterman M, Boyd J: p53 gene mutations in human endometrial carcinoma. Mol Carcinogen 1992;5:250-253.

-677 Honda T, Kato H, Imamura T, Gima T, Nishida J, Sasaki M, Hoshi K, Sato A, Wake N: Involvement of p53 gene mutations in human endometrial carcinomas. Int J Cancer 1993;53:963-967.

678 Chmelarova M, Kos S, Dvorakova E, Spacek J, Laco J, Ruszova E, Hrochova K, Palicka V: Importance of promoter methylation of GATA4 and TP53 genes in endometrioid carcinoma of endometrium. Clinical chemistry and laboratory medicine 2014;52:1229-1234.

679 Eltahir HA, Elhassan AM, Ibrahim ME: Contribution of retinoblastoma LOH and the p53 Arg/Pro polymorphism to cervical cancer. Mol Med Rep 2012;6:473-476.

680 Salcedo M, Taja L, Utrera D, Chavez P, Hidalgo A, Perez C, Benitez L, Castaneda C, Delgado R, Gariglio $\mathrm{P}$ : Changes in retinoblastoma gene expression during cervical cancer progression. Int J Exp Pathol 2002;83:275-286.

681 Park JS, Dong SM, Kim HS, Lee JY, Um SJ, Park IS, Kim SJ, Namkoong SE: Detection of p16 gene alteration in cervical cancer using tissue microdissection and LOH study. Cancer Lett 1999;136:101-108.

682 Semczuk A, Schneider-Stock R, Miturski R, Skomra D, Tomaszewski J, Roessner A, Jakowicki JA: RB protein expression in human endometrial carcinomas--an immunohistochemical study. Pathol Res Pract 2000;196:41-46.

683 Semczuk A, Marzec B, Roessner A, Jakowicki JA, Wojcierowski J, Schneider-Stock R: Loss of heterozygosity of the retinoblastoma gene is correlated with the altered $\mathrm{pRb}$ expression in human endometrial cancer. Virchows Archiv 2002;441:577-583.

-684 Wang JL, Zheng BY, Li XD, Nokelainen K, Angstrom T, Lindstrom MS, Wallin KL: p16INK4A and p14ARF expression pattern by immunohistochemistry in human papillomavirus-related cervical neoplasia. Modern Pathol 2005;18:629-637.

685 Tripathi A, Banerjee S, Roy A, Roychowdhury S, Panda CK: Alterations of the P16 gene in uterine cervical carcinoma from Indian patients. Int J Gynecol Cancer 2003;13:472-479.

686 Jha AK, Nikbakht M, Jain V, Capalash N, Kaur J: p16(INK4a) and p15(INK4b) gene promoter methylation in cervical cancer patients. Oncol Lett 2012;3:1331-1335.

687 Semczuk A, Boltze C, Marzec B, Szczygielska A, Roessner A, Schneider-Stock R: p16INK4A alterations are accompanied by aberrant protein immunostaining in endometrial carcinomas. J Cancer Res and Clinic Oncol 2003;129:589-596.

688 Salvesen HB, Kumar R, Stefansson I, Angelini S, MacDonald N, Smeds J, Jacobs IJ, Hemminki K, Das S, Akslen LA: Low frequency of BRAF and CDKN2A mutations in endometrial cancer. Int J Cancer 2005;115:930-934.

689 Zhang QY, Yi DQ, Zhou L, Zhang DH, Zhou TM: Status and significance of CpG island methylator phenotype in endometrial cancer. Gynecol Obstet Inves 2011;72:183-191.

690 Buchynska LG, Nesina IP, Kashuba EV: Different trends of p53, MDM2 and p14 ARF expression patterns in endometrial adenocarcinomas versus hyperplasia. Exp Oncol 2007;29:287-294.

691 Hashiguchi Y, Tsuda H, Nishimura S, Inoue T, Kawamura N, Yamamoto K: Relationship between HPV typing and the status of G2 cell cycle regulators in cervical neoplasia. Oncol Rep 2004;12:587-591.

-692 Tsuda H, Hashiguchi Y, Inoue T, Yamamoto K: Alteration of G2 cell cycle regulators occurs during carcinogenesis of the endometrium. Oncology 2003;65:159-166.

693 Marrero-Rodriguez D, Taniguchi-Ponciano K, Jimenez-Vega F, Romero-Morelos P, Mendoza-Rodriguez M, Mantilla A, Rodriguez-Esquivel M, Hernandez D, Hernandez A, Gomez-Gutierrez G, Munoz-Hernandez N, la Cruz HA, Vargas-Requena C, Diaz-Hernandez C, Serna-Reyna L, Meraz-Rios M, Bandala C, Ortiz-Leon J, Salcedo M: Kruppel-like factor 5 as potential molecular marker in cervical cancer and the KLF family profile expression. Tumour Biol 2014;35:11399-11407.

694 Myers AP, Filiaci VL, Zhang Y, Pearl M, Behbakht K, Makker V, Hanjani P, Zweizig S, Burke JJ, 2nd, Downey G, Leslie KK, Van Hummelen P, Birrer MJ, Fleming GF: Tumor mutational analysis of GOG248, a phase II study of temsirolimus or temsirolimus and alternating megestrol acetate and tamoxifen for advanced endometrial cancer (EC): An NRG Oncology/Gynecologic Oncology Group study. Gynecol Oncol 2016;141:43-48. 


\section{Cellular Physiology Cell Physiol Biochem 2018;51:2647-2693 and Biochemistry \begin{tabular}{l|l}
$\overline{\text { DOI: } 10.1159 / 000495956}$ & $\begin{array}{l}\text { (c) } 2018 \text { The Author(s). Published by S. Karger AG, Basel } \\
\text { www.karger.com/cpb }\end{array}$
\end{tabular}}

Wang et al.: Loss of Tumor Suppressor Genes Function

695 Song Y, Zhang C: Hydralazine inhibits human cervical cancer cell growth in vitro in association with APC demethylation and re-expression. Cancer Chemother Pharmacol2009;63:605-613.

696 Wistuba, II, Thomas B, Behrens C, Onuki N, Lindberg G, Albores-Saavedra J, Gazdar AF: Molecular abnormalities associated with endocrine tumors of the uterine cervix. Gynecol Oncol 1999;72:3-9.

697 Dong SM, Kim HS, Rha SH, Sidransky D: Promoter hypermethylation of multiple genes in carcinoma of the uterine cervix. Clin Cancer Res 2001;7:1982-1986.

698 Kariola R, Abdel-Rahman WM, Ollikainen M, Butzow R, Peltomaki P, Nystrom M: APC and beta-catenin protein expression patterns in HNPCC-related endometrial and colorectal cancers. Familial Cancer 2005;4:187-190.

699 Gray SE, Kay EW, Leader M, Mabruk M: Analysis of APC allelic imbalance/loss of heterozygosity and APC protein expression in cutaneous squamous cell carcinomas. Cancer Genomics Proteomic 2011;8:149-155.

700 Moreno-Bueno G, Hardisson D, Sanchez C, Sarrio D, Cassia R, Garcia-Rostan G, Prat J, Guo M, Herman JG, Matias-Guiu X, Esteller M, Palacios J: Abnormalities of the APC/beta-catenin pathway in endometrial cancer. Oncogene 2002;21:7981-7990.

-701 Tanwar PS, Kaneko-Tarui T, Zhang L, Tanaka Y, Crum CP, Teixeira JM: Stromal liver kinase B1 [STK11] signaling loss induces oviductal adenomas and endometrial cancer by activating mammalian Target of Rapamycin Complex 1. PLoS genetics 2012;8:e1002906.

702 Saegusa M, Okayasu I: DCC expression is related to mucinous differentiation but not changes in expression of p21(WAF1/Cip1) and p27Kip1, apoptosis, cell proliferation and human papillomavirus infection in uterine cervical adenocarcinomas. British J Cancer 1999;80:51-58.

-703 Kersemaekers AM, van de Vijver MJ, Kenter GG, Fleuren GJ: Genetic alterations during the progression of squamous cell carcinomas of the uterine cervix. Genes, Chromosomes Cancer 1999;26:346-354.

704 Patel DA, Rozek LS, Colacino JA, Van Zomeren-Dohm A, Ruffin MT, Unger ER, Dolinoy DC, Swan DC, Onyekwuluje J, DeGraffinreid CR, Paskett ED: Patterns of cellular and HPV 16 methylation as biomarkers for cervical neoplasia. J Virol Methods 2012;184:84-92.

705 Ronnett BM, Burks RT, Cho KR, Hedrick L: DCC genetic alterations and expression in endometrial carcinoma. Modern Pathol 1997;10:38-46.

706 Narayan G, Arias-Pulido H, Nandula SV, Basso K, Sugirtharaj DD, Vargas H, Mansukhani M, Villella J, Meyer L, Schneider A, Gissmann L, Durst M, Pothuri B, Murty VV: Promoter hypermethylation of FANCF: disruption of Fanconi Anemia-BRCA pathway in cervical cancer. Cancer Res 2004;64:2994-2997.

707 Krul EJ, Kersemaekers AM, Zomerdijk-Nooyen YA, Cornelisse CJ, Peters LA, Fleuren GJ: Different profiles of allelic losses in cervical carcinoma cases in Surinam and The Netherlands. Cancer 1999;86:997-1004.

708 Hecht JL, Konstantinopoulos PA, Awtrey CS, Soslow RA: Immunohistochemical loss of BRCA1 protein in uterine serous carcinoma. Int J Gynecol Pathol 2014;33:282-287.

709 Liu FS, Ho ES, Shih RT, Shih A: Mutational analysis of the BRCA1 tumor suppressor gene in endometrial carcinoma. Gynecol Oncol 1997;66:449-453.

710 Segev Y, Iqbal J, Lubinski J, Gronwald J, Lynch HT, Moller P, Ghadirian P, Rosen B, Tung N, Kim-Sing C, Foulkes WD, Neuhausen SL, Senter L, Singer CF, Karlan B, Ping S, Narod SA, Hereditary Breast Cancer Study G: The incidence of endometrial cancer in women with BRCA1 and BRCA2 mutations: an international prospective cohort study. Gynecol Oncol 2013;130:127-131.

-711 Nijhuis ER, Nijman HW, Oien KA, Bell A, ten Hoor KA, Reesink-Peters N, Boezen HM, Hollema H, van der Zee AG: Loss of MSH2 protein expression is a risk factor in early stage cervical cancer. J Clinical Pathol 2007;60:824-830.

712 Dowty JG, Win AK, Buchanan DD, Lindor NM, Macrae FA, Clendenning M, Antill YC, Thibodeau SN, Casey G, Gallinger S, Marchand LL, Newcomb PA, Haile RW, Young GP, James PA, Giles GG, Gunawardena SR, Leggett BA, Gattas M, Boussioutas A, Ahnen DJ, Baron JA, Parry S, Goldblatt J, Young JP, Hopper JL, Jenkins MA: Cancer risks for MLH1 and MSH2 mutation carriers. Hum Mutat 2013;34:490-497.

713 Long Q, Peng Y, Tang Z, Wu C: Role of endometrial cancer abnormal MMR protein in screening Lynchsyndrome families. Int J Clinic and Experimental Pathol 2014;7:7297-7303.

714 Miturski R, Postawski K, Semczuk A, Bogusiewicz M, Baranowski W, Jakowicki JA, Keith G: Global DNA methylation in relation to hMLH1 and hMSH2 protein immunoreactivity in sporadic human endometrial carcinomas. Int J Mol Med 2003;11:569-574. 
715 Peiro G, Diebold J, Lohse P, Ruebsamen H, Lohse P, Baretton GB, Lohrs U: Microsatellite instability, loss of heterozygosity, and loss of hMLH1 and hMSH2 protein expression in endometrial carcinoma. Hum Pathol 2002;33:347-354.

716 Kowalski LD, Mutch DG, Herzog TJ, Rader JS, Goodfellow PJ: Mutational analysis of MLH1 and MSH2 in 25 prospectively-acquired RER+ endometrial cancers. Genes, Chromosomes Cancer 1997;18:219-227.

717 Tao MH, Freudenheim JL: DNA methylation in endometrial cancer. Epigenetics 2010;5:491-498.

718 Ciavattini A, Piccioni M, Tranquilli AL, Filosa A, Pieramici T, Goteri G: Immunohistochemical expression of DNA mismatch repair (MMR) system proteins (hMLH1, hMSH2) in cervical preinvasive and invasive lesions. Pathol Res Pract 2005;201:21-25.

719 Spathis A, Aga E, Alepaki M, Chranioti A, Meristoudis C, Panayiotides I, Kassanos D, Karakitsos P: Promoter methylation of p16(INK4A), hMLH1, and MGMT in liquid-based cervical cytology samples compared with clinicopathological findings and HPV presence. Infect Dis Obstet Gyneco 2011;2011:927861.

720 Mills AM, Liou S, Ford JM, Berek JS, Pai RK, Longacre TA: Lynch syndrome screening should be considered for all patients with newly diagnosed endometrial cancer. Am J Surgical Pathol 2014;38:1501-1509.

721 Buchanan DD, Tan YY, Walsh MD, Clendenning M, Metcalf AM, Ferguson K, Arnold ST, Thompson BA, Lose FA, Parsons MT, Walters RJ, Pearson SA, Cummings M, Oehler MK, Blomfield PB, Quinn MA, Kirk JA, Stewart CJ, Obermair A, Young JP et al.: Tumor mismatch repair immunohistochemistry and DNA MLH1 methylation testing of patients with endometrial cancer diagnosed at age younger than 60 years optimizes triage for population-level germline mismatch repair gene mutation testing. J Clinic Oncol 2014;32:90-100.

722 El-Mansi MT, Williams AR: Evaluation of PTEN expression in cervical adenocarcinoma by tissue microarray. Int J Gynecol Cancer 2006;16:1254-1260.

723 Qi Q, Ling Y, Zhu M, Zhou L, Wan M, Bao Y, Liu Y: Promoter region methylation and loss of protein expression of PTEN and significance in cervical cancer. Biomed Rep 2014;2:653-658.

-724 Okon IS, Coughlan KA, Zou MH: Liver kinase B1 expression promotes phosphatase activity and abrogation of receptor tyrosine kinase phosphorylation in human cancer cells. J Biol Chem 2014;289:1639-1648.

725 Wingo SN, Gallardo TD, Akbay EA, Liang MC, Contreras CM, Boren T, Shimamura T, Miller DS, Sharpless NE, Bardeesy N, Kwiatkowski DJ, Schorge JO, Wong KK, Castrillon DH: Somatic LKB1 mutations promote cervical cancer progression. PloS one 2009;4:e5137.

726 Co NN, Iglesias D, Celestino J, Kwan SY, Mok SC, Schmandt R, Lu KH: Loss of LKB1 in high-grade endometrial carcinoma: LKB1 is a novel transcriptional target of p53. Cancer 2014;120:3457-3468.

727 Pathak S, Bhatla N, Singh N: Cervical cancer pathogenesis is associated with one-carbon metabolism. Mol Cell Biochem 2012;369:1-7.

728 Tanaka Y, Terai Y, Kawaguchi H, Fujiwara S, Yoo S, Tsunetoh S, Takai M, Kanemura M, Tanabe A, Ohmichi M: Prognostic impact of EMT (epithelial-mesenchymal-transition) -related protein expression in endometrial cancer. Cancer Biol Ther 2013;14:13-19.

-729 Risinger JI, Berchuck A, Kohler MF, Boyd J: Mutations of the E-cadherin gene in human gynecologic cancers. Nat Genet 1994;7:98-102.

730 Saito T, Nishimura M, Yamasaki H, Kudo R: Hypermethylation in promoter region of E-cadherin gene is associated with tumor dedifferention and myometrial invasion in endometrial carcinoma. Cancer 2003;97:1002-1009.

731 Soufla G, Sifakis S, Baritaki S, Zafiropoulos A, Koumantakis E, Spandidos DA: VEGF, FGF2, TGFB1 and TGFBR1 mRNA expression levels correlate with the malignant transformation of the uterine cervix. Cancer Lett 2005;221:105-118.

732 Chen T, de Vries EG, Hollema H, Yegen HA, Vellucci VF, Strickler HD, Hildesheim A, Reiss M: Structural alterations of transforming growth factor-beta receptor genes in human cervical carcinoma. Int J Cancer 1999;82:43-51.

733 Parekh TV, Gama P, Wen X, Demopoulos R, Munger JS, Carcangiu ML, Reiss M, Gold LI: Transforming growth factor beta signaling is disabled early in human endometrial carcinogenesis concomitant with loss of growth inhibition. Cancer Res 2002;62:2778-2790.

734 Nakashima R, Song H, Enomoto T, Murata Y, McClaid MR, Casto BC, Weghorst CM: Genetic alterations in the transforming growth factor receptor complex in sporadic endometrial carcinoma. Gene expression 1999;8:341-352.

735 Herzog CR, Crist KA, Sabourin CL, Kelloff GJ, Boone CW, Stoner GD, You M: Chromosome 3p tumorsuppressor gene alterations in cervical carcinomas. Mol Carcinogen 2001;30:159-168. 


\section{Cellular Physiology Cell Physiol Biochem 2018;51:2647-2693

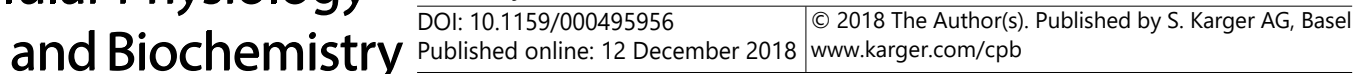

Wang et al.: Loss of Tumor Suppressor Genes Function

736 Sakaguchi J, Kyo S, Kanaya T, Maida Y, Hashimoto M, Nakamura M, Yamada K, Inoue M: Aberrant expression and mutations of TGF-beta receptor type II gene in endometrial cancer. Gynecol Oncol 2005;98:427-433.

-737 Baldus SE, Schwarz E, Lohrey C, Zapatka M, Landsberg S, Hahn SA, Schmidt D, Dienes HP, Schmiegel WH, Schwarte-Waldhoff I: Smad4 deficiency in cervical carcinoma cells. Oncogene 2005;24:810-819.

738 French D, Belleudi F, Mauro MV, Mazzetta F, Raffa S, Fabiano V, Frega A, Torrisi MR: Expression of HPV16 E5 down-modulates the TGFbeta signaling pathway. Mol Cancer 2013;12:38.

739 Zhou Y, Kato H, Shan D, Minami R, Kitazawa S, Matsuda T, Arima T, Barrett JC, Wake N: Involvement of mutations in the DPC4 promoter in endometrial carcinoma development. Mol Carcinogen 1999;25:64-72.

-740 Kozlowski L, Filipowski T, Rucinska M, Pepinski W, Janica J, Skawronska M, Poznanski J, Wojtukiewicz MZ: Loss of heterozygosity on chromosomes 2p, 3p, 18q21.3 and 11p15.5 as a poor prognostic factor in stage II and III (FIGO) cervical cancer treated by radiotherapy. Neoplasma 2006;53:440-443.

741 Bokhari AA, Lee LR, Raboteau D, Hamilton CA, Maxwell GL, Rodriguez GC, Syed V: Progesterone inhibits endometrial cancer invasiveness by inhibiting the TGF beta pathway. Cancer Prev Res 2014;7:1045-1055.

742 Piestrzeniewicz-Ulanska D, Brys M, Semczuk A, Rechberger T, Jakowicki JA, Krajewska WM: TGF-beta signaling is disrupted in endometrioid-type endometrial carcinomas. Gynecol Oncol 2004;95:173-180.

743 Toda T, Oku H, Khaskhely NM, Moromizato H, Ono I, Murata T: Analysis of microsatellite instability and loss of heterozygosity in uterine endometrial adenocarcinoma. Cancer Genet Cytogen 2001;126:120-127. 